2011

\title{
The History of Intellectual Property Taxation: Promoting Innovation and Other Intellectual Property Goals?
}

\author{
Xuan-Thao Nguyen \\ Southern Methodist University School of Law \\ Jeffrey A. Maine \\ University of Maine School of Law
}

Follow this and additional works at: http://digitalcommons.mainelaw.maine.edu/facultypublications

Part of the Intellectual Property Law Commons, and the Tax Law Commons

\section{Suggested Bluebook Citation}

Xuan-Thao Nguyen \& Jeffrey A. Maine, The History of Intellectual Property Taxation: Promoting Innovation and Other Intellectual Property Goals?, 64 SMU L. Rev. 101 (2011).

Available at: http://digitalcommons.mainelaw.maine.edu/faculty-publications/55 


\title{
THE HISTORY OF INTELLECTUAL PROPERTY TAXATION: PROMOTING INNOVATION AND OTHER INTELLECTUAL PROPERTY GOALS?
}

\author{
Xuan-Thao Nguyen ${ }^{*}$ \\ Jeffrey A. Maine ${ }^{* *}$
}

TABLE OF CONTENTS

I. Introduction

II. Historical Perspective: Applying Normative Tax Principles To Intellectual Property

A. Applying General Asset Capitalization to Research Costs

B. Applying Historic Depreciation Rules to Patent Acquisition Costs

C. Applying General Sale Principles to Patent Dispositions

III. Sources of Early Dissonance Between the Intellectual Property and Taxation Regimes

A. Accepting Intellectual Property as Property

B. Reconciling Substantive Differences Among Intellectual Properties

C. Establishing Significance of Tangible Medium Embodying Intellectual Property

IV. Three Goals of Specific Tax Rules Governing Intellectual Property

A. Supporting Intellectual Property Development and Economic Growth

1. Tax Incentives for Patent Development Activities

2. Tax Rules Applicable to Other Intellectual Property Development Activities

* Professor of Law, SMU Dedman School of Law. The Article was made possible with a summer grant from SMU Dedman School of Law and the Michael C. and Jacqueline M. Barrett Endowed Faculty Research Fund. Professor Nguyen thanks her co-author and friend Professor Maine for the endless excitement on the intersection of intellectual property and taxation. Special thanks to Erik Darwin Hille and Khai-Leif Nguyen-Hille for their love, patience, and support.

** Professor of Law \& Glassman Faculty Research Scholar, University of Maine School of Law. Professor Maine would like to thank Dean Peter Pitegoff for financially supporting his research on the intersection of intellectual property and taxation. He is grateful to Nathan Brown and Julie Welch for their tireless efforts in researching legislative history for this piece. Professor Maine gives special thanks to Professor Nguyen for the wonderful journey into intellectual property taxation. 
B. Eliminating Loopholes and Removing Tax Inequities

1. Tax Rules Governing Copyright Sales

2. Tax Rules for Trademark and Trade Name Expenditures

3. Tax Rules for Charitable Contributions of Intellectual Property

C. Simplifying Rules and Improving Clarity of Tax Results

1. Tax Rules for Patent Development and Assignments

2. Tax Rules for Trademark and Trade Name Dispositions

3. Tax Rules for Depreciating Intellectual Property Acquisition Costs

\section{The Current Tax Code and Intellectual Property: A Harmonious} Existence?

A. Supporting Intellectual Property's Innovation Goals

B. Supporting Intellectual Property Changes

\section{Conclusion}

\section{INTRODUCTION}

Intellectual property law serves a variety of societal goals, including fostering innovation and promoting economic and cultural development. While vital, however, intellectual property law alone cannot optimally achieve these widely shared goals. An important issue deserving scholarly attention concerns the proper role of the federal tax system in achieving intellectual property law's innovation objectives. Most tax theorists would argue that an ideal tax system should seek to minimize the social costs of taxation and avoid unnecessarily shaping economic behavior. But it might be decided that the tax system should depart from these tax principles to further innovation. Of course, tax rules that deliberately attempt to reward creative process and further innovation must provide certainty, clarity, and dependability necessary for compliance with, and sound administration of, the law. To do that, the rules must necessarily recognize changes in innovation and reflect the realities of today's economy.

The Income Tax of 1913, which was adopted shortly after the ratification of the Sixteenth Amendment, encompassed only fourteen pages of statutes. ${ }^{1}$ It did not specifically address intellectual property and scant administrative

1. Revenue Act of 1913 , ch. 16, 38 Stat. 114, 116-80. The first income tax was not enacted until 1862. Revenue Act of 1862 , ch. 119, 12 Stat. 432 (repealed 1872); see also U.S. DEP'T OF THE TREASURY, Fact Sheet on the History of the U.S. Tax System, http://www.ustreas.gov/education/fact-sheets/taxes/ustax.shtml (last visited October 22, 2010). The income tax was reinstated in 1894. Revenue Act of 1894 , ch. 349,28 Stat. 570. But, it was shortly thereafter declared unconstitutional as a direct tax not apportioned among the states. Pollock v. Farmers' Loan \& Trust Co., 158 U.S. 601, 637 (1895). This led to the adoption of the Sixteenth Amendment in 1913, which allows Congress to levy a direct tax without apportionment. U.S. Const. amend. XVI. See generally Michael J. Graetz \& Deborah H. Schenk, Federal Income Taxation: Principles and Policies 6-7 (6th ed. 2009); I. Richard Gershon \& JeFFrey A. MaIne, A Student's Guide to the Internal Revenue CODE 1-2 (5th ed. 2007). 
guidance existed on the application of traditional tax principles to intellectual property transactions. This was of no particular consequence at a time when tangible, physical property was the driving engine of commerce.

As intellectual property's role in the world economy increased so, too, did the controversies between taxpayers and the government over the tax implications of intellectual property transactions (e.g., development, acquisitions, sales, and licenses). Equipped only with general tax rules, which had theretofore been applied only to tangible assets, courts were increasingly faced with important, new questions. For example, should research and development costs be currently deductible under general tax principles even though the research may not result in the development of a patent or other identifiable asset? Should a copyright assignment be treated as a "sale" under general tax principles, even though payment is in the form of royalties? Should litigation costs in patent infringement suits be treated the same for tax purposes as litigation costs in trademark infringement suits? There was considerable diversity of opinion among the courts dealing with these and other significant tax issues involving intellectual property. Sound federal tax legislation was necessary to improve the clarity and consistency of tax results.

Congress did not begin enacting specific intellectual property tax rules until the mid-twentieth century, even though intellectual property laws relating to protection and enforcement had been developing since the inception of the nation. As a result of tax legislation over the past six decades, the Internal Revenue Code (the Code) contains several specific rules governing major transactions involving various forms of intellectual property. Some of the present rules are exclusive, governing specific forms of intellectual property; others are equally applicable to all forms of intellectual property. While some of the rules were designed to support intellectual property goals (i.e., to incentivize desirable intellectual property activity and promote economic growth), the vast majority of the specific tax rules were enacted on an ad hoc basis with particular tax goals in mind. This Article traces the historic development of the specific tax rules governing intellectual property, identifies present areas of policy dissonance in the intersection of intellectual property and taxation, and calls for an appropriate legal framework for future intellectual property tax legislation.

Part II of the Article describes how early courts struggled to understand the unique attributes of intellectual property and their relevance under general tax principles in resolving intellectual property disputes. Because some of the earliest disputes involved the taxation of patent transactions, Part II provides several examples of early tax uncertainties in the life cycle of a patent.

Part III identifies underlying causes of early procedural dissonance between intellectual property and taxation that resulted when traditional principles of taxation applicable to tangible property were applied to intellectual property transactions. Specifically, Part III argues that this procedural dissonance resulted primarily from three sources: (1) difficulty identifying when intangible intellectual property rights constituted separable property for tax purposes when competing concepts of property could yield differing tax results; (2) 
difficulty reconciling the substantive similarities and differences among the forms of intellectual property in determining proper tax results and developing frameworks for future guidance; and (3) difficulty establishing, for tax purposes, the relevance of tangible media embodying intellectual property visà-vis the intangible legal attributes of intellectual property. Part III highlights the need for a rational set of special tax rules to resolve uncertainties and difficulties that arose upon the early intersection of intellectual property and taxation.

Part IV of the Article examines legislative responses to early dissonance between the intellectual property regime and historic tax principles. In analyzing intellectual property tax rules, it is helpful to understand as much as possible about why they exist and how they fit into or conflict with the intellectual property scheme. To that end, Part IV analyzes tax rules specific to intellectual property in terms of their legislative purpose and seeks to identify common goals behind special intellectual property tax rules. Part V observes that, although a few tax provisions were designed to achieve important intellectual property goals, the vast majority were designed with specific tax goals in mind: to remove tax inequities or to enhance administrative efficiency.

The addition of specific tax rules governing intellectual property achieved necessary procedural harmonization between the intellectual property and taxation schemes. Part V, however, shows that the resulting tax regime may not be adequately relevant in reflecting the evolution of technology and the reality of today's economy, such as the current integration and bundling of different types of intellectual property in practice. These, and perhaps other, areas of existing dissonance in the intersection of intellectual property and taxation need to be addressed if the tax system is to foster the intellectual property system's innovation objectives. ${ }^{2}$

\section{HISTORICAL PERSPECTIVE: APPL YING NORMATIVE TAX PRINCIPLES TO INTELLECTUAL PROPERTY}

The term "intellectual property" was first mentioned in Davoll v. Brown, a Massachusetts case decided in $1845^{3}$ The term "intellectual property"

2. This Article traces the development of specific tax rules governing intellectual property and notes the need for harmonization between the intellectual property and taxation schemes. For a critique of the broader intellectual property tax regime (which includes a combination of special and general tax rules) using normative criteria in evaluating taxes (equity and efficiency) and for a proposed legal framework for future tax legislation, see Xuan-Thao Nguyen \& Jeffrey A. Maine, Equity and Efficiency in Intellectual Property Taxation, 76 BROOK. L. REV. 1 (2010).

3. Davoll v. Brown, 7 F. Cas. 197, 199 (C.C.D. Mass. 1845) ("A liberal construction is to be given to a patent, and inventors sustained, if practicable, without a departure from sound principles. Only thus can ingenuity and perseverance be encouraged to exert themselves in this way usefully to the community; and only in this way can we protect intellectual property, the labors of the mind, productions and interests as much a man's own, and as much the fruit of his honest industry, as the wheat he cultivates, or the flocks he rears."); see also Peter S. Menell, Intellectual Property and the Property Rights Movement, Regulation, Fall 2007, at 37, available at http//www.cato.org/pubs/regulation/regv30n3/v30n3-6.pdf (citing Davoll v. Brown as the first reported legal decision using the term "intellectual property"). 
generally refers to patents, copyrights, trademarks, and trade secrets. ${ }^{4}$ Though the term "intellectual property" came into existence in the nineteenth century, different types of intellectual property have been in existence for a much longer time. ${ }^{5}$ Some have been around for several hundred years ${ }^{6}$ and others for several thousand years.

Early federal income tax laws did not deal specifically with intellectual property assets even though protections for these rights had long existed. ${ }^{8}$ At the beginning of our nation, Congress had the enumerated power to lay and collect tax. ${ }^{9}$ Early on Congress levied numerous tariffs on items such as distilled spirits, tobacco and snuff, auction sales, and various legal documents. ${ }^{10}$ The first income tax, however, was not enacted until 1862 , to

4. See BLACK's LAW Dictionary 881 (9th ed. 2009).

5. See generally Leah Chan Grinvald, Making Much Ado About Theory: The Chinese Trademark Law, 15 Mich. Telecomm. \& TeCH. L. REV. 53, 70-71 (2008) (explaining the historical foundation of Chinese trademarks in antiquity); Xuan-Thao N. Nguyen, Holding Intellectual Property, 39 GA. L. REV. 1155, 1159 n.10 (2005) (noting the development of trademarks as source identifiers).

6. See generally Bruce W. Bugbee, Genesis of American Patent and Copyright LAw 43-44 (1967) (stating that under the Venetian Patent Statute, the Venetian government granted a privilegi to Marc' Antonio Sabellico on September 1, 1486, for his work of authorship, Decades renum Cenetarum); Francis J. Swayze, The Growing Law, 25 YALE L.J. 1, 10 (1915) (observing the growing body of law relating to copyrights in the eighteenth century).

7. See Milton E. Babirak, Jr., The Maryland Uniform Trade Secrets Act: A Critical Summary of the Act and Case Law, 31 U. BALT. L. REV. 181, 183 (2002) (noting the history of trademark law in ancient Rome and Greece); Ke Shao, Look at My Sign!-Trademarks in China from Antiquity to the Early Modern Times, 87 J. PAT. \& Trademark OfF. SOC'Y 654, 654 (2005) (tracing the history of trademark usage in China for several thousand years); Alan Watson, Trade Secrets and Roman Law: The Myth Exploded, 11 Tul. EuR. \& Crv. L.F. 19, 19 (1996) (disputing the accuracy of assertions relating to Roman trade secrets law).

8. See supra note 7 and accompanying text, infra notes $9-13$ and accompanying text.

9. See U.S. ConST. art. I, $\S 8$, cl. 1 ("The Congress shall have Power To lay and collect Taxes, Duties, Imposts and Excises, ... but all Duties, Imposts and Excises shall be uniform throughout the United States."); Ellen P. Aprill \& Richard Schmalbeck, Post-Disaster Tax Legislation: A Series of Unfortunate Events, 56 DuKE L.J. 51, 79-81 (2006) (analyzing Congress's taxing power under Article I, Section 8 of the Constitution and the requirement for uniform federal tax law throughout the United States). See generally Yoseph Edrey, Constitutional Review and Tax Law: An Analytical Framework, 56 AM. U. L. REV. 1187, 1191 (2007) (explaining that the power of Congress in Article I, Section 8 of the Constitution to levy taxes is broad); Gregory E. Maggs, A Concise Guide to the Federalist Papers as a Source of the Original Meaning of the United States Constitution, 87 B.U. L. REv. 801, 835-37 (2007) (discussing Congress's power to tax and the Framers' original intent).

Interestingly, the same Section of Article I also vests in Congress the power to grant copyright and patent rights to authors and inventors. See, e.g., Irah Donner, The Copyright Clause of the U.S. Constitution: Why Did the Framers Include it with Unanimous Approval?, 36 Am. J. Legal Hist. 361, 361 (1992); Paul J. Heald \& Suzanna Sherry, Implied Limits on the Legislative Power: The Intellectual Property Clause as an Absolute Constraint on Congress, 2000 U. Ill. L. REV. 1119, 1143-60; Rebecca C.E. McFadyen, The "First-to-File" Patent System: Why Adoption is Not an Option!, 14 Rich. J.L. \& TECH. 3, 17-23 (2007) (tracing the roots of the Patent and Copyright Clause in Article I, Section 8 of the Constitution); Edward C. Walterscheid, To Promote the Progress of Science and Useful Arts: The Background and Origin of the Intellectual Property Clause of the United States Constitution, 2 J. INTELL. Prop. L. 1, 10 (1994).

10. For a brief history of taxation in the United States, see GRAETZ \& SCHENK, supra note 1, at 4-12. The Department of Treasury's website also provides a brief history of the U.S. tax system:

To pay the debts of the Revolutionary War, Congress levied excise taxes on 
help finance the Civil War, and it was repealed after the war in 1872 due to the decline in the need for federal revenue. ${ }^{11}$ The income tax was reinstated in 1894 but was declared unconstitutional shortly thereafter as a direct tax not apportioned among the states. ${ }^{12}$ This led to the adoption of the Sixteenth Amendment in 1913, which allows Congress to levy a direct tax without apportionment. ${ }^{13}$ The Income Tax of 1913 was adopted shortly after the ratification of the Sixteenth Amendment. ${ }^{14}$

These early income tax laws were void of tax rules specific to intellectual property. ${ }^{15}$ This was of no particular consequence at a time when tangible, physical property was the driving engine of modern commerce. As intellectual property became the dominant source of wealth in the world, however, the tax implications of intellectual property transactions became more important. Courts were called upon to resolve numerous controversies between taxpayers and the government over the tax consequences of intellectual property development, acquisitions, and dispositions. Because the existing tax regime did not specifically address these matters, courts were forced to rely upon general tax principles in resolving tax disputes. Outcomes were diverse as courts struggled to understand the unique, intangible characteristics of intellectual property and to determine their relevance under general tax rules applicable to tangible property.

Some of the earliest tax debates involved patent transactions. To frame some of the issues with which courts struggled, the following example is provided. It highlights tax uncertainties in the life cycle of a patentdevelopment, acquisition, and disposition. As is demonstrated, the intangible nature of patent rights challenged many early notions of tax law.

distilled spirits, tobacco and snuff, refined sugar, carriages, property sold at auctions, and various legal documents. ...

During the confrontation with France in the late 1790's, the Federal Government imposed the first direct taxes on the owners of houses, land, slaves, and estates. ... When the Civil War erupted, the Congress passed the Revenue Act of 1861, which restored earlier excises taxes and imposed a tax on personal incomes. ...

On July 1, 1862 the Congress passed new excise taxes on such items as playing cards, gunpowder, feathers, telegrams, iron, leather, pianos, yachts, billiard tables, drugs, patent medicines, and whiskey. Many legal documents were also taxed and license fees were collected for almost all professions and trades. . . . The need for Federal revenue declined sharply after the war and most taxes were repealed. By 1868, the main source of Government revenue derived from liquor and tobacco taxes. The income tax was abolished in 1872 . From 1868 to 1913 , almost 90 percent of all revenue was collected from the remaining excises.

U.S. DEP'T OF THE TREASURY, supra note 1.

11. Id.

12. Pollock v. Farmers' Loan \& Trust Co., 158 U.S. 601, 637 (1895).

13. U.S. Const. amend. XVI ("The Congress shall have Power to lay and collect taxes on incomes, from whatever source derived, without apportionment among the several States, and without regard to any census or enumeration.").

14. Revenue Act of 1913 , ch. 16,38 Stat. $114,166-80$.

15. There has been a tremendous amount of tax legislation since 1913. It was not until 1950 , however, that Congress enacted a tax provision specific to intellectual property. See infra Part V. 


\section{A. APPLYING GENERAL ASSET CAPITALIZATION TO RESEARCH COSTS}

Since inception of the modern federal income tax, the Code has permitted a current deduction for ordinary and necessary business expenses. ${ }^{16}$ The Code has precluded, however, a current deduction for so-called "capital expenditures," historically viewed as any expenditure that produces an asset lasting beyond the current tax period. ${ }^{17}$ Applying the asset capitalization rule to tangible property presents few problems. If a business spends money to construct a widget-making machine, a classic capital asset (i.e., a separate and distinct asset lasting beyond the construction year), the construction costs are not currently deductible. ${ }^{18}$ In contrast, applying the asset capitalization rule to research and development costs can be challenging for a number of reasons. It is often difficult to determine when research activities result in an identifiable asset, the costs of which must be capitalized. Further, because research may span several years with varying degrees of success, it is often difficult to apportion costs if a particular project partly succeeds and partly fails or when different and simultaneous research activities contribute in varying degrees to the development of an asset or assets. ${ }^{19}$

Perhaps it was for these reasons that the Treasury adopted a liberal approach in its initial treatment of research costs. In 1919, it promulgated a regulation that gave taxpayers the option of either deducting or capitalizing expenses "for designs, drawings, patterns, models, or work of an experimental nature [if] calculated to result in improvement[s] of [taxpayers'] facilities or [taxpayers'] product $[\mathrm{s}], " 20$ Shortly thereafter, however, the Treasury deleted the regulation ${ }^{21}$ because it found that certain taxpayers were enjoying double tax

16. Revenue Act of 1913 , ch. $16, \S$ II(B), 38 Stat. 114,167 (" $[\mathrm{I}] \mathrm{n}$ computing net income for the purpose of the normal tax there shall be allowed as deductions: First, the necessary expenses actually paid in carrying on any business ...."). For the current business expense allowance provision, see I.R.C. $\$ 162(2010)$.

17. Revenue Act of 1913 , ch. $16, \S \mathrm{II}(\mathrm{B}), 38$ Stat. 114,167 (providing "[t]hat no deduction shall be allowed for any amount paid out for new buildings, permanent improvements, or betterments, made to increase the value of any property"). For the current disallowance provisions, see I.R.C. $\S \S 263,263 \mathrm{~A}$ (2010). The reason capital expenditures are not currently deductible is that the property created or acquired is not consumed or used up within the year but rather continues to contribute to income over a period of years. If the costs incurred in the creation or acquisition of such property were deductible in full in the current year, there would be a mismatching of income and expenses that produced that income; income would be understated in the year of creation or acquisition and overstated in later years. By prohibiting the immediate deduction of capital expenditures, this problem is avoided.

18. See I.R.C. $\S \S 263(a), 263$ A(a) (2010); Prop. Treas. Reg. $\S 1.263(a)-2,73$ Fed. Reg. $12838,12852-56$ (Mar. 10, 2008) (providing rules for applying section 263 to amounts paid to produce tangible property).

19. See David S. Hudson, The Tax Concept of Research or Experimentation, 45 TAX LAW. $85,88-89$ (1991) (explaining why the asset-capitalization rule is difficult to apply to research and development costs); see also George Mundstock, Taxation of Business Intangible Capital, $135 \mathrm{U}$. PA. L. REV. $1179,1258-59$ (1987).

20. Revenue Act of 1918, Pub. L. No. 254, 40 Stat. 1057 (1919) (Regulation 45 states: "A taxpayer who has incurred expenses in his business for designs, drawings, patterns, models, or work of an experimental nature calculated to result in improvement of his facilities or his product, may at his option deduct such expenses from gross income for the taxable year in which they are incurred or treat such articles as a capital asset to the extent of the amount so expended.").

21. Treas. Reg. 69 , art. 168 (1926). 
benefits from their research-i.e., deducting research expenses when paid, but also capitalizing them in the basis of developed patents thereby reducing gain on later sales. ${ }^{22}$ Even though the Treasury eliminated the deduction option, the Internal Revenue Service (the Service) continued to allow certain taxpayers to deduct research expenditures - namely those taxpayers who engaged in regular and continual research activities and who had established practices of accounting for research costs. ${ }^{23}$ Courts did not necessarily find the Service's administrative policy binding. ${ }^{24}$ Indeed, if the Service challenged the deduction of research costs incurred in the development of new processes, formulae, or patents, courts generally adhered to the asset-capitalization principle. ${ }^{25}$

But without a framework for resolving tax disputes, courts struggled to apply the asset-capitalization rule to research costs. Should capitalization depend on the taxpayer's subjective intent or purpose of research activities, or should capitalization depend on the success of research activities? In other words, should capitalization be required if the taxpayer intends to improve an existing product or develop a new process or patent, or should capitalization be required only if the taxpayer develops a capital asset having a useful life beyond the year? Moreover, should a distinction be drawn between expenditures incurred for general scientific research and expenditures to develop patents on a particular process or formula? And when should capitalization apply to payments for technical assistance and know-how of services? There was lack of uniformity in addressing these and other important questions. ${ }^{26}$

22. The Board of Tax Appeals (predecessor to the Tax Court), in at least two cases, sanctioned the double tax benefit. See Gilliam Mfg. Co. v. Comm'r, 1 B.T.A. 967, 970 (1925); Goodell-Pratt Co. v. Comm'r, 3 B.T.A. 30, 33-34 (1925). In these cases, the government argued capitalization was not appropriate since the taxpayer had elected earlier to deduct research costs. The court found, however, that capitalization was proper since research costs resulted in creation of a patent. Gilliam Mfg. Co., 1 B.T.A. at 970; Goodell-Pratt Co., 3 B.T.A. at 32. For the early treatment of research expenses, see generally Donald C. Alexander, Research and Experimental Expenditures Under the 1954 Code, 10 TAx L. REV. 549 (1955); James L. Musselman, Research and Experimental Expenditures-The Evolution of Deductibility Under the Trade or Business Requirement of Section 174 of the Internal Revemie Code, 42 RUTGERS L. REV. 757 (1990).

23. See Red Star Yeast \& Prods. Co. v. Comm'r, 25 T.C. 321, 341-42 (1955) (quoting statement by former Internal Revenue Service Commissioner Dunlap).

24. Id. at 343 .

25. See, e.g., Claude Neon Lights, Inc. v. Comm'r, 35 B.T.A. 424 (1937); Hazeltine Corp. v. Comm'r, 32 B.T.A. 110 (1935), aff'd, 89 F.2d 513 (3d Cir. 1937); Clem v. Comm'r, 10 T.C.M. (CCH) 1248 (1951).

26. In Strong, for example, the taxpayer spent sums to perfect a machine, but did not improve the machine or develop anything that was of subsequent use to him. Strong v. Comm'r, 14 B.T.A. 902, 903 (1928). The Board of Tax Appeals held that the research costs were deductible because the amounts did not result in the acquisition, development, or improvement of a capital asset having a useful life beyond the year; the taxpayer was engaged in purely experimental work in the development of this machine. Id. at 903-04. On similar facts, a different court required capitalization of research costs. Hart-Bartlett-Sturtevant Grain Co. v. Comm'r, 182 F.2d 153, 156 (8th Cir. 1950). In Hart-Bartlett-Sturtevant Grain Co., the taxpayer spent money to develop a new product from agricultural material using biological processes; however nothing of commercial value or of patentable nature was developed, so the biological research was dropped. Id. at 154-55. The court held that the research expenditures were not currently deductible since they were calculated to result in improvement of its facilities or its 
Requiring capitalization of research expenditures seemed somewhat harsh, especially if research efforts ultimately proved unsuccessful. In such cases, tax law did permit an abandonment loss deduction for the year in which abandonment occurred. ${ }^{27}$ But a loss deduction upon subsequent failure of research efforts was hardly viewed as an adequate economic incentive for taxpayers to engage in desirable research activities. ${ }^{28}$ This highlights a fundamental problem with the general asset-capitalization rule: not only was it highly difficult to apply to research and development, but more significantly, it also served to actually discourage important research and experimentation.

\section{B. APPLYING HISTORIC DEPRECIATION RULES TO PATENT ACQUISITION COSTS}

In an economic sense, depreciation is the decline in value of an asset due to wear and tear and obsolescence. ${ }^{30}$ From the tax perspective, depreciation is a deduction from income, permitting the taxpayer to recover the capitalized cost of that asset. ${ }^{31}$ Depreciation methods are sometimes called cost recovery systems. ${ }^{32}$ So, for example, if an asset used in business for five years cost a taxpayer $\$ 20,000$, the taxpayer might take a $\$ 4,000$ deduction each year on her taxes for five years to reflect the decline in value of that asset and to reflect its contribution to the production of taxable income. The entire cost of the asset is not deducted all at once because the asset helped produce income over five years. ${ }^{33}$ To match the taxpayer's expenses against the revenues they helped produce, the taxpayer must spread out the deduction over the useful life of the asset. $^{34}$ This is, of course, a basic application of the principle discussed above - that the costs of assets must be capitalized.

An early Treasury regulation adopted a seemingly simple rule for the

products: "[W]e cannot conclude that it was not within the contemplation [of the taxpayer] that research . . . might develop something of a commercial and permanent value to petitioner." Id. at 156.

27. Id. at 157 ("Where there has been a complete abandonment of experiments and failure becomes an actual fact, a loss may be taken by way of deduction . ..."); see Dresser Mfg. Co. v. Comm'r, 40 B.T.A. 341, 345-46 (1939); Acme Prod Co. v. Comm'r, 24 B.T.A. 194, 196 (1931); see also Clem, 10 T.C.M. (CCH) at 1248 (disallowing an abandonment deduction as taxpayer was still engaged in developing and perfecting his machine).

28. Taxpayers will nearly always be economically advantaged by the acceleration of tax deductions. Current deductions reduce the taxpayer's current tax liability thereby leaving the taxpayer with the use of his or her money for longer. Because money makes money, the use of money has value. This is commonly referred to as "the time value of money." See generally Pamela Peterson Drake \& Frank J. Fabozzi, Foundations and applications of the TIME VALUe OF MONEY (2009).

29. Internal Revemue Code of 1954: Hearing on H.R. 8300 Before the S. Comm. on Finance, 83d Cong., 2d Sess. 105 (1954).

30. Black's LaW Dictionary 506 (9th ed. 2009).

31. James J. FreEland et AL., Fund amentals of Federal Income Taxation 407 (5th ed. 2009).

32. Id. at 408-09.

33. See id. at $407-08$.

34. At the end of the asset's useful life, the acquisition costs will have been fully recovered, and the asset's basis will be zero, reflecting that all capitalized costs have been recovered fully. See I.R.C. \& 1016(a)(2) (2010) (providing that the asset's basis is reduced each year as depreciation deductions are taken with respect to the asset). 
depreciation of intangible assets. If an acquired intangible asset could be shown to have a limited useful life, then the capitalized acquisition costs were recoverable (deductible) over that asset's lifetime. ${ }^{35}$ As a corollary, the capitalized cost of an intangible asset that had no definite useful life was not recoverable through depreciation but could only be recovered upon abandonment or disposition of the asset. ${ }^{36}$ Under this legal framework, patents and copyrights were eligible for depreciation due to the fact that they have limited useful lives (statutory legal lives of 20 years in the case of patents, and 70,95 , or 120 years in the case of certain copyrights). ${ }^{37}$ In contrast, other traditional intellectual property rights (trade secrets, trademarks, trade names) were not eligible for depreciation because they do not have limited lives. ${ }^{38}$ The same was true for goodwill; the costs of acquiring goodwill were not eligible for amortization allowances, as goodwill does not have an ascertainable limited life. ${ }^{39}$ These early depreciation rules for recovering the capitalized costs of intangibles created several problems.

One problem with the historic depreciation rule for intangibles was that it caused much litigation concerning the identification and valuation of intangible assets. ${ }^{40}$ No deduction for depreciation was allowable with respect to goodwill, so taxpayers tried to distinguish intangible assets from goodwill; the Service often challenged those determinations. ${ }^{4 \mathrm{~T}}$ The touching point was that

35. Treas. Reg. $§ 1.167$ (a)-3 (1960) ("If an intangible asset is known from experience or other factors to be of use in the business or in the production of income for only a limited period, the length of which can be estimated with reasonable accuracy, such an intangible asset may be the subject of a depreciation allowance.").

36. Id. ("An intangible asset, the useful life of which is not limited, is not subject to the allowance for depreciation.").

37. A patent confers the right to exclude others from making, using, selling, offering for sale, or importing the claimed invention for a certain term of years (currently twenty years from the date of application). 35 U.S.C. \& 154(a)(2), (d) (2001). Ownership of a valid copyright confers five exclusive rights for a limited time. Id. The Copyright Act, over the years, has lengthened the term of copyright protection. Currently, a work of authorship enjoys a term of the life of the author and seventy years thereafter. 17 U.S.C. $\S 302$ (a) (2005). For works created under the doctrine of "works made for hire," the term is ninety-five years after first publication or 120 years after creation. Id. $\S 302$ (c).

38. There is no specific term of protection for trade secrets; the protection is available as long as confidential proprietary information is kept in secrecy, which could be indefinite. See UNIF. TRADE SECRETS ACT $\$ 1$ (amended 1985), 14 U.L.A. 537-38 (1990). Likewise, there is no specific term of protection for trademarks and trade names; the protection is available as long as the trademark or trade name is used in commerce and has not been abandoned. See 15 U.S.C. $\S$ 1127 (2009) (providing presumption of abandonment if nonuse of a trademark extends for three years).

39. Xuan-Thao N. Nguyen \& Jeffrey A. Maine, Taxing the New Intellectual Property Right, 56 HASTINGS L.J. 1, $14 \mathrm{n} .75$ (2004) ("The prohibition against amortizing the cost of goodwill first appeared in Treas. Reg. $\$ 1.167$ (a)-3, which stated that ' $[\mathrm{n}] \mathrm{o}$ deduction for depreciation is allowable with respect to goodwill.' This prohibition first appeared in the regulations in 1927. See Kevin R. Conzelmann, 533-2d T.M., Amortization of Intangibles, A-5 \& n.32 (2001) (citing T.D. 4055 , VI-2 C.B. 63; Treas. Reg. 69, Art. 163 (Revenue Act of 1926))

40. See Catherine L. Hammond, The Amortization of Intangible Assets: $\$ 197$ of the Internal Revemue Code Settles the Confusion, 27 ConN. L. REv. 915, 918 (1955) ("Because the determination of whether an intangible can be amortized was a question of fact, the outcome of such litigation varied widely according to the circumstances of each particular case.").

41. Id. ("Additional confusion and litigation arose because the term 'goodwill' is not defined in the Code or in the regulations."). 
goodwill was viewed by the government as an umbrella covering all intangible assets of a business. This historical concept of goodwill led to considerable controversy between taxpayers and the Service. While taxpayers attempted to argue that a wide variety of intangible assets were independent assets severable from goodwill (and eligible for depreciation provided they had a limited useful life), the Service strongly held to the position that these intangible assets were indistinguishable or inseparable from goodwill (and not eligible for depreciation). ${ }^{42}$ Clear guidance was needed for taxpayers who, for example, purchased patents along with certain associated trademarks and other intangibles.

Even if patents and other intangible assets were capable of being separately identified and valued, controversies existed over the appropriate cost recovery methods and recovery periods for such assets. A common method for depreciating patent costs was the so-called "straight-line method," under which capitalized acquisition costs are deducted ratably over the asset's estimated useful life. ${ }^{43}$ Application of this seemingly simple method raised a number of questions. For example, was the useful life of a patent the statutory legal life of the patent, or instead, the period over which the patent was reasonably expected to be useful to the taxpayer in his or her business or in the production of income? If the latter approach was appropriate, should the taxpayer establish useful life based upon some general industry standard, or should the taxpayer establish useful life of a patent based upon his or her own experiences with similar property? If useful life was based on taxpayer experiences, what was the appropriate standard in forecasting the asset's useful life? In 1969, the Service authorized a five-year amortization period for software acquisition costs rendering these questions moot for software. ${ }^{44}$

The usefulness of some patents is not adequately measurable by the passage of time alone but is more accurately measurable by the income the patent produces. As a result of distortions caused by the straight-line method, the Service eventually permitted patents to be depreciated under the so-called "income forecast method," under which costs are recovered as income is earned from exploitation of the patent. ${ }^{45}$ The depreciation allowance in any given year is computed by multiplying the original capitalized acquisition cost of the patent by a fraction, the numerator of which is income from the patent for the taxable year, and the denominator of which is the forecasted or estimated total income to be earned in connection with the patent during its

42. The controversy over whether to characterize intangible assets as goodwill was eventually settled with the Supreme Court's decision in Newark Morning Ledger Co. v. United States. 507 U.S. 546, 570 (1993). The Supreme Court held that amortization of an intangible asset depends on whether the asset is capable of being valued and whether the asset has a limited useful life. Id. The Court rejected the Service's argument that a taxpayer must also prove that the intangible is separate and distinct from goodwill. Id.

43. Treas. Reg. $\$ 1.167$ (b)-1 (1960).

44. Rev. Proc. 69-21, 1969-2 C.B. 303, superseded by Rev. Proc. 2000-50, 2000-1 C.B. 601.

45. Rev. Rul. $60-358,1960-2$ C.B. 68 , amplified by Rev. Rul. $64-273,1964-2$ C.B. 62 , amplified by Rev. Rul. 79-285, 1979-2 C.B. 91. 
useful life. ${ }^{46}$ While the income forecast method is perhaps more accurate in reflecting income than the straight-line method, its application is complex. It is often difficult to determine yearly and forecasted income for purposes of the above formula; revised computations are required if estimates are substantially overstated or underestimated as a result of circumstances that arise in later years, ${ }^{47}$ and a complex set of "look back" rules may require a taxpayer to pay interest to the government if deductions were accelerated due to underestimation of expected income. ${ }^{48}$

Another problem with the historical depreciation scheme stemmed from the fact that the rules for depreciating intangible intellectual property assets differed dramatically from the corresponding set of rules for depreciating tangible assets. Over time, Congress enacted a detailed set of arbitrary depreciation rules for all tangible assets. These Code provisions provided arbitrary conventions and methods for depreciating costs of tangible assets and, more importantly, provided artificially low recovery periods (e.g., three, five, and seven years) for many tangible assets that arguably have longer useful lives. ${ }^{49}$ This disparate treatment between intellectual property assets and tangible assets created distortions that were unfair to taxpayers. ${ }^{50}$ For example, taxpayers who acquired businesses with mostly tangible assets fared better than taxpayers who acquired businesses with mostly intellectual property assets, a problem that worsened as more and more valuable business assets took the form of intellectual property assets. ${ }^{51}$ Seeking to mitigate these distortions, many saw the need to reconcile the treatment of acquired intangible assets with the treatment of acquired tangible assets. ${ }^{52}$

\section{APPLYING GENERAL SALE PRINCIPLES TO PATENT DisPositions}

A transfer of property for consideration is treated for tax purposes as either a sale or a license-with significant tax differences depending on how the transfer is characterized. If a property transfer is considered a sale for tax purposes, then the transferor is permitted to recover tax-free any remaining

46. The following simple example illustrates the computation: In Year 1, Taxpayer purchases a patent for $\$ 100$ and estimates that forecasted total income from the patent will be $\$ 200$. In Year 1 , the patent generates income of $\$ 80$. The depreciation allowance for Year 1 is $\$ 40$, computed by multiplying the capitalized acquisition cost of $\$ 100$ by the fraction obtained by dividing current year income of $\$ 80$ by forecasted total income of $\$ 200$. Under this approach, $40 \%$ of forecasted income was earned in Year 1, so $40 \%$ of the total purchase cost was deducted in Year 1. See Treas. Reg. §1.167(n)-4(e), Ex. 1.

47. Treas. Reg. §1.167(n)-4(b).

48. Id. $\S 1.167(\mathrm{n})-6$.

49. See I.R.C. $\S \S 167,168$ (2010) (providing a set of arbitrary rules for determining the appropriate depreciation allowance for all forms of tangible property, both personal and real).

50. See Allen Walburn, Depreciation of Intangibles: An Area of the Tax Law in Need of Change, 30 SAN DIEGO L. REV. 453, 454-56 (1993) (explaining that the inequity between similarly situated taxpayers resulted in noncompliance and much litigation, which unnecessarily burdened the administration of tax law).

51. See Conzelmann, supra note 39, at A-3 \& n.7 (citing Newark Morning Ledger Co. v. United States and noting that taxpayers with resources "had a much better success rate in litigation than poorer taxpayers").

52. Id. 
basis in the property transferred ${ }^{53}$ and the resulting gain may be taxed at preferential capital gain rates rather than the much higher ordinary income rates. ${ }^{54}$ If, however, the transfer is characterized as a license for tax purposes, the transferor is not permitted to recover any basis in the property, and the full amounts received must be reported and taxed as ordinary income rather than capital gain. Characterizing a transfer of tangible property as either a sale or license for tax purposes is relatively straightforward in most cases. If a property owner has fee simple title to a piece of land (i.e., owns the whole "bundle of sticks" or "attributes of ownership") and transfers title in fee simple to a buyer for consideration, a "sale" has occurred. Characterizing the transfer of intangible intellectual property rights under general tax principles is not as easy.

Determining whether a patent transfer was a sale or license under general tax principles was the subject of many early court decisions. In contrast to most land transactions, wherein sellers transfer all attributes of ownership for a lump sum, patent transfers typically include numerous limitations and restrictions and often involve contingent payments resembling royalties. And so numerous courts were called upon to tackle hard questions: What are the substantial attributes of patent ownership? Must the entire bundle of rights (sticks) be given away for sale treatment, or may certain rights be retained? Should the existence of contingent payments preclude sale treatment even if all ownership rights were transferred?

In establishing the basic criteria of a sale under general tax rules, courts held that a patent owner must transfer the exclusive right to make, use, and sell the patented article; anything short of that was not a sale but a license. ${ }^{55}$ An

53. I.R.C. $\S 1001$ (a) (2010) (providing the amount of gain on the sale of property is equal to the excess of the amount realized in the transaction over the amount of the taxpayer's adjusted basis in the property sold).

54. Individual taxpayers generally prefer gains to be classified as capital gains rather than ordinary income because certain capital gains are afforded preferential tax treatment. Presently, the maximum rate at which most long-term capital gains are taxed is $15 \%$, whereas the highest rate at which other types of income (ordinary income and short-term capital gains) are taxed is $35 \%$ - a significant rate differential for high earners. See I.R.C. \& 1(a)-(d), (i)(1)-(2). Under general tax principles, preferential capital gain treatment requires a "sale or exchange" of a "capital asset." I.R.C. $\S \S 1221,1222$ (2010). See John A. Miller \& JefFrey A. MaINE, The FUNDAMENTALS OF FEDERAL TAXATION 219 (2d ed. 2010) (giving several policy reasons for the tax rate preference accorded to capital gains).

55. A large number of tax cases followed Waterman, one of the leading authorities dealing with the transfer of patents. Waterman v. Mackenzie, 138 U.S. 252 (1891). In that case, the Supreme Court said:

Whether a transfer of a particular right or interest under a patent is an assignment or a license does not depend upon the name by which it calls itself, but upon the legal effect of its provisions. For instance, a grant of an exclusive right to make, use, and vend two patented machines within a certain district is an assignment, and gives the grantee the right to sue in his own name for an infringement within the district, because the right, although limited to making, using, and vending two machines, excludes all other persons, even the patentee, from making, using, or vending like machines within the district. On the other hand, the grant of an exclusive right under the patent within a certain district, which does not include the right to make, and the right to use, and the right to sell, is not a grant of a title in the whole patent-right within the district, and is therefore only a license. Such, for 
"exclusive license" to manufacture, use, and sell for the life of a patent would be considered a sale because, in substantive effect, all right, title, and interest in the property was transferred irrespective of the location of legal title or other formalities of language contained in the license agreement. ${ }^{56}$ In contrast, a "nonexclusive license" - a transfer that granted the transferee only segregated or limited rights - would be considered a license rather than a sale. ${ }^{57}$ For example, transfers with duration limitations, ${ }^{58}$ transfers that divided the manufacturing of patents between the transferor and transferee, ${ }^{59}$ and transfers that granted the right to make and sell but not the right to "use" 60 were generally treated as licenses rather than sales for tax purposes.

Under this broad framework, much litigation centered on determining what restrictions or limitations in particular patent agreements precluded a finding of a sale for tax purposes. Many patent assignments contain geographical limitations or field-of-use restrictions. Should the grant of an exclusive right to make, use, and sell a patent to only a certain geographical area be considered a sale for tax purposes, even though the transferor retained those rights with respect to all other geographical areas? ${ }^{61}$ Similarly, should the grant of the exclusive right to make, use, and sell a patent to only a particular industry be considered a sale for tax purposes even though the transferor retained those

instance, is a grant of 'the full and exclusive right to make and vend' within a certain district, reserving to the grantor the right to make within the district, to be sold outside of it. So is a grant of 'the exclusive right to make and use,' but not to sell, patented machines within a certain district. So is an instrument granting 'the sole right and privilege of manufacturing and selling' patented articles, and not expressly authorizing their use, because, though this might carry by implication the right to use articles made under the patent by the licensee, it certainly would not authorize him to use such articles made by others.

Id. at 255-56 (holding that an agreement by which a patent owner granted "the sole and exclusive right and license to manufacture and sell" the patented article throughout the United States was not an assignment, but a license) (internal citations omitted). Waterman involved the question of who were the indispensable parties in an infringement suit. As a result, not all courts followed the Court's view as to what constitutes a patent assignment for tax purposes. See, e.g., Bloch v. United States, 200 F.2d 63 (2d Cir. 1952) ("Different considerations were obviously involved, and the court's statement as to what constitutes an assignment of title to a patent is not necessarily controlling in the field of taxation.")

56. See, e.g., Rollman v. Comm'r, 244 F.2d 634 (4th Cir. 1957); Watson v. United States, 222 F.2d 689 (10th Cir. 1955).

57. Id.

58. See, e.g., Oak Mfg. Co. v. United States, 301 F.2d 259, 263 (7th Cir. 1962); Bell Intercontinental Corp. v. United States, 381 F.2d 1004, 1023 (Ct. Cl. 1967); PPG Indus., Inc. v. Comm'r, 55 T.C. 928,1018 (1970); Gregg v. Comm'r, 18 T.C. 291, 302 (1952), aff' d per curium, 203 F.2d 954, 955 (3d Cir. 1953).

59. See, e.g., Am. Chem. Paint v. Smith, 131 F. Supp. 734,739 (D.C. Pa. 1955).

60. See, e.g., Broderick v. Neale, 201 F.2d 621, 624 (10th Cir. 1953); Nat'1 Bread Wrapping Mach. Co. v. Comm'r, 30 T.C. 550,559 (1958); Cleveland Graphite Bronze Co. v. Comm'r, 10 T.C. 974, 991 (1948), aff'd per curium, 177 F.2d 200, 200 (6th Cir. 1949). But see Rollman, 244 F.2d at 641; C.A. Norgren Co. v. United States, 268 F. Supp. 816, 825 (D.C. Colo. 1967); Flanders v. United States, 172 F. Supp. 935, 950 (D.C. Cal. 1959).

61. For early cases holding that transfers were sales for tax purposes despite geographical limitations, see Watson, 222 F.2d at 689; Crook v. United States, 135 F. Supp. 242, 253 (W.D. Pa. 1955); Marco v. Comm'r, 25 T.C. 544,549 (1955), acq., 1958-2 C.B. 3. 
rights with respect to all other industries? ${ }^{62}$ Many patent agreements also contain certain restrictions that serve to protect the transferor, raising additional questions: Should a patent transfer be deemed a sale for tax purposes even though the transferor reserves the right to terminate in the event of transferee's insolvency, bankruptcy, or failure to make payments? ${ }^{63}$ Should a patent transfer be deemed a sale despite a restriction that the transferee cannot grant a sublicense without the written consent of the transferor, if the purchase price is paid in installments and the restriction served to protect the parties? ${ }^{64}$ Similarly, should the transferor's retention of the right to sue for infringement necessarily preclude a finding of a sale if the restriction is viewed as a security device? ${ }^{65}$

In addition to struggling with these important questions, the government and courts also struggled with the impact, if any, that contingent payments should have on the "license versus sale" determination. In contrast to real property transactions, which often involve lump sum or installment payments, patent agreements typically involve payments measured by the production, sale, or use by the transferee, or payments payable over a period generally coterminous with the transferee's use of the patent. And so the question arose: should a patent assignment be denied sale treatment solely because the purchase price took the form of contingent payments? Early cases were split on the issue. Some courts held that the receipt of contingent payments did not prevent a transfer from being considered a sale, ${ }^{66}$ while others held that the receipt of contingent payments did preclude sale treatment. ${ }^{67}$ The Service itself struggled with the issue. In a 1950 administrative pronouncement, the Service ruled that an assignment of a patent (or the exclusive license to make, use, and sell a patented article) would nevertheless be treated as a license for tax purposes (and, hence, payments received by inventors would be taxed as

62. For early cases holding that transfers were sales despite field-of-use restrictions, see Merck \& Co. v. Smith, 261 F.2d 162, 165-66 (3d Cir. 1958); United States v. Carruthers, 219 F.2d 21, 24-25 (9th Cir. 1955); Flanders, 172 F. Supp. at 950; First Nat'l Bank of Princeton v. United States, 136 F. Supp. 818, 824 (D.C.N.J. 1955); Rouverol v. Comm'r, 42 T.C. 186, 194 (1964), nonacq., $1965-2$ C.B. 3. But see Am. Chem. Paint Co. v. Smith, 131 F. Supp. 734, 739 (D.C. Pa. 1955)

63. For early cases holding that transfers were sales despite cancellation rights, see Comm'r v. Celanese Corp., 140 F.2d 339, 341-42 (D.C. Cir. 1944); First Nat'l Bank of Princeton, 136 F. Supp. at 824; Myers v. Comm'r, 6 T.C. $258,265-66$, acq., 1958-2 C.B. 3. But see Blake v. Comm'r, 615 F.2d 731, 734-35 (6th Cir. 1980), rev'g 67 T.C. 7 (1976).

64. For early cases holding that transfers were sales despite sublicensing restrictions, see Rollman, 244 F.2d at 641; Crook, 135 F. Supp. at 253.

65. For early cases holding that transfers were sales despite such retention rights, see Watson, 222 F.2d at 689; Celanese Corp., 140 F.2d at 341-42; Graham v. Comm'r, 26 T.C. 730, 741-43 (1956), acq., 1958-2 C.B. 3.

66. See, e.g., Celanese Corp., 140 F.2d 341-42; Comm'r v. Hopkinson, 126 F.2d 406, $411-$ 12 (2d Cir. 1942).

67. See, e.g., Bloch v. United States, 200 F.2d 63 (2d Cir. 1952) (stating that, although many substantial rights in the patent retained by plaintiff were indications of the failure to transfer absolute ownership, "the crux of the matter seems to us to be the retention of an interest in the profitable exploitation of the patented articles by receipt of a percentage of the sales price or a stated amount for each article sold," and that "[w]ithout such an interest there would be less need to keep the other rights retained here"). 
ordinary income) where the transferor received interests resembling royalties. 68 Five years later, the Service issued another ruling reiterating its position. ${ }^{69}$ In 1958, however, the Service revoked its earlier position and ruled that patent transferors could enjoy "sale" treatment (and, hence, capital gain treatment) even though consideration received is measured by production, use, or sale of the patented article. ${ }^{70}$

Without specific rules governing patent transfers, courts struggled with the attributes of patent ownership when examining individual patent agreements in their factual context. A framework slowly evolved-a framework that clearly challenged normative notions of what was and what was not a sale for tax purposes. Indeed, it was possible for a court to conclude that a patent agreement was a sale for tax purposes, even though the agreement was titled "License Agreement," the parties therein were designated "Licensor" and "Licensee," the agreement contained geographical limitations and field-of-use and other restrictions, and the agreement called for "royalty" payments contingent on the use or exploitation of the patent by the transferee. ${ }^{7 f}$ In light of the inherent factual nature of the "sale versus license" distinction, in general, and the unique characteristics of patent ownership, in particular, there was a need for a set of predictable tax rules.

\section{SOURCES OF EARLY DISSONANCE BETWEEN THE INTELLECTUAL PROPERTY AND TAXATION REGIMES}

\section{A. ACCEPTING INTELLECTUAL PROPERTY AS PROPERTY}

Different types of intellectual property rights were treated as property by courts in the late nineteenth century. For example, in 1868 , the court in Peabody v. Norfolk recognized that a trade secret is property. ${ }^{72}$ And later the U.S. Supreme Court held that a

68. Mimeograph 6490, C.B. $1950-1,9$ ("[W] agreement whereby, in consideration of the assignment of the patent, or the license of the exclusive right to make, use, and sell a patented article, the assignee or licensee agrees to pay to the assignor or licensor an amount measured by a fixed percentage of the selling price of the article so manufactured and sold, or amounts per unit based upon units manufactured or sold, or any other method measured by production, sale, or use either by assignee or licensee, or amounts payable periodically over a period generally coterminous with the transferee's use of the patent, such agreement, for income tax purposes, is to be regarded as providing for the payment of royalties taxable as ordinary income.").

69. Rev. Rul. $55-58,1955-1$ C.B. 97

70. Rev. Rul. $58-353,1958-2$ C.B. 408.

71. E.g., Watson v. United States, 222 F.2d 689 (10th Cir. 1955).

72. See Peabody v. Norfolk, 98 Mass. 452, 458 (1868) ("If he invents or discovers, and keeps secret, a process of manufacture, whether a proper subject for a patent or not, he has not indeed an exclusive right to it as against the public, or against those who in good faith acquire knowledge of it; but he has a property in it, which a court of chancery will protect against one who in violation of contract and breach of confidence undertakes to apply it to his own use, or to disclose it to third persons.") (emphasis added); Eastman Co. v. Reichenbach, 20 N.Y.S. 110, 111, 115 (Sup. Ct. 1892), aff'd, 29 N.Y.S. 1143 (Sup. Ct. 1894); see also Luckett v. Orange Julep Co., 196 S.W. 740, 743-44 (Mo. 1917) (citing cases for the established law that a trade secret is property). 
regulation requiring the disclosure of a trade secret was a taking of property in violation of the Fifth Amendment. ${ }^{73}$ Courts have long recognized patents as property. ${ }^{74}$ Providing property rights in patents encourages efficient investment and leads to more innovations. ${ }^{75}$ Similarly, early court decisions routinely held that copyrights were property. ${ }^{76}$ Courts relied on authorities dating back to the Statute of Anne that recognized copyrights as property. ${ }^{77}$ Regarding trademarks, courts in early years held that trademarks were "a distinct property, separate from the article created by the original producer" and could be transferred together with the associated establishment. ${ }^{78}$ In these early decisions, courts observed

73. See Ruckelshaus v. Monsanto Co., 467 U.S. 986, 1002-04 (1984); Philip Morris, Inc. v. Reilly, 312 F.3d 24, 45-47 (1st Cir. 2002) (en banc) (holding that a state regulation requiring disclosure of the content of cigarettes was a taking of trade secrets); see also E. I. du Pont de Nemours \& Co. v. United States, 288 F.2d 904, 912 (Ct. Cl. 1961) (holding the nonexclusive transfer of a trade secret was a sale subject to capital gains tax treatment, DVD Copy Control Ass'n v. Bunner, 75 P.3d 1, 14 (Cal. 2003) (holding that trade secrets represent a "constitutionally recognized property interest in [information]"); 1 RogER M. MILGRIM, MILGRM ON TRADE SECRETS $\S 2.01$, at 2-11 (2000) (stating that "[p]ractically all jurisdictions have recognized that a trade secret is property" at least in certain senses); Miguel Deutch, The Property Concept of Trade Secrets in Anglo-American Law: An Ongoing Debate, 31 U. RICH. L. REV. 313 (1997) (offering a critical analysis of trade secret history).

74. Stuart v. City of Easton, 170 U.S. 383, 392 (1898) ("[W]e find a recital in the patent that it is conveyed upon a named consideration, and the patent expressly refers to the act of the assembly as the authority from which the patentees derived the power to take and hold the property."); Butterworth v. United States ex rel. Hoe, 112 U.S. 50, 59 (1884) ("The legislation based on this provision regards the right of property in the inventor as the medium of the public advantage derived from his invention; so that in every grant of the limited monopoly two interests are involved: that of the public, who are the grantors, and that of the patentee."); Wilson v. Rousseau, 45 U.S. (4 How.) 646, 674-75 (1846) ("[U]nless the executor or administrator is permitted to take the place of the patentee in case of his death, and make application for the grant of the second term, which continues the exclusive enjoyment of the right of property in the invention, the object of the statute will be defeated, and a valuable right of property, intended to be secured, lost to his estate."); Wheaton v. Peters, 33 U.S. (8 Pet.) 591, 658 (1834) ("And yet it has never been pretended that the latter could hold, by the common law, any property in his invention, after he shall have sold it publicly.").

75. See Festo Corp. v. Shoketsu Kinzoku Kogyo Kabushiki Co., 535 U.S. 722, 730-31 (2002) ('The patent laws 'promote the Progress of Science and useful Arts' by rewarding innovation with a temporary monopoly. The monopoly is a property right; and like any property right, its boundaries should be clear. This clarity is essential to promote progress, because it enables efficient investment in innovation.").

76. See, e.g., Wheaton, 33 U.S. (8 Pet.) at 692 ("The title, and this section of the act, obviously consider and treat this copyright as property; something that is capable of being transferred; and the right of the assignee is protected equally with that of the author."). The Court in Wheaton noted that the state of Virginia "in the year 1785, passed a similar law, for securing to authors of literary works, an exclusive property therein, for a limited time." Id. at 683 ; see also Folsom v. Marsh, 9 F. Cas. 342, 348 (C.C.D. Mass. 1841) (No. 4,901) (Story, J.) ("The entirety of the copyright is the property of the author, and it is no defence, that another person has appropriated a part, and not the whole, of any property."); Bartlett v. Crittenden, 2 F. Cas. 967, 970 (C.C.D. Ohio 1849) (No. 1,076) ("Bartlett's right of property in his manuscript may be transferred or abandoned, the same as any other right of property.").

77. See Wheaton, 33 U.S. (8 Pet.) at 697 ("The language in the Statute of Anne, which is considered as vesting the right, is the same as in the act of congress.").

78. See Kidd v. Johnson, 100 U.S. 617,620 (1879) ("As distinct property, separate from the article created by the original producer or manufacturer, it may not be the subject of sale. But when the trade-mark is affixed to articles manufactured at a particular establishment and acquires 
that trademarks were valuable to the owners because they signified the quality of the goods or services and assured the public that the goods or services offered were the genuine product of the manufacturers and owners.

Although it was well-established that intellectual property was property, many early tax cases struggled to identify when intangible intellectual property rights constituted separable property for tax purposes. Such a determination is critical in numerous tax contexts. For example, application of the assetcapitalization rule to intellectual property development costs hinged on whether the research activity resulted in an identifiable asset. Application of early tax depreciation rules to intellectual property acquisition costs centered on whether an intangible asset existed and whether, in a business acquisition, the value of the intangible was reasonably determinable. The "property" question is central to determining the property tax treatment of any disposition. For instance, preferential capital gain treatment requires a sale of a capital asset. $^{80}$ If one could not first conclude that the object of a transfer was property, then how could there be a sale — much less a sale of a capital assetfor tax purposes?

As described in this Part, the government and courts often struggled with the competing concepts of property that could yield different tax results. In some cases, courts and tax authorities cleverly avoided the property issue when resolving a particular tax question, which did nothing to guide future decisions. In some transactional contexts, the approach adopted was to declare attributes of intellectual property ownership irrelevant and to instead focus on the tangible medium embodying the intellectual property.

a special reputation in connection with the place of manufacture, and that establishment is transferred either by contract or operation of law to others, the right to the use of the trade-mark may be lawfully transferred with it."). In later years, courts permitted transfers of trademarks together with the associated goodwill, without the need for transfers of the business. See generally JA Apparel Corp. v. Abboud, 568 F.3d 390 (2d Cir. 2009); E. \& J. Gallo Winery v. Gallo Cattle Co., 967 F.2d 1280, 1289 (9th Cir. 1992) (citing Money Store v. Harriscorp Fin., Inc., 689 F.2d 666, 676 (7th Cir. 1982)) (noting that for a trademark assignment to confer rights on the purchaser, goodwill must accompany the assignment, but "[i]t is not necessary that the entire business or its tangible assets be transferred"); accord Visa, U.S.A., Inc. v. Birmingham Trust Nat'1 Bank, 696 F.2d 1371, 1375 (Fed. Cir. 1982) ("A valid transfer of a mark, however, does not require the transfer of any physical or tangible assets. All that is necessary is the transfer of the goodwill to which the mark pertains."). For another early decision mentioning trademarks as property, see Mfg. Co. v. Trainer, 101 U.S. 51, 66-67 (1879) ("Trade-marks usually exhibit some peculiar device, vignette, or symbol, in addition to the name of the party, which the proprietor had a perfect right to appropriate, and which, as well as the name, is intended as a declaration to the public that the article is his property.").

79. See Manhattan Med. Co. v. Wood, 108 U.S. 218, 222-23 (1883) ("Any one has as unquestionable right to affix to articles manufactured by him a mark or device not previously appropriated, to distinguish them from articles of the same general character manufactured or sold by others. He may thus notify the public of the origin of the article, and secure to himself the benefits of any particular excellence it may possess from the manner or materials of its manufacture. His trade-mark is both a sign of the quality of the article and an assurance to the public that it is the genuine product of his manufacture. It thus often becomes of great value to him, and in its exclusive use the court will protect him against attempts of others to pass off their products upon the public as his. This protection is afforded not only as a matter of justice to him, but to prevent imposition upon the public.") (citing Trainer, 101 U.S. at 54).

80. See MILlER \& MAINE, supra note 54, at 220. 
In the marketplace, copyrights could be divided and the exclusive rights to copyrighted works in one medium of publication could be sold separately. ${ }^{81}$ Likewise, trademarks could be divided into separately transferable fractions according to the usage of the market in which the trademarked goods move. ${ }^{82}$ For tax purposes, however, should these marketplace concepts of property (the splitting up of bundles of rights) be accepted, or should traditional property concepts (the law relating to the passage of title) be adopted? In determining the appropriate tax result of a particular intellectual property transfer, the competing concepts of property could lead to different results. While there was much initial uncertainty and litigation over the divisibility of copyrights, trademarks, and trade names for tax purposes, most courts eventually focused on ownership of beneficial interests as opposed to legal title.

In the case of copyrights, the Service and some courts initially adopted the view that a copyright was not divisible into separable properties and that a grant of less than all the rights conferred by a copyright was not a sale for tax purposes but rather a license. ${ }^{83}$ In one case involving an assignment of the exclusive motion picture rights to a play that the taxpayer had created, the Second Circuit adhered to traditional property concepts, stating:

When ... the assignee acquires less than the sum of all the rights which together make up the copyright which as a whole is property and may be conveyed as such, ... the so-called assignment amounts only to a license. . . Unless the assignment conveys to the assigned the title to the copyright, no sale of property is made. ${ }^{8}$

Some courts later accepted market concepts and held that a copyright was

81. The Copyright Act of 1976 lists important rights of copyright ownership and provides that these rights may be subdivided. See 17 U.S.C. § 106 (2006); see also id. § 201(d)(2) (providing that "[a]ny of the exclusive rights comprised in a copyright, including any subdivision of any of the rights specified by section 106, may be transferred as provided by clause (1) and owned separately. The owner of any particular exclusive right is entitled, to the extent of that right, to all of the protection and remedies accorded to the copyright owner by this title"). Under substantive copyright law, "[c]opyright protection subsists ... in original works of authorship fixed in any tangible medium of expression" including "(1) literary works; (2) musical works, including any accompanying words; (3) dramatic works, including any accompanying music; (4) pantomimes and choreographic works; (5) pictorial, graphic, and sculptural works; (6) motion pictures and other audiovisual works; (7) sound recordings; and (8) architectural works." Id. § 102(a).

82. See New York \& Rosendale Cement Co. v. Coplay Cement Co., 45 F. 212, 212-13 (C.C.E.D. Pa. 1891) ("In holding that it is necessary to the validity of a trade-mark or trade-name that the claimant of it must be entitled to an exclusive right to it, or property in it, we do not mean to say that it may not belong to more than one person, to be enjoyed jointly or severally. Copartners, upon a dissolution of partnership may stipulate that each of them may use the trademarks of the firm, and there may be many other cases of joint and several ownership; but such coowners will together be entitled to the exclusive use of the trade-mark, and perhaps each of them will be entitled to such exclusive use as to all other persons except their associates in ownership."); Gary H. Moore, Joint Ownership of Intellectual Property: Issues and Approaches in Strategic Alliances, 1260 PLI/CORP 313, 321 (2001) (discussing the practice of several owners owning the same trademark in different fields of use).

83. For the Service's view, see I.T. 2735, 12-2 C.B. 131 (1933). For one court's view, see Goldsmith v. Comm'r, 143 F.2d 466, 467 (2d Cir. 1944), aff'g 1 T.C. 711 (1943).

84. Id. at 467. 
divisible for tax purposes. ${ }^{85}$ And the Service later conceded, ruling that a grant (for a lump sum payment) of the exclusive right to exploit a copyrighted work "in a medium of publication throughout the life of the copyright transfers a property right" and is a sale for tax purposes. ${ }^{86}$

In the case of trademarks and trade names, a similar debate occurred over divisibility and appropriate concepts of property. The monopoly a trademark or trade name owner is granted by the government is a property right. Such right may be assigned or transferred, for example, in a limited territory. Should such a grant, which does not dispose of the entire property of the grantor, be treated as a sale or a license for tax purposes? Courts addressing this particular issue generally concluded that sale treatment was proper, even though the grantor retained naked, legal title. ${ }^{87}$

In some difficult cases, courts avoided the property question when resolving a particular tax conflict involving intellectual property. Consider the issue of whether the assignment of an abstract idea should be entitled to preferential capital gain treatment. The Code defines a "capital gain" as gain from the "sale or exchange" of a "capital asset." 88 Since 1950, the Code has specifically excluded from the definition of capital asset "a copyright, a literary, musical, or artistic composition, ... or similar property, held by a taxpayer whose personal efforts created such property." 89

In Regenstein $v$. Commissioner, the taxpayer, an insurance agent, developed an idea or plan for selling group life insurance to federal government employees. ${ }^{90}$ He sold his plan to an insurance company for $\$ 10,000$. The issue before the court was whether that amount was taxable as ordinary income (the government's argument) or as capital gain (the taxpayer's argument). ${ }^{91}$ The court concluded that the amount was taxable as ordinary income because the payment was for services rendered by the taxpayer to the life insurance companies. ${ }^{92}$ Although the court expressed doubt as to whether the taxpayer's

85. See Gershwin v. United States, 153 F. Supp. 477, 480 (Ct. Cl. 1957) (holding that the transaction was "a sale of a portion of [the] decedent's rights in the musical composition"); Herwig v. United States, 105 F. Supp. 384,389 (Ct. Cl. 1952) (holding that the transfer to a film corporation constituted a sale of all the plaintiff's motion pictures rights in the novel).

86. Rev. Rul. 54-409, 1954-2 C.B. 174 (emphasis added). It should be noted that the Service's ruling applied only if the consideration received was not contingent (i.e., "measured by a percentage of the receipts from the sale, performance, or publication of the copyrighted work, [wa]s not measured by the number of copies sold, performances given, or exhibitions made of the copyrighted work, and [wa]s not payable periodically over a period generally coterminous with the grantee's use of the copyrighted work"). Id.

87. See, e.g., Rainier Brewing Co. v. Comm'r, 7 T.C. 162, 174 (1946), aff'd per curiam, 165 F.2d 217 (9th Cir. 1948); Seattle Brewing \& Malting Co. v. Comm'r, 6 T.C. 856, 871, aff d per curiam, 165 F.2d 216 (9th Cir. 1946) ("We see no inhibition, where a corporation owns a trade name, to its assigning a right to use that name in a designated territory for a price, and if the right to use is perpetual and exclusive it is more consistent with the idea of a sale than a lease, particularly where it is not dissociated from the business or merchandise with which it has been used.").

88. Id. $\S 1222(3)(2006)$.

89. See I.R.C. $\$ 1221$ (a)(3)(A), discussed infra notes $210-12$ and accompanying text.

90. 35 T.C. $183(1960)$

91. See id. at 183 .

92. See id. at 190. 
idea could be considered property, it specifically left the issue undecided and instead focused on whether the payment was for services rendered by the taxpayer. $^{93}$

In a similar case, Cranford $v$. United States, the taxpayer conceived and invented a format or structure for a radio program. ${ }^{94}$ The taxpayer, who was unable to obtain a copyright on either the radio program or the essential feature of the proposed program, subsequently assigned and conveyed all of his title and interest in the radio program, conceived and invented by him, to an unrelated company in return for a percentage of payments received by the company in connection with the licensing of the use of the program. The tax issue before the court was whether these payments were taxable as ordinary income (the government's argument) or as capital gains (the taxpayer's argument). ${ }^{95}$ Despite the government's contention that the taxpayer's format or idea was not property, the court instead focused at length on whether the radio format was a capital asset; specifically, the court addressed whether the radio format was "similar" to literary, musical, or artistic compositions and, as such, within the capital asset exclusion. ${ }^{96}$ The taxpayer argued that his "format" was not copyrightable and was not one of the specifically named items, and thus, the format was not excluded from the definition of a capital asset. ${ }^{97}$ The court rejected the taxpayer's argument and held that the format was not a capital asset. ${ }^{98}$

The courts in Regenstein and Cranford found a way to resolve the tax disputes at issue but provided an inappropriate framework for similar future cases. A preliminary issue in each case should have been whether the ideas constituted property. If they were incapable of being property held by the taxpayer, then how could there have been a sale - much less a sale of a capital asset?

The Service avoided the property issue in determining the tax consequences of using intellectual property in corporate capitalizations. The transfer of intellectual property to a corporation in exchange for stock in that corporation is potentially a taxable event. ${ }^{99}$ But a special Code provision, section 351 , provides that no gain or loss shall be recognized upon the transfer by one or more persons of property to a corporation solely in exchange for stock in such

93. See id. ("While there exists grave doubt here whether petitioner's plan or idea was one that could be considered to be property, and, further, if it were considered property, whether it would not come within the exclusion of property similar to a copyright, literary, musical, or artistic composition, we need not decide these questions, since in our view the facts taken as a whole support respondent's contention that the payment was for services rendered . . . to Metropolitan and its associated companies.") (citations omitted).

94. 338 F.2d 379 (Ct. Cl. 1964).

95. Id. at 380 .

96. Id. at 382 .

97. Id. at 381 .

98. Id at 384 .

99. The receipt of stock in exchange for property is a realization event for tax purposes, with the amount of gain realized equaling the value of the stock received minus the adjusted basis of the property exchanged. I.R.C. $\S 1001$ (a). As a general rule, the gain is reportable unless an exception is provided in the Code. Id. $\S 1001(\mathrm{c})$. 
corporation if, after the exchange, such person or persons are in control of the corporation. ${ }^{100}$ An important requirement for nonrecognition treatment under section 351 is that property must be transferred by the shareholder to the corporation. An issue that arose was whether intangibles, such as technical know-how, constituted property that could be transferred to a corporation without gain recognition under section $351 .^{101}$

In Revenue Ruling 64-56, the Service took the position that the transfer of "all substantial rights" in technical know-how would be treated as a transfer of property for purposes of section 351 of the Code. ${ }^{102}$ Soon after announcing its position, the Service was asked to address whether a nonexclusive license of a patent was property under section 351. In Revenue Ruling 69-156, the taxpayer granted certain patent rights in a chemical compound to its foreign subsidiary corporation in exchange for stock in the subsidiary, retaining for itself the substantial rights to import, use, and sell the chemical compound in the country in which the subsidiary operated. ${ }^{103}$ The Service concluded that the transferee subsidiary did not have all substantial rights in the patent, and, therefore, the grant of the patent rights did not constitute a transfer of property within the meaning of section 351 . ${ }^{\text {P0 }}$

In these rulings, the Service skirted the issue of whether intangibles were property under section 351 and instead focused on whether the grant of intangibles would constitute a sale rather than a license for capital gain purposes (i.e., whether the grant consisted of all substantial rights). In the Service's view, if a transaction did not qualify as a sale for capital gain purposes, it could not be a transfer of property for section 351 purposes. One court was quick to eschew this approach. In E. I. Du Pont de Nemours \& Co. v. United States, the United States Court of Claims held that a nonexclusive license of patents was property covered by section 351. ${ }^{105}$ Determining that section 351 was an autonomous provision, the court declared capital gain concepts (in particular, the sale versus license distinction) irrelevant. ${ }^{106}$ In holding that the nonexclusive license was property, the court stated: "Both patents themselves and the exclusive licensing of patents have long been considered 'property' under 351. It is not a far step to include a non-exclusive license of substantial value-commonly thought of in the commercial world as a positive business asset." 107 A few years after Du Pont, the Service changed its position, stating that it no longer believed that "all substantial rights in 'know-how' or a patent held by the transferor must be transferred in order to constitute the transfer of property for purposes of [section] 351.", 108

100. Id. $\S 351$ (a).

101. Rev. Rul. $64-56,1964-1$ C.B. 133.

102. Id.

103. Rev. Rul. 69-156, 1969-1 C.B. 101.

104. Id.

105. 471 F.2d 1211, 1218 (Ct. Cl. 1973).

106. Id. at $1217-18$

107. Id. at 1218

108. See I.R.S. Gen. Couns. Mem. 36,922 (Nov. 16, 1976). 


\section{B. RECONCILING SUBSTANTIVE DIFFERENCES AMONG INTELLECTUAL PROPERTIES}

The four traditional forms of intellectual property share some common characteristics. ${ }^{109}$ They are all intangible personal property; they have no physical form. ${ }^{110}$ One cannot really touch them and feel them as one can touch land and feel the texture of the soil 111 They generally depend on physical forms for their creative existence. ${ }^{112}$ For a modern example, the trademark Coca-Cola written on this page has only slight meaning, but when it appears on a red beverage can, it becomes a powerful symbol of a globally recognized product. ${ }^{113}$ Likewise, the copyright for Dan Brown's The Da Vinci Code requires either a book, $\mathrm{CD}$, or other tangible medium embodying the words of the novel. ${ }^{114}$ The patent for Viagra needs the actual pills to carry out the potent effects claimed by the pharmaceutical company. ${ }^{115}$ The trade secret in the soft drink Coca-Cola is embodied in the brown liquid flowing from the

109. See 1 J. Thomas MCCarthy, McCarthy on Trademarks and UnfaIR COMPETTIION $\S 6: 4$ (4th ed. 1997) ("That there are many common characteristics of patents, trademarks and copyrights cannot be denied. They all share the attributes of personal property, and are referred to en masse as 'intellectual property' or 'proprietary rights." ); see also XuanThao N. Nguyen, Bankrupting Trademarks, 37 U.C. DAvIS L. REV. 1267, 1297-98 (2004) (describing the common characteristics between trademarks and other types of intellectual property such as patents, copyrights, and trade secrets).

110. See Xuan-Thao Nguyen, Collateralizing Intellectual Property, 42 GA. L. REv. 1, 34 n.180 (2007) (noting that there is no physical form of intellectual property collateral for the secured party to seize when the debtor defaults on the loan); Jeanne L. Schroeder, Umatural Rights: Hegel and Intellectual Property, 60 U. MLAMI L. REV. 453, 499 (2006) (observing that the "objects of intellectual property have no separate, natural, empirical existence. They 'exist' contingently and only insofar as not only their creator, but also other subjects, recognize them as such."); Kyle Lundeen, Note, Searching for a Defense: The Google Library Litigation and the Fair Use Doctrine, 75 UMKC L. REV. 265, 280 (2006) (noting that intellectual property has no physical form).

111. See Darren Hudson Hick, Finding a Foundation: Copyright and the Creative Act, 17 Tex. InTELL. PRoP. L.J. 363, 377 (2009) (noting that "[u]nlike physical property, intellectual property is not something one can trespass upon").

112. See Dan L. Burk, Legal and Technical Standards in Digital Rights Management Technology, 74 FORDHAM L. REV. 537, 538 (2005) (stating that intellectual property is generally "embodied in particular physical forms - on paper, on canvas, on magnetic or optical media - that can be guarded from a physical theft").

113. See Justin E.D. Daily, Intellectual Property for a Wired World, 11 APR BUs. L. TODAY 43,45 (2002) ("There are relatively few people in this world who do not recognize the Nike swoosh or the Coca-Cola calligraphy."); Avi J. Stachenfeld \& Christopher M. Nicholson, Blurred Boundaries: An Analysis of the Close Relationship Between Popular Culture and the Practice of Law, 30 U.S.F. L. REv. 903, 906 (1996) (noting Coca-Cola among the few powerful symbols recognized globally).

114. See Raymond Shih Ray $\mathrm{Ku}$, The Creative Destruction of Copyright: Napster and the New Economics of Digital Technology, 69 U. CHI. L. REV. 263, 270 (2002) (analogizing that the distribution of "copyrighted works in the form of books, CDs, and videos was similar to the distribution of wine" to the public).

115. See Meika loe, The Rise of Viagra: How the Little Blue Plll Changed Sex in AMERICA 15 (2004) (observing that after five years of Viagra introduction to the public, the drug "continued to net over a billion dollars a year"); Gardiner Harris, Pfizer Reports China Has Lifted Its Viagra Patent, NYTimes.com (July 8, 2004), http://www nytimes.com/2004/07/08/business/pfizer-reports-china-has-lifted-its-viagrapatent html (reporting on patent protection for Viagra and rampant imitations of Viagra in violation of the patent in Asia). 
tin can or bottle into our bodies to satisfy our thirst and enhance our enjoyment. $^{116}$

These four types of intellectual property, though we cannot see them, touch them, or feel them, are everywhere. ${ }^{117}$ They exist wherever the physical or digital forms embodying them are transported and in existence. ${ }^{118}$ We can find a can of Coca-Cola, a pill of Viagra, or a book copy of The Da Vinci Code in China, Ukraine, Brazil, France or anywhere else in the world, even in outer space, if the owners take them there. ${ }^{11}$

These four types of intellectual property (the trademark Coca-Cola, the Viagra patents, the trade secrets in the Coca-Cola drink, and the copyright for The Da Vinci Code) can easily be duplicated, multiplied, and distributed worldwide. ${ }^{120}$ The intellectual property owners or authorized licensees and distributors can copy manufacture, and distribute the products covered by the trademark, ${ }^{121}$ patent, ${ }^{122}$ copyright, ${ }^{123}$ and trade secret. ${ }^{124}$

116. See Chris Mercer, Three Charged over Coca-Cola Trade Secrets Theft, DAILY BEVERAGE (July 6, 2006), http://www.beveragedaily.com/Industry-Markets/Three-charged-overCoca-Cola-trade-secrets-theft (reporting that the FBI and Coca-Cola caught three people involved in trade secret theft of Coca-Cola product in liquid containers); Indictment Handed Down in Coca-Cola Trade Secret Case, Atlanta Bus. Chron., (July 12, 2006, 12:17 AM), http:/atlanta.bizjournals.com/atlanta/stories/2006/07/10/daily23 html (detailing the Coca-Cola trade secret theft indictment).

117. See Lorin Brennan, Financing Intellectual Property Under Revised Article 9: National and International Conflicts, 23 HAstings CoMM. \& ENT. L.J. 313, 356 (2001) ("Intellectual property, as an intangible, has no fixed situs. It is simultaneously everywhere....").

118. See Xuan-Thao Nguyen, Holding Intellectual Property, 39 GA. L. REv. 1155, 1185-86 (2005) (observing the intangible nature of intellectual property); Tyler T. Ochoa, Copyright, Derivative Works and Fixation: Is Galoob a Mirage, or Does the Form(Gen) of the Alleged Derivative Work Matter?, 20 SANTA ClaRA COMPUTER \& High TECH. L.J. 991, 995-96 (2004) (noting that a work of authorship, an intangible property protected under copyright law, is separate from the tangible object in which work is fixed).

119. See Phil Mooney, Coke in Space, Coca-Cola Conversations Blog (Feb. 29, 2008, 11:34 EST), http://www.coca-colaconversations.com/my_weblog/2008/02/coke-in-space $\mathrm{html}$; see also The New World of Coca-Cola, CocA-CoLA, http://www.thecocacolacompany.com/presscenter/presskit_nwocc_facts html (last visited Oct. 20,2010).

120. See Abraham Bell \& Gideon Parchomovsky, Reconfiguring Property in Three Dimensions, 75 U. CHI. L. REv. 1015, 1047-48 (2008) (observing that the intellectual property law regime recognizes and protects the rights in the "intangible" assets which are apart from the physical embodiments that are used for marketing purposes); Warren E. Agin \& Scott N. Kumis, A Framework for Understanding Electronic Information Transactions, 15 ALB. L.J. SCI. \& TECH. 277 , 309-313 (2005) (discussing intellectual property rights and their wide range of embodiments)

121. See K Mart Corp. v. Cartier, Inc., 486 U.S. 281, 326-27 (1988) (Scalia, J., concurring in part and dissenting in part) (noting that "a firm that used its trademark in one business, say manufacturing cola syrup, could transfer rights to use the trademark in another business, such as bottling cola-flavored soda"); see also Coca-Cola Bottling Co. v. Coca-Cola Co., 269 F. 796, 806-08 (D. Del. 1920); Hamilton-Brown Shoe Co. v. Wolf Bros. \& Co., 240 U.S. 251, 272 (1916) ("The right to use a trademark is recognized as a kind of property, of which the owner is entitled to the exclusive enjoyment to the extent that it has been actually used.").

122. The owner of a patent can license its patent to a third party for commercial exploitation, as it so wishes. "Compulsory licensing is a rarity in our patent system." Dawson Chem. Co. v. Rohm \& Haas Co., 448 U.S. 176, 215 (1980) (noting "the long-settled view that the essence of a patent grant is the right to exclude others from profiting by the patented invention").

123. See N.Y. Times Co. v. Tasini, 533 U.S. 483, 495-96 (2001) (stating that "[t]he 1976 [Copyright] Act recast the copyright as a bundle of discrete "exclusive rights" "under 17 U.S.C. $\S$ 106 and provided that each " may be transferred ... and owned separately"); see also Fox Film 
The four types of intellectual property, though their physical embodiments are everywhere, share some similarities with respect to exclusivity rights. ${ }^{125}$ That means, if one person, group, or company has the right, no others can have it. ${ }^{126}$ For example, the owner of a trademark has the right to exclude others from using an identical or similar trademark for the same or similar products or services if the use is likely to cause consumer confusion. ${ }^{127}$ The owner of a patent can exclude others from using, making, selling, or exporting the patented products. ${ }^{128}$ The owner of a copyright has the exclusive rights to make copies, prepare derivative works, distribute the copyrighted work, publicly perform the work, and publicly display the work. ${ }^{129}$ The owner of a trade secret can bring a misappropriations case against others for unauthorized use of its trade secret.

Despite their similarities, there are many differences among these four types of intellectual property. Patents and copyrights are unique. Both patents and copyrights are specific grants dictated by the U.S. Constitution to promote the progress of science and the useful arts. ${ }^{131}$ The constitutional mandate for

Corp. v. Doyal, 286 U.S. 123, 127 (1932) ("The owner of the copyright, if he pleases, may refrain from vending or licensing and content himself with simply exercising the right to exclude others from using his property.").

124. See Dresser-Rand Co. v. Virtual Automation Inc., 361 F.3d 831, 837 (5th Cir. 2004) (noting provision in the license agreement to protect the trade secret in the sale and distribution of the products).

125. The exclusive rights for intellectual property have been observed as "worthless unless an owner remains vigilant in the policing of potential infringers." Jennifer A. Crane, Riding the Tiger: A Comparison of Intellectual Property Rights in the United States and the People's Republic of China, 7 CHI.-Kent J. INTELL. PROP. 95, 104 (2008).

126. See Benjamin K. Sovacool, Placing a Glove on the Invisible Hand: How Intellectual Property Rights May Impede Innovation in Energy Research and Development (R\&D), 18 ALB. L.J. SCI. \& TECH. 381, 390 (2008) (stating that the most salient characteristic of intellectual property is the negative right, "setting exclusive rights to particular parties and excluding others from infringing on their monopoly. Such exclusive rights can be generally transferred, licensed . ..."). With respect to patents, "[i]f granted, a patent provides a right to exclude others from practicing an invention." Engage, Inc. v. Jalbert (In re Engage, Inc.), 544 F.3d 50, 53-54 (1st Cir. 2008). The court further observes that "[t]his exclusive right is 'a species of property . . . of the same dignity as any other property which may be used to purchase patents." Id. (quoting Transparent-Wrap Mach. Corp. v. Stokes \& Smith Co., 329 U.S. 637, 643 (1947) (alteration in original)).

127. See Peter Lee, The Evolution of Intellectual Infrastructure, 83 WASH. L. REv. 39, 39 (2008) (recognizing that "intellectual property law promotes productivity through allowing exclusive rights on refined intellectual creations such as source-identifying marks, particularized expressions, and specific inventions").

128. See eBay Inc. v. MercExchange, L.L.C., 547 U.S. 388, 392 (2006) (stating that "the Patent Act also declares that 'patents shall have the attributes of personal property,' including 'the right to exclude others from making, using, offering for sale, or selling the invention" "(citing 35 U.S.C. $\S \S 261,154(a))$.

129. See Sony Corp. of Am. v. Universal City Studios, Inc., 464 U.S. 417, 432-33 (1984) ("[T]he Copyright Act grants the copyright holder 'exclusive' rights to use and to authorize the use of his work in five qualified ways, including reproduction of copyrighted work in copies.").

130. See McRoberts Software, Inc. v. Media 100, Inc., 329 F.3d 557, 569 (7th Cir. 2003) (affirming jury verdict on copyright infringement and trade secret misappropriation); Inter Med. Supplies, Ltd. v. EBI Med. Sys., Inc., 181 F.3d 446, 458, 461-63 (3d Cir. 1999) (affirming jury verdict on trade secrets violation claims and vacating excessive damages).

131. U.S. Const. art. I, $\S 8$, cl. 8. See generally Margaret Chon, Postmodem "Progress": Reconsidering the Copyright and Patent Power, 43 DePAul L. REv. 97 (1993); Michael J. 
patents and copyrights speaks volumes as to the intent of the Founders with respect to patents and copyrights for a young nation. ${ }^{132}$ There is no constitutional mandate for trademarks and trade secrets as with patents and copyrights. ${ }^{133}$ Congress relies on the Commerce Clause of Article I, Section 8 to pass federal law on trademarks. ${ }^{134}$ Congress enacts legislation (e.g., the Economic Espionage Act of 1996) to prevent theft of trade secrets and to make such theft a federal crime. ${ }^{13}$

The legal life of a patent is dictated under the federal patent statute and lasts twenty years from the date of patent application. ${ }^{136}$ The legal life of a copyright under the federal copyright statute spans the life of the original author plus seventy years after his or her death. ${ }^{137}$ If the author is an entity, the life of the copyright is 120 years from the date of publication or 95 years from the date of registration, whichever expires first. ${ }^{138}$ For trademarks, the

Madison, Notes on a Geography of Knowledge, 77 FordHAM L. REv. 2039, 2049 (2009) (positing that "[u]nder the U.S. Constitution, the legitimacy of the enactment of patent and copyright law depends on the social (or, if you prefer, political) equation of 'Progress,' the constitutional standard, with the knowledge that the patent system supports.").

132. See Crane, supra note 125 , at 101 ("The framers of the Constitution, familiar with the limited patent, copyright, and trademark privilege system of England, altered the English practice to better reflect the new nation's pioneering spirit."); J. Wesley Cochran, It Takes Two to Tango!: Problems with Community Property Ownership of Copyrights and Patents in Texas, 58 BAYLOR L. REv. 407, 425 (2006) (stating that "President Washington urged Congress to enact legislation to protect copyrights and patents to encourage creative efforts in the new nation, and Congress responded with the passage of the first national patent and copyright statutes").

133. See Trade-Mark Act of 1870 , ch. $230, \S 79,16$ Stat. 198; Trade-Mark Act of 1881, ch. $138, \S 7,21$ Stat. 502. The Trade-Mark Act of 1870 was "[a]n Act to revise, consolidate, and amend the Statutes relating to Patents and Copyrights," and Congress relied on the Patent and Copyright Clause, U.S. Const. art. $1, \S 8, \mathrm{cl}$. 8 , to enact trademark provisions. Trade-Mark Act of 1870 , at 198. Subsequently, the Supreme Court declared that Congress lacked constitutional power to regulate trademarks under the Patent and Copyright Clause. See Trade-Mark Cases, 100 U.S. 82, 99 (1879). Thereafter, Congress used the Commerce Clause and passed federal trademark statutes.

134. U.S. Const. art. I, $\S 8$, cl. 3; see also Int'1 Bancorp, LLC v. Société des Bains de Mer et du Cercle des Étrangers à Monaco, 329 F.3d 359, 363-64 (4th Cir. 2003) (emphasizing that "commerce' under the [Lanham] Act is coterminous with that commerce that Congress may regulate under the Commerce Clause of the United States Constitution"); Irina D. Manta, Privatizing Trademarks, 51 Ariz. L. Rev. 381, 382 (2009) (restating that the Commerce Clause provides the Constitutional basis for Congress to pass federal trademark law).

135. See Jacqueline Lipton, Balancing Private Rights and Public Policies: Reconceptualizing Property in Databases, 18 BERKELEY TECH. L.J. 773, 819 (2003) (observing that the 1996 federal statute does not pre-empt state trade secret law).

136. See 35 U.S.C. $\S 154(a)(2)$ (2006) (stating that the patent term is 20 years from an effective filing date); see also David A. Balto \& Andrew M. Wolman, Intellectual Property and Antitrust: General Principles, 43 IDEA 395, 473 (2003) (posing a question between the legal life of a patent, which is 20 years from the date of filing the patent application, and the economic life of a patent ). The current legal life of a patent represents a change from seventeen years to twenty years. See C. Michael White, Why a Seventeen Year Patent?, 38 J. PAT. OfF. Soc'y 839, 840 (1956) ("Ideally the legal life of a patent should represent a balance between the additional incentive of another year and the social cost of a longer monopoly.").

137. See Thomas F. Cotter, Toward a Functional Definition of Publication in Copyright Law, 92 MinN. L. REv. 1724, 1732-34 (2008) (reviewing the statutory provision for the legal life of copyright created by natural authors and works made for hire)

138. See 17 U.S.C. $\S 302$ (2006) (providing that the copyright term is life of the natural author plus 70 years; but the work for hire duration is the earlier of 95 years from publication or 120 years from creation); Deborah Tussey, What If Employees Owned Their Copyrights?, $2008 \mathrm{MicH}$. 
legal life lasts as long as the trademark is used in commerce to identify a particular source and to distinguish the trademarked products. ${ }^{139}$ That means the life of a trademark can be one year, ten years, or one hundred years. A trade secret lasts as long as the secret is kept a secret. The trade secret ceases to have a legal life if the public learns it, causing the trade secret to lose its independent economic value; ${ }^{140}$ thus the life of a trade secret is indeterminable. ${ }^{14}$

Both patents and copyrights are grants wherein the federal government passes law that specifically recognizes exclusive rights for a limited time. ${ }^{142}$ For trademarks, both federal and state laws recognize and extend protection. ${ }^{143}$ The Lanham Act of 1946 is the authoritative federal source for trademark protection. ${ }^{144}$ States also have trademark laws to regulate, within state boundaries, trademarks and competitive conduct related to trademarks. ${ }^{14}$ There is no comprehensive federal trade secret statute akin to the federal trademark statute; ${ }^{146}$ each state has its own trade secret laws to regulate. ${ }^{147}$

ST. L. REV. 233, 234 n.6 (2008) (discussing works made for hire duration).

139. See Mark Bartholomew \& John Tehranian, The Secret Life of Legal Doctrine: The Divergent Evolution of Secondary Liability in Trademark and Copyright Law, 21 BERKELEY TECH. L.J. 1363, 1400 (2006) (stating that trademarks are different from copyrights because the term of protection is "potentially infinite" due to the duration of use by their owners).

140. See Ruckelshaus v. Monsanto Co., 467 U.S. 986, 1002 (1984) (noting that "[b]ecause of the intangible nature of a trade secret, the extent of the property right therein is defined by the extent to which the owner of the secret protects his interest from disclosure to others"); Sean D. Whaley, "I'm a Highway Star": An Outline for a Federal Right of Publicity, 31 Hastings CoMm. \& ENT L.J. 257, 272 (2009) (discussing that copyrights and patents enjoy fixed duration of protection, but trademarks and trade secrets may be valid "in perpetuity as long as certain criteria are met").

141. See Stephen I. Willis, An Economic Evaluation of Trade Secrets, 269 PLI/Pat 737, 75253 (1989) (emphasizing that the owner of a trade secret can collect royalties from a license indefinitely).

142. Fox Film Corp. v. Doyal, 286 U.S. 123, 127-28 (1932) ("A copyright, like a patent, is 'at once the equivalent given by the public for benefits bestowed by the genius and meditations and skill of individuals and the incentive to further efforts for the same important objects."') (internal citations omitted).

143. See Kathryn M. Foley, Protecting Fictional Characters: Defining the Elusive Trademark-Copyright Divide, 41 ConN. L. REV. 921, 939-40 (2009) (discussing federal and state protections for trademarks).

144. See id; Kenneth L. Port, Trademark Extortion: The End of Trademark Law, 65 WASH. \& LEE L. REV. 585, 595-600 (2008) (reviewing the history of the Lanham Act and expansion of trademark protection).

145. See Jasmine Abdel-khalik, Is a Rose by Any Other Image Still a Rose? Disconnecting Dilution's Similarity Test from Traditional Trademark Concepts, 39 U. TOL. L. REV. 591, 598-99 (2008) (noting state trademark protection against dilutive use and how Congress joined states in enacting the federal Trademark Dilution statute in 1995); Greg Lastowka, Google's Law, 73 BROOK. L. REV. 1327, 1361 (2008) (stating that "in the United States, the federal Lanham Act is the primary source of trademark protection, though state common law and statutory protections are also available").

146. See generally Miguel Deutch, The Property Concept of Trade Secrets in AngloAmerican Law: An Ongoing Debate, 31 U. RicH. L. REV. 313 (1997); Christopher Rebel J. Pace, The Case for a Federal Trade Secrets Act, 8 HARV. J.L. \& TECH. 427, 442 (1995).

147. See Preseault v. Interstate Commerce Comm'n, 494 U.S. 1, 22 (1990) (noting that "state law creates property right in trade secrets for purposes of Fifth Amendment, and regulatory regime does not pre-empt state property law"); see also Julie Piper, Comment, I Have A Secret?: Applying the Uniform Trade Secrets Act to Confidential Information that Does Not Rise to the 
Most states adopt all or parts of the model trade secret statute to recognize trade secrets and define what conduct constitutes misappropriation of a trade secret. ${ }^{148}$ Nonetheless, trade secrets are deemed to have more traditional characteristics of property than the other types of intellectual property. ${ }^{149}$

In developing various tests for analyzing intellectual property transactions, courts had to reconcile the substantive similarities and differences among the different types of intellectual property. In some contexts, tax cases emphasized the substantive similarities among the forms (e.g., grants of monopolies) and applied the case law that developed relating to one type of intellectual property to other types. ${ }^{150}$ For example, as described above, early case law established that in order for a transfer of a patent to constitute a sale for tax purposes, all substantial rights had to be transferred, and that sale treatment could result even though the consideration received by the transferor was measured by production, use, or sale of the patented article. ${ }^{151}$ Several courts later used this framework in determining whether or not the transfer of a copyright, trade secret, trademark, or trade name constituted a sale for tax purposes.

When confronted with whether a copyright assignment could be denied sale treatment solely because the purchase price took the form of contingent payments, the Service relied on its previous position with respect to contingent payments in patent assignments: "Since the property rights of patents and copyrights are similar in substance, it is concluded that the Service should adopt, in the case of copyrights, the position that is being taken in the case of patents." 153

In analyzing whether or not the transfer of a trade secret meets the sale requirement, a number of courts applied the tests that had been used in analyzing patent assignments based on the valid and important similarities between a patent and a trade secret. ${ }^{154}$ While a patent is different from a trade

Level of Trade Secret Status, 12 MARQ. InTELl. PROP. L. Rev. 359, 360 (2008) (discussing the history of state trade secret law against misappropriation).

148. See generally Michael J. Hutter, The Case for Adoption of a Uniform Trade Secrets Act in New York, 10 ALB. L.J. SCI. \& TECH. 1, 6-9 (1999) (arguing for New York to depart from following the Restatement approach to trade secret misappropriation and adopt legislation modeled after the Uniform Trade Secrets Act); Breana C. Smith et al., Intellectual Property Crimes, 43 AM. CRIM. L. REv. 663, 679 (2006) (emphasizing the criminal and civil laws available at the state level against trade secret thefts)

149. Ruckelshaus v. Monsanto Co., 467 U.S. 986, 1003-04 (1984) (holding that trade secrets, despite their intangible nature, are property rights "protected by the Taking Clause of the Fiffh Amendment"). For more "takings" analysis of trade secrets, see Philip Morris, Inc. v. Reilly, 312 F.3d 24, 30-47 (1st Cir. 2002) (en banc) (holding that state requirement of disclosure of cigarette content was a regulatory taking of trade secrets); DVD Copy Control Ass'n v. Bunner, 75 P.3d 1, 14 (Cal. 2003) (stating that trade secrets represent "a constitutionally recognized property interest in information").

150. For substantive similarities, see supra notes $109-30$ and accompanying text.

151. Id.

152. See, e.g., Leisure Dynamics, Inc. v. Comm'r, 494 F.2d 1340, 1340 (8th Cir. 1974) (applying framework to trademarks and trade names); Merck \& Co. v. Smith, 261 F.2d 162, 165 (3d Cir. 1958) (copyrights); Stalker Corp. v. United States, 209 F. Supp. 30, 33 (E.D. Mich. 1962) (trade secrets).

153. Rev. Rul. $60-226,1960-1$ C.B. 26.

154. See, e.g., Pickren v. United States, 378 F.2d 595, 599 (5th Cir. 1967) ("Secret formulas 
secret (an essential element of the latter is the right in the discoverer to prevent unauthorized disclosure), an important similarity is that "[ $t]$ he value in both lies in the rights they give to their owners for monopolistic exploitation." 155 A patent transfer meets the sale requirement only if the transferor transfers all substantial rights (e.g., the right to prevent others from operating under the patent). ${ }^{156}$ By analogy, the transfer of a trade secret constitutes a sale only if the transferor conveys his or her most important rights - "the right to prevent unauthorized disclosure and the right to prevent further use of the trade secret by all others." 157

In analyzing the tax treatment of transfers of trademarks and trade names, some courts relied on the tax law that had developed on patent transfers, although such analogies were a bit less helpful. ${ }^{158}$ If a patent transfer was considered a sale only if the transferor relinquished all substantial rights, then it would make sense that a trademark transfer should be considered a sale only if the transferor did not retain significant rights or continuing interests with respect to the transferred trademark. But what sorts of retained continuing interests should preclude sale treatment? In a typical trademark or trade name transfer, it is not uncommon for a variety of conditions to be included in the transfer agreement. The transferor may retain, for example, certain powers, rights, or continuing interests in order to maintain some operational control of the trademark or trade name (e.g., continuing to participate in employee training or conducting advertising promotions). Without any clear rules, and with only general analogies to patent cases, early disputes arose between the Service and transferors of trademarks and trade names over the tax implications of such retained powers, rights, or continuing interests; numerous courts were called upon to ascertain when varying conditions in trademark and trade name agreements were significant enough to preclude sale treatment. Some of the early cases dealing with the problem of differentiating a sale from

and trade names are sufficiently akin to patents to warrant the application, by analogy, of the tax law that has been developed relating to the transfer of patent rights, in tax cases involving transfers of secret formulas and trade names."); E. I. du Pont de Nemours \& Co. v. United States, 288 F.2d 904, 911 (Ct. Cl. 1961); Stalker Corp., 209 F. Supp. at 33 ("Whether or not the transfer of a trade secret constitutes a sale for tax purposes, the tests used in determining whether or not there has been a sale of a patent have been applied.").

155. E. I. du Pont de Nemours \& Co., 288 F.2d at 911 ("The owner of a patent can make something which no one else can make because no one else is permitted. But circumstances are frequently such that the owner of a trade secret can make something which no one else can make because no one else knows how. The patent owner has a monopoly created by law; the trade secret owner has a monopoly in fact. In both cases there exists the possibility of either limited or complete transfers of the right to the exclusive use of an idea.").

156. See Alfred E. Mann Found. for Scientific Research v. Cochlear Corp., 604 F.3d 1354, 1359 (Fed. Cir. 2010).

157. Stalker Corp., 209 F. Supp. at 34 (stating "[a] transfer of anything less results in a transaction which is not a sale under the Code").

158. See Seattle Brewing \& Malting Co. v. Comm'r, 6 T.C. 856, 870-72 (1946), aff'd per curiam, 165 F.2d 216 (9th Cir. 1948) (relying on patent cases in analyzing a trade name transfer); see also Herwig v. United States, 105 F. Supp. 384, 388 (Ct. Cl. 1952) ("Since the basic nature of copyrights, patents and trademarks is the same, i.e., grants of monopolies for a fixed period of time by the Government as a reward for the particular genius of the one receiving the grant, it would seem that the rights granted in connection with any one of them should be treated the same under the law."). 
a license involved the transfer of Dairy Queen franchises by territorial franchisors to individual subfranchisees. ${ }^{159}$ It was not uncommon for courts to reach different results on virtually identical facts. 160

At issue in many of the trademark and trade name cases was the effect, if any, of the contingent payment arrangement. As with patent and copyright transfers, transfers of trademarks and trade names frequently involve payments made by the transferee that are payable over a period of time and are contingent on production. The question was whether the contingent payment arrangement was inconsistent with the characteristics of a sale. As noted earlier in this Article, the Service was quick to resolve the issue in patent and copyright cases - the form of payment should not influence the decision as to whether a patent or copyright assignment is treated as a sale or license for tax purposes. ${ }^{161}$ The Service did not employ the same position in trademark and trade name cases, viewing the receipt of contingent payments as a continuing economic interest similar to the receipt of royalty income. There was much diversity of opinion among courts over the issue. The form of payment influenced some courts to treat the transaction as if it were a license, with the result that the payments were taxable as ordinary income. ${ }^{162}$ Some other courts did not regard the form of payment to be controlling, with the result that payments received capital gain treatment. ${ }^{163}$ Courts struggled with such questions as the following: Should contingent payment arrangements be analyzed apart from the other conditions in the agreement? Does it matter whether or not the payments were the only form of monetary consideration? Does it matter whether the transfer agreement was perpetual or not? Analogies in trademark and trade name cases to patent cases provided little guidance, highlighting the need for specific tax rules governing trademarks and trade name assets.

Courts did not always find all types of intellectual property sufficiently similar to one another to warrant providing them similar treatment under the tax laws. In considering the deductibility of attorney's fees and other litigation costs incurred in the pursuit and settlement of intellectual property

159. See Consol. Foods Corp. v. United States, 569 F.2d 436, 438-40 (7th Cir. 1978).

160. The Eighth and Ninth Circuits held that transfers were not sales for tax purposes because of the rights, powers, and continuing interests retained by the transferor. See United States v. Wernentin, 354 F.2d 757, 766 (8th Cir. 1965) (as to both lump sum and contingent payments); Moberg v. Comm'r, 310 F.2d 782, 783-84 (9th Cir. 1962) (as to three of the four forms of agreement at issue). However, the Fourth, Fifth, and Tenth Circuits - in similar transactionsfound sales to exist and allowed capital gain treatment. See Moberg v. Comm'r, 305 F.2d 800, 806 (5th Cir. 1962) (as to lump sum payments but not contingent payments); Estate of Gowdey v. Comm'r, 307 F.2d 816, 818 (4th Cir. 1962) (as to lump sum payment but not contingent payments); Dairy Queen of Okla., Inc. v. Comm'r, 250 F.2d 503, 506 (10th Cir. 1957) (as to both lump sum payment and contingent payments). For a good summary of these cases, see Consol. Foods Corp., 569 F.2d at 438-40. See also John H. Hall, Tax Aspects of Franchising Operations, in Twentieth ANNUAL Tulane Tax Instrtute 102, 111-13 (1971); Richard T. Husseman \& Robert D. Kaplan, Comment, Federal Taxation of Franchise Sales, 44 WASH. L. REV. 617, 61925 (1969).

161. See supra notes $66-70,153$ and accompanying text

162. See, e.g., Moberg, 305 F.2d at 338, 340; Estate of Gowdey, 307 F.2d at 818 .

163. See, e.g., Moberg, 310 F.2d at 784; Dairy Queen of Okla., Inc., 250 F.2d at 506. 
infringement actions, courts focused on the substantive differences among the intellectual property forms in creating tax distinctions. Under general tax principles, legal fees incurred in a business or profit-seeking context (e.g., those related to the production or collection of taxable income) are deductible unless they are considered capital expenditures. ${ }^{164}$ Regulations provide examples of nondeductible capital expenditures including the cost of acquiring property with a "useful life substantially beyond the taxable year" and "[t]he cost of defending or perfecting title to property." 165 Accordingly, attorney's fees in a suit to quiet title to land are not deductible, but attorney's fees in a suit to collect accrued rents on the land are deductible. ${ }^{166}$ To determine whether litigation costs-even if incurred in a business or profit-seeking activity - are nondeductible capital expenditures, courts focus on the claim's origin and character with respect to which the litigation costs are incurred. ${ }^{167}$ The "origin of the claim" test is not a purely mechanical test; it requires more than focusing merely on the taxpayer's intent in filing the suit. ${ }^{168}$ One must also consider "the issues involved, the nature and objectives of the litigation, the defenses asserted, the purpose for which the claimed deductions were expended, the background of the litigation, and all facts pertaining to the controversy."

Using this framework to determine the deductibility or capitalization of intellectual property litigation costs was not an easy task for courts. Should all intellectual property litigation (e.g., patent infringement, copyright infringement, and trademark infringement actions) be viewed the same for tax purposes? If the issues involved, the objectives of the litigation, and the defenses asserted in each are similar, then a standard based on the origin of the claim litigated would dictate similar tax treatment of legal costs incurred therein. "While. . . viewing all such intellectual property litigation generically" has "the unarguable appeal of expediency," it "also ignores the actual inherent differences and purposes of the various rights and remedies involved." 170 Over time, tax courts struggled to identify and reconcile the

164. See I.R.C. $\S 162$ (2000) (allowing a deduction for ordinary and necessary business expenses paid or incurred during the year in carrying on any trade or business); id. $\S 212$ (allowing a deduction for ordinary and necessary expenses paid or incurred during the year for the production or collection of income and for the management, conversation, or maintenance of property held for the production of income). But see id. $\S 263$ (providing that no deduction shall be allowed for capital expenditures).

165. Treas. Reg. § 1.263(a)-2(a), (c) (as amended in 1987).

166. Treas. Reg. $\S 1.212-1(\mathrm{k}$ ) (as amended in 1975).

167. The "origin of the claim" test was originally created by the Supreme Court in United States v. Gilmore, 372 U.S. 39, 49 (1963), and used to determine whether litigation costs were incurred in a business or profit-seeking context or whether the costs were personal. The origin of the claim standard has also been used to determine whether litigation costs - even if incurred in a business or profit-seeking activity-are nondeductible capital expenditures. Woodward v. Comm'r, 397 U.S. 572, 578-79 (1970) (holding that the origin of the claim that gave rise to the legal fees was the acquisition of stock, and thus, the fees should be capitalized).

168. See Boagni v. Commissioner, 59 T.C. 708,713 (1973), acq., 1973-2 C.B. 1.

169. Id. The origin of the claim test has been used in a number of lower court cases. See, e.g., Madden v. Comm'r, 514 F.2d 1149, 1151-52 (9th Cir. 1975); Fleischman v. Comm'r, 45 T.C. $439,444-47$ (1966).

170. I.R.S. Field Serv. Adv. Mem. 199925012 (June 25, 1999), available at 1999 WL 
distinguishing characteristics of intellectual property when determining the proper tax treatment of intellectual property litigation costs. In infringement cases, courts generally concluded that legal fees incurred in patent infringement actions were deductible. ${ }^{171}$ In contrast, legal fees incurred in trademark infringement actions were not deductible but had to be capitalized. ${ }^{172}$ The apparent distinction was that in patent and copyright infringement cases, litigation costs are incurred to recover lost profits and damages and not to remove cloud of title or defend ownership of property. ${ }^{173}$ In trademark and trade name infringement cases, litigation costs "resemble the cost of perfecting or preserving title to property, a cost well established as capital expenditures." "174

\section{ESTABLISHING SigNifiCANCE OF TANGIBLE MEDIUM EMBODYING INTELLECTUAL PROPERTY}

As described earlier, the traditional forms of intellectual property - patents, copyrights, trademarks, and trade secrets - generally depend on tangible forms for their creative existence. ${ }^{175}$ For example, the patent for a drug needs the actual pills to carry out the potent effects claimed by the patent owner and the copyright for an author's novel requires either a book, CD, or other tangible medium embodying the words of the novel. Though we cannot see, touch, or feel patents, copyrights, trademarks, and trade secrets, they are everywhere and exist wherever the tangible or digital forms embodying them are transported and in existence. They can be easily duplicated, multiplied, and distributed worldwide.

Because intellectual property depends on tangible forms for its creative existence, an important tax issue is whether tangible medium embodying intellectual property should be significant in determining the tax treatment of intellectual property. The government has not always taken a consistent approach.

In determining the tax consequences of certain intellectual property transactions, the government has largely ignored the legal attributes of intellectual property, instead deeming significant the tangible medium embodying the intellectual property. An example in which the tax treatment of a transaction depends on the tangible medium embodying intellectual property

424839.

171. See, e.g., Urquhart v. Comm'r, 215 F.2d 17, 120 (3d Cir. 1954).

172. See, e.g., Medco Prods. Co., Inc. v. Comm'r, 523 F.2d 137, 139 (10th Cir. 1975); Danskin, Inc. v. Comm'r, 331 F.2d 360, 361-62 (2d Cir. 1964). But see J.R. Wood \& Sons, Inc. v. Comm'r, 21 T.C.M. (CCH) 1038 (1962) (holding costs of unsuccessful trademark infringement currently deductible).

173. Litigation costs in patent infringement actions are deductible even though the defense of invalidity of patent claims is normally raised and disposed of first. See Urquhart, 215 F.2d at 20 21.

174. Danskin, Inc., 331 F.2d. at 361 ("The purpose and effect of the legal expenses ... was to increase the value of taxpayer's registered trademark and to make more secure taxpayer's property in it by forever eliminating the possibility of having it impaired by the competitive use of this confusingly similar mark.").

175. See supra notes $112-16$ and accompanying text. 
involves the exchange of intellectual property. As a general rule, the exchange of one type of intellectual property for a different type of intellectual property is a realization event potentially subject to taxation with the amount of gain equal to the difference between the value of the intellectual property received and the adjusted basis of the intellectual property given in the exchange. ${ }^{176}$ However a special nonrecognition rules applies to "like kind" exchanges of property. ${ }^{177}$ Specifically, no gain need be recognized if business or investment property is exchanged solely for property of a "like kind" to be held for use in business or investment. ${ }^{178}$ Under the approach adopted by the Treasury, whether intellectual property is of a like kind to other intellectual property depends not only on "the nature or character of the [intangible] rights involved (e.g., a patent or a copyright), [but] also on the nature or character of the underlying [tangible asset] to which the [intellectual] property relates." 179 Accordingly, if a taxpayer "exchanges a copyright on a novel for a copyright on a different novel," then "[t]he properties exchanged are of a like kind." 180 On the other hand, if a taxpayer exchanges a copyright on a novel for a copyright on a song," then "[t]he properties exchanged are not of a like kind." 181

A second example is the tax treatment of software development costs. One approach to software development costs would be to prescribe different tax treatments depending on the protection sought (e.g., patent, copyright, trade secret). In other words, if developed software were protected as a patent, then the development costs would be treated the same as costs of developing any patentable invention. If, on the other hand, the software were protected only as a copyright, then the development costs would be treated the same as costs of developing any copyright (e.g., copyrighted novel, copyrighted song). Without clear rules, the Service adopted a different approach-one that ignores the form of intangible intellectual protection sought and instead focuses on the subject of protection. ${ }^{182}$ Under a longstanding administrative ruling, software development costs are treated the same (i.e., currently deductible) regardless of whether the software is patented, copyrighted, or protected by trade secret. ${ }^{183}$

A third example is the tax treatment of advertising expenditures that produce intellectual property rights of a long-term nature (e.g., graphic designs, package designs). As a general rule, the government allows taxpayers to currently deduct advertising costs notwithstanding the fact that advertising often produces benefits that continue well beyond the current taxable year. ${ }^{184}$

176. I.R.C. $\S 1001$ (a) (2006) (providing the amount of gain is the excess of the amount realized over the adjusted basis of the property transferred).

177. See I.R.C. § 1031(a)(2006).

178. Id.

179. Treas. Reg. $\S 1.1031$ (a)-2(c) (as amended in 2005)

180. Id. $\S 1.1031$ (a)-2(c)(3), Ex. 1 .

181. Id. $\S 1.1031$ (a)-2(c)(3), Ex. 2

182. Rev. Proc. 69-21, 1969-2 C.B. 303, superseded and updated by Rev. Proc. 2000-50, 2000-2 C.B. 601.

183. Id.

184. After the Supreme Court's decision in INDOPCO, Inc. v. Commissioner, 503 U.S. 79 
"Only in the unusual circumstance where advertising is directed towards obtaining future benefits significantly beyond those traditionally associated with ordinary [product, institutional,] or goodwill advertising, must the costs . . be capitalized." 185 Advertising expenditures often create intellectual property rights in trademarks and trade dress (the total image and overall appearance of a product), as such rights are based on use in commerce and often encompass the costs of creating copyrightable advertising materials. An interesting question is whether these long-term intangible benefits should serve as the basis for requiring capitalization of advertising campaign expenditures. Or, should such costs be deductible because they resulted from advertising activities?

In one case, ${ }^{186}$ a tax court allowed trade dress and copyright development costs to be deducted even though such costs in a non-advertising context would most likely have to be capitalized. The taxpayer incurred substantial costs in developing an advertising campaign - namely expenses relating to the creation of graphic designs and package designs for the packaging of its cigarette products - and sought to deduct such campaign expenditures. ${ }_{188}$ The taxpayer also sought to deduct the costs of executing the campaign. ${ }^{188}$ Although the government conceded that the advertising execution expenses were deductible, it argued that the advertising campaign expenditures should be capitalized. The government's argument was that the campaign expenditures provided long-term benefits that were not traditionally associated with ordinary business advertising. The graphic design and package design costs provided legal rights and economic interests of a long-term nature-the legal rights being the statutory rights and common-law trademark rights that attach to trade dress and the economic interest being the associated brand equity. ${ }^{189}$ In addition, the taxpayer received long-term copyright protection for its copyrightable advertising materials. ${ }^{190}$ The court rejected the government's argument and held that graphic and package design costs incurred by the taxpayer were not required to be capitalized but were deductible as ordinary product advertising. ${ }^{191}$

(1992), current deductibility of advertising costs was uncertain because most advertising gives rise to long-term benefits. In Revenue Ruling 92-80, however, the Service ruled that INDOPCO, Inc. "[would] not affect the treatment of advertising costs as business expenses which are generally deductible under section 162 of the Code." Rev. Rul. 92-80, 1992-2 C.B. 57.

185. Rev. Rul. $92-80,1992-2$ C.B. 57.

186. RJR Nabisco Inc. v. Comm'r, 76 T.C.M. (CCH) 71 (1988), action on dec., 1999-012 (Oct. 4, 1999).

187. "A 'graphic design' . . . is a combination of verbal information, styles of print, pictures or drawings, shapes, patterns, colors, spacing, and the like that make up an overall visual display. The term 'package design' . . refers to the design of the physical construction of the package." Id. at 73 .

188. Advertising execution expenditures were defined by the Service as costs of executing the advertising campaign (e.g., costs of production of television commercials). Id.

189. Id. at 83 .

190. Id. at 84

191. Id. at 84-85. In a 1999 action on decision, the Service did not acquiesce to the court's decision in RJR Nabisco Inc. and announced that it would continue to litigate the treatment of package design costs where appropriate. Id., action on dec., 1999-012 (Oct. 4, 1999) ("Rev. Rul. 
In the vast majority of cases, the nature of the developed intangible benefits and the length of legal protections are significant in determining tax results. However, such legal attributes have been rendered completely irrelevant in certain contexts. As demonstrated here, a company must generally capitalize copyright development costs, but it does not have to capitalize costs if the subject of the copyright is software or if the copyright is the product of advertising activities. Relying on intellectual property attributes in some contexts and disregarding them in others creates incoherent distinctions in tax law.

\section{THREE GOALS OF SPECIFIC TAX RULES GOVERNING INTELLECTUAL PROPERTY}

Congress began enacting intellectual property tax rules in the 1950s. As a result of tax legislation over the past five decades, the Code now contains several special rules that govern different types of intellectual property. A few of the special provisions apply equally to a large group of intellectual property assets. ${ }^{192}$ Most, however, are mutually exclusive, governing specific forms of intellectual property. ${ }^{193}$ In applying these rules, it is helpful to understand as much as possible about why they exist and how they fit into or conflict with sound policy. Here, each of the special rules is described in terms of its stated policy objectives. While a few of the provisions were designed to encourage certain intellectual property activities, the vast majority of the special rules were enacted on an ad hoc basis with particular tax goals in mind: (1) to close tax loopholes and remove tax inequities, or (2) to simplify rules and eliminate tax uncertainties that existed under general tax principles.

\section{A. SUPPORTING INTELLECTUAL PROPERTY DEVELOPMENT AND ECONOMIC GROWTH}

\section{Tax Incentives for Patent Development Activities}

In a few cases, special legislation was designed to support intellectual property growth and incentivize desirable intellectual property activity. In 1954, Congress enacted two provisions primarily to encourage research activity and to stimulate economic growth and technological development. ${ }^{194}$

92-80 should not be read as a concession that package design costs are advertising and, therefore, deductible."). For the Service's position, see Rev. Proc. 2002-9, 2002-3 I.R.B. 327 (app. 3.01); Rev. Proc. 97-35, 1997-2 C.B. 448; Rev. Rul. 89-23, 1989-23, 1989-1 C.B. 85. In 2004, the Treasury Department issued regulations permitting a deduction for the costs of creating package designs. See Treas. Reg. $\S 1.263$ (a)-4(b)(3)(v) (2004) (providing that an amount paid to create a package design is not treated as an amount that creates a separate and distinct intangible asset). It should be noted that although a taxpayer can deduct the costs of developing a package design, the taxpayer must capitalize the costs of obtaining trademarks and copyrights on elements of the package design (i.e., the fees paid to a government agency to obtain trademark and copyright protection on certain elements of the package design). Id. § 1.263(a)-4(1), Ex. 9(i).

192. See, e.g. I.R.C. $\S \S 167(\mathrm{~g})(6), 170(\mathrm{e})(1)(\mathrm{B})(\mathrm{iii}), 170(\mathrm{~m}), 197(\mathrm{~d})(1)(2006)$.

193. See, e.g., id. $\S \S 41,167(\mathrm{f})(1), 167(\mathrm{~g})(8), 174,1221$ (a)(3), 1221(b)(3), 1235, 1253.

194. Id. $\$ 174$ (a) (1954) (allowing taxpayers to treat research or experimental expenditures as expenses not chargeable to capital account as long as those expenditures are paid or incurred in 
Section 174 of the Code permits taxpayers to deduct immediately certain research and development expenditures that might otherwise have to be capitalized. ${ }^{195}$ Section 1235 provides statutory assurance to certain individual inventors that the sale of their patents will qualify for reduced capital gain rates. ${ }^{196}$ More specifically, the special rule guarantees capital gain rates, as opposed to higher ordinary income tax rates, for any transfer of all substantial rights to a patent by certain holders to unrelated parties. ${ }^{197}$ Working together, these two rules permit an inventor to deduct research costs when incurred and then enjoy a low capital gains tax on the later sale of the resulting invention. ${ }^{198}$

To encourage firms to actually increase their research expenditures over time, Congress enacted a special credit. ${ }^{199}$ The credit currently found in section 41 of the Code is incremental in that it is equal to a certain percentage of qualified research spending above a base amount, which can be thought of as a firm's normal level of research and development investment. ${ }^{200}$ The credit

connection with the taxpayer's trade or business); id. $\S 263(\mathrm{a})(1)(\mathrm{B})$ (providing that the capitalization rules under section 263(a) do not apply to research or experimental expenditures deductible under section 174(a)).

195. Id.; see H.R. REP. No. 1337 (1954), reprinted in 1954 U.S.C.C.A.N. 4017, 4053; 100 CONG. REC. 3,425 (1954) (statement of Chairman Reed: "This provision will greatly stimulate the search for new products and new inventions upon which the future economic and military strength of our Nation depends. It will be particularly valuable to small and growing businesses."); see also Alexander, supra note 22, at 549 (noting a primary reason for enacting section 174 was to create an incentive for new products and inventions through federal subsidy of research and development start-ups); William Natbony, The Tax Incentives for Research and Development: An Analysis and a Proposal, 76 GEo. L.J. 347, 349 (1987) (explaining that Congress decided to provide taxpayers with the option of an immediate deduction in order to encourage new research and development); Richard L. Parker, The Innocent Civilians in the War against NOL Trafficking: Section 382 and High-Tech Start-Up Companies, 9 VA. TAX REV. 625, 694 (1990) ("The deduction election under section 174(a) is intended to encourage research and development activities by allowing the cost of such activities to be used to offset the income earned in the business at the earliest possible date.").

196. I.R.C. $\S 1235$ (2010); see S. REP. No. 83-1622, at 439 (1954), reprinted in 1954 U.S.C.C.A.N. 4621,5082 (stating a policy goal underlying section 1235 's enactment was "to provide an incentive to inventors to contribute to the welfare of the Nation").

197. I.R.C. $\S 1235$.

198. A related incentive for inventors is the exemption from the general "recapture" rules of section 1245. I.R.C. $\S 1245$ (2006). Under section 1245, any gain recognized on the disposition of intangible personal property must be reported as ordinary income - not capital gain - to the extent of any deductions (e.g., depreciation and amortization) taken with respect to the property. Id. $\S 1245$ (a)(1). In other words, any part of the gain that is attributable to depreciation or amortization deductions previously attributable to the transferred property must be recaptured as ordinary income and taxed at ordinary rates, whereas any part of the gain that is attributable to economic appreciation may be taxed at capital gains rates. See id. Although intangible personal property is generally subject to recapture, Newton Insert Co. v. Commissioner, 61 T.C. 570,587 (1974), aff'd, 545 F.2d 1259 (9th Cir. 1976), the government has clarified in an administrative pronouncement that inventions, the creation costs of which were expensed under section 174, are not subject to section 1245 recapture, Rev. Rul. 85-186, 1985-2 C.B. 84 (providing that section 174(a) deductions need not be recaptured as ordinary income on later sale). Thus, the entire amount of gain recognized by an inventor on a later sale - gain attributable to research and experimental costs expensed under section 174 , as well as gain attributable to true economic appreciation in value of the invention-may receive preferential capital gains treatment under section 1235.

199. Id. Economic Recovery Tax Act of 1981, Pub. L. No. 97-34, § 221(a), 95 Stat. 172, 241 (1981) (establishing original research credit at I.R.C. § 44F (1981)).

200. The credit is $20 \%$ of qualified research expenditures in excess of a base amount that is a 
is temporary and has been extended more than a dozen times since its enactment in 1981.

These three tax provisions, sections 41,174 , and 1235 , clearly reflect a policy decision to incentivize the development of patents and patent-like property. Trade secrets and know-how that have potential for patentability should fall within the scope of these incentives. Section 174 regulations define deductible research and experimental expenditures broadly to include all costs incident to product development or improvement, which includes "any pilot model, process, formula, invention, technique, patent, or similar property." 20 Section 1235 regulations provide that no patent or patent application need be currently in existence, suggesting that an inventor can receive capital gain treatment for patentable, or patent-like, property. ${ }^{202}$

\section{Tax Rules Applicable to Other Intellectual Property Development Activities}

The three tax incentives for patents and patent-like property do not apply to other forms of intellectual property, such as copyrights and trademarks. ${ }^{203}$ While costs of developing these types of intellectual property must generally be capitalized, ${ }^{204}$ several exceptions have been carved out.

One exception from the capitalization requirement can be found in section $263 \mathrm{~A}(\mathrm{~h})$. That special provision, enacted in 1988, permits certain freelance writers, photographers, and artists to deduct "qualified creative expenses" that would otherwise have to be capitalized. ${ }^{205}$ The stated purpose of the exception was not to promote freelance activities but rather to relieve writers, photographers, and artists from the burden of the capitalization rules, especially when their activities may not generate income for years. ${ }^{206}$

A second exception from capitalization pertains to advertising expenditures that result in trademark and copyright protections. As discussed earlier, such

"fixed-base percentage" of the taxpayer's average annual gross receipts for the four preceding tax years. For established firms, the fixed-base percentage is generally based on a ratio of the taxpayer's qualified research expenses to its gross receipts for years 1984 to 1988 , capped at $16 \%$. For start-up firms, the fixed-base percentage is set at 3\% during the firm's first five tax years with spending on qualified research and gross receipts. In no event shall the base amount be less than $50 \%$ of the qualified research expenses for the credit year.

201. Treas. Reg. $\S 1.174-2$ (a)(1)-(2) (as amended in 1994).

202. Treas. Reg. § 1.1235-2(a) (1957); see Gilson v. Comm'r, 48 T.C.M. (CCH) 922 (1984) (allowing patent tax treatment even though only two of eight designs were patented).

203. See Treas. Reg. § 1.174-2(a)(3) (1960) (prohibiting deduction of expenditures for "literary, historical, or similar projects"); S. REP. No. 83-1622, at 439-40 (1954), reprinted in 1954 U.S.C.C.A.N. 4621, 5082.

204. I.R.C. $\$ 263 \mathrm{~A}$ (2006) (requiring capitalization of expenditures in connection with copyrightable subject matter); Treas. Reg. $\S 1.263$ (a)-4(b) (2004) (requiring capitalization of costs of obtaining rights from a governmental agency, as well as costs of creating any "separate and distinct intangible asset").

205. I.R.C. $\S 263 \mathrm{~A}(\mathrm{~h})$, enacted as part of the Technical and Miscellaneous Revenue Act of 1988, Pub. L. No. 100-647, $\S 6026,102$ Stat. 3342, 3691-92 (1988). A qualified creative expense is defined as any expense "paid or incurred by an individual in the trade or business of. . . being a writer, photographer, or artist," which, except for the uniform capitalization rules of section 263A, would be otherwise deductible for the taxable year. I.R.C. $\S 263 \mathrm{~A}(\mathrm{~h})(2)(\mathrm{A})$.

206. See H.R. REP. No. 100-1104, at 145 (1988) (Conf. Rep.), reprinted in 1988 U.S.C.C.A.N. 5048, 5205. 
costs are currently deductible as general advertising even though such costs provide benefits of a long-term nature. ${ }^{207}$

A third exception from the capitalization requirement pertains to software development costs. Also discussed earlier, such costs are currently deductible regardless of the type of intellectual property protection on the software. ${ }^{208}$ It should be noted that although these exceptions permit certain taxpayers to deduct actual creation and development costs (e.g., costs of writing a book, costs of developing a package design, costs of developing software), taxpayers are required to capitalize fees paid to any government agency to obtain trademark and copyright protections on the developed product. ${ }^{20}$

\section{B. ELIMINATING LOOPHOLES AND REMOVING TAX INEQUITIES}

\section{Tax Rules Governing Copyright Sales}

On several occasions, Congress has enacted provisions to close loopholes or remove tax inequities that existed under general tax rules. In the earliest example, in 1950, Congress enacted section 1221(a)(3) of the Code to close a loophole with respect to capital gain treatment on certain copyright sales. ${ }^{210}$ Prior to the enactment of section 1221(a)(3), the tax treatment of a sale of a copyright depended on the professional status of the writer, author, or photographer. For example, if the author of a book was a professional writer, the sale of the copyright for the book resulted in ordinary income because inventory is not considered a "capital asset," a requirement for capital gain treatment. $^{211}$ If the author was an amateur, however, the book was considered a capital asset, and the sale resulted in capital gain. To remove the loophole and provide uniform ordinary income treatment for the sale of self-created property, Congress added section 1221(a)(3) to exclude from the capital asset definition a copyright, a literary, musical, or artistic composition, or similar property held by the creator. ${ }^{212}$ This exclusion created a level playing field for professional and amateur copyright creators alike. It was also consistent with the idea of taxing wages and salaries as ordinary income.

Ironically, the 1950 law, which was designed to treat all copyright creators

207. See supra notes $184-91$ and accompanying text.

208. See supra notes $182-83$ and accompanying text.

209. Treas. Reg. § 1.263(a)-4(b)(1)(ii), (d)(5), (l), Ex. 9 (requiring capitalization of costs of obtaining certain rights from a governmental agency).

210. See Revenue Act of 1950, Pub. L. No. 81-814, $§ 210,64$ Stat. 906, 933 (codified as amended in I.R.C. $\S 1221$ (a)(3) (2006)).

211. I.R.C. $\S 1221$ (a)(1) (excluding from the definition of capital asset inventory or property held by the taxpayer primarily for sale to customers in the ordinary course of his or her trade or business).

212. See S. REP. No. 81-2375 (1950), reprinted in 1950 U.S.C.C.A.N. 3053, 3097. The capital asset exclusion for self-created property does not apply to non-individual creators, such as corporations whose employees or independent contractors created the copyrights. See Rev. Rul. 55-706, 1955-2 C.B. 300, superseded by Rev. Rul. 62-141, 1962-2 C.B. 181 (applying inventory exclusion, but not copyright exclusion, suggesting that the copyright exclusion does not apply to works-for-hire creations); see also Desilu Prods., Inc. v. Comm'r, 24 T.C.M. (CCH) 1695 (1965) (same). 
the same, was later viewed by some-particularly members of the countrymusic industry - as quite harsh to songwriters. Because the average annual income of songwriters was quite low and often came in spurts, some thought the taxing of gains realized from song sales should differ from the taxing of compensation earned by wage earners. ${ }^{213}$ In response, in 2006, Congress amended the 1950 law, creating an exception for sales of musical compositions and copyrights in musical works. ${ }^{214}$ Under section 1221(b)(3), songwriters can elect to pay tax at capital gain rates rather than ordinary income rates on the sales of their copyrighted songs. ${ }^{215}$ Although this exception was pushed to remove perceived tax inequity facing songwriters, it could more accurately be viewed as a response to assiduous lobbying efforts by the music industry.

\section{Tax Rules for Trademark and Trade Name Expenditures}

To eliminate inequities facing small businesses that owned trademarks and trade names, Congress enacted section 177 in $1956 .{ }^{216}$ Before the enactment of section 177 , expenditures paid in connection with trademarks and trade names, such as legal fees, were not currently deductible ${ }^{217}$ and were not recoverable under early tax depreciation rules because trademarks and trade names have indeterminable useful lives. ${ }^{218}$ Certain large corporations, which had in-house legal staff handling trademark and trade name matters, were avoiding this result by deducting compensation with respect to these matters because of difficulties of identification. Smaller companies, which could not afford to maintain their own legal staff, had to pay outside counsel or consultants to perform functions related to trademarks and trade names and were required to capitalize such expenses. Section 177 was enacted as an attempt to eliminate the existing hardship and inequities facing small corporations. $^{219}$ It allowed a taxpayer to elect to depreciate over sixty months certain costs incurred in connection with the acquisition, protection, expansion,

213. See Brady Mullins, Music to Songwriters' Ears: Lower Taxes: Country Artists' Group Presses Lawmakers to Slash the Levy on Lyricists, WALL ST. J., Nov. 29, 2005, at A4 (quoting Bart Herbison, executive director of the Nashville Songwriters Association International). For criticism of this argument and government response, see James Edward Maule, I Sing a Song of Taxes, a Pocketful of Cries, MAUledAGAIN BLog (Nov. 30, 2005, 10:39 AM), $\mathrm{http} / /$ mauledagain.blogsport.com/2005_11_01_archive html.

214. See Tax Increase Prevention and Reconciliation Act of 2005, Pub. L. No. 109-222, § 204(a)(3), 120 Stat. 345 (2006), amended by Tax Relief and Health Care Act of 2006, Pub. L. No. 109-432, § 412, 120 Stat. 2922; see also H.R. REP. No. 109-455, at 94 (2006) (Conf. Rep.), reprinted in 2006 U.S.C.C.A.N. 234, 292.

215. Specifically, I.R.C. $\$ 1221$ (b)(3) (2006) provides that, at the election of a taxpayer, the section 1221(a)(1) and (a)(3) exclusions from capital asset status do "not apply to musical compositions or copyrights in musical works sold or exchanged by a taxpayer described in [section 1221(a)(3)]".

216. Act of June 29,1956 , Pub. L. No. 84-629, § 4(a), 70 Stat. 406 (1956).

217. For treatment of litigation costs incurred in trademark and trade name infringement cases, see supra notes 172-74 and accompanying text. For treatment of litigation costs incurred in defending cancellation of a trademark, see Georator Corp. v. United States, 485 F.2d 283, 287 (4th Cir. 1973) (holding that attorney's fees incurred in defending cancellation of a trademark were nondeductible capital expenditures).

218. See supra note 38 and accompanying text.

219. S. REP. No. 84-1941, at 3-4 (1956). 
registration, or defense of a trademark. ${ }^{220}$

Section 177 was repealed in $19866^{221}$ The tax rule for trademark and trade name expenditures was viewed as inappropriate for a number of reasons: the possibility that large companies were finding a way to deduct otherwise capital expenditures did not justify an amortization election for all; a five-year amortization only partially alleviated any unfairness; and there was no basis for a presumption that investment in trademarks and trade names produced social benefits that market forces might adequately reflect. ${ }^{222}$

\section{Tax Rules for Charitable Contributions of Intellectual Property}

In its most dramatic effort to alleviate unfairness and close a tax loophole, Congress amended on two occasions the charitable deduction rules for intellectual property donations. ${ }^{223}$ Since 1917 , the government has provided a financial incentive for taxpayers to transfer property to charities by giving taxpayers an immediate tax deduction for their donations. ${ }^{224}$ Historically, the amount of the taxpayer's charitable contribution deduction was the fair market value of the property contributed. ${ }^{225}$ By granting an immediate deduction equal to the fair market value of the donated property, the charitable deduction provided an important economic incentive for patentees, authors, and artists to donate their patents and creative works to further the work of charitable organizations. ${ }^{226}$ The deduction served as an important incentive for writers, artists, and photographers to make in-kind donations to museums, libraries, universities, and other charitable organizations. ${ }^{227}$ Similarly, it was a vital tool for the transfer of technology from research corporations to research universities and other nonprofit donees where the technologies could be exploited properly. ${ }^{228}$

220. I.R.C. $\S 177$ (repealed 1986).

221. Tax Reform Act of 1986, Pub. L. No. 99-514, § 241(a), 100 Stat. 2085, 2181 (1986).

222. S. REP. No. 99-313, at 256 (1986).

223. See American Jobs Creation Act of 2004, Pub. L. No. 108-357, § 882, 118 Stat. 1418 (2004).

224. See Revenue Act of 1917 , Pub. L. No. $65-50, \S 1201$ (2)(a), 40 Stat. 300, 330 (1917) (allowing charitable tax deduction for contributions by individuals); see also Revenue Act of 1935, Pub. L. No. 74-407, § 102(r), 49 Stat. 1014, 1016 (1935) (allowing charitable tax deduction for contributions by corporations). For the modern day statutory provision, see I.R.C. $\S 170$ (2006).

225. See Rev. Rul. 58-260, 1958-1 C.B. 126 ('The fair market value of an undivided present interest in a patent, which is contributed by the owner of the patent to an organization described in section 170 (c) ... constitutes an allowable deduction as a charitable contribution, to the extent provided in section 170 , in the taxable year in which such property is contributed."); see also Treas. Reg. $\S 1.170 \mathrm{~A}-1$ (c) (2010) ("If a charitable contribution is made in property other than money, the amount of the contribution is the fair market value of the property at the time of the contribution reduced as provided in section 170(e)(1) . .. ."); H.R. REP. No. 91-413, at 53 (1969), reprinted in 1969 U.S.C.C.A.N. 1645, 1699 (providing that taxpayer who contributed appreciated property to charity was allowed a deduction for fair market value of property).

226. See I.R.C. $\$ 170(a)(1)(2006)$

227. See id. $\S 170(\mathrm{c})(2)(\mathrm{b})$.

228. Large corporations with research and development facilities often develop patents that later become inconsistent with their missions or core technologies, that are inappropriate for licensing to third parties, or that have no value (for defensive purposes) in competitive markets. See Ron Layton \& Peter Bloch, IP Donations: A Policy Review 5 (2004). 
The government defined "fair market value" as "the price at which the property would change hands between a willing buyer and a willing seller, neither being under any compulsion to buy or sell and both having reasonable knowledge of relevant facts." 229 The government, however, never fully articulated or formalized a standard or approach for determining the fair market value of donated intellectual property. ${ }^{230}$ As a consequence, valuation conflicts between donors and the government increasingly occurred as intellectual property grew in value and the practice of intellectual property donations also grew.

In its first major attack on intellectual property donations, Congress took significant measures to curtail the availability of immediate tax benefits for contributions of copyrights by creators. ${ }^{232}$ Section $170(\mathrm{e})$, added by the Tax Reform Act of 1969, reduced the amount of the charitable deduction from fair market value to the creator's basis in the copyright. ${ }^{233}$ Because copyright creators typically have a zero basis, or very low basis, in their copyrighted works, the amendment effectively precluded artists, musicians, photographers, and other copyright creators from enjoying any tax benefit from their charitable donations. ${ }^{234}$

The 1969 amendment impacted only copyright creators. ${ }^{235}$ It had no effect on copyright purchasers who later donated their intellectual property. Similarly, the amendment had no effect on other forms of intellectual property, such as patents, trademarks, trade names, and computer software. ${ }^{236}$ This created questionable distinctions in the tax system. Art collectors and investors were entitled to deduct the fair market value of their tangible property donations, but artists were entitled to deduct only their basis in their donated self-created works. ${ }^{237}$ Likewise, patent developers were entitled to deduct the fair market value of their donated patents, but copyright creators were entitled to deduct only the basis in their donated copyrights. ${ }^{238}$ These distinctions remained in the Code for thirty-five years until Congress's second

229. Treas. Reg. $\S 1.170 \mathrm{~A}-1$ (c)(2) (2010)

230. I.R.C. $\S 170$ (c)(2)(b) (2006).

231. Sean Conley, Paint a New Picture: The Artist-Museum Partnership Act and the Opening of New Markets for Charitable Giving, 20 DePAUl J. ART, TECH. \& INTELL. Prop. L. 89, 93 (2009).

232. Tax Reform Act of 1969 , Pub. L. No. 91-172, § 201(a), 83 Stat. 487, 555 (1970)

233. Id.

234. An artist's basis in her copyrighted artwork, for instance, is the cost of the brushes, canvases, pencils, or paper to the extent not previously deducted.

235. See Staff of the Jont Comm. on Internal Revenue Taxation, 91st Cong., General Explanation of the TAx Reform ACt of 1969, at 171-72 (Comm. Print 1970).

236. Id.

237. As one notable artist stated: "If anyone else buys my painting for $\$ 2$, he can then give it to a museum and deduct $\$ 10,000$ from his taxes, if that is the market value of the piece. If I myself donate it, I get $\$ 2$ tax credit, because that is what the paint and the canvas cost." Burgess J.W. Raby \& William L. Raby, Artists, Tax Collectors, and Private Foundation Status, 103 TAX NOTES 195, 195 n.1 (2004) (quoting artist Ettore De Grazia, who gained notoriety after he burned over 100 of his oil paintings over frustration with tax treatment of successful artists).

238. See I.R.C. $\$ 170(\mathrm{e})(1)(\mathrm{b})(\mathrm{iii})(2006)$. 
major attack on intellectual property donations in $2004{ }^{239}$

As patents became increasingly valuable assets and patent donations flourished, the government became increasingly concerned over valuation abuses by patent donors, and courts were increasingly confronted with valuation disputes. ${ }^{240}$ In 2004 , in a drastic and hasty move, Congress amended the charitable deduction provision by eliminating the fair market value standard for contributions of most forms of intellectual property, reducing the initial amount a donor may deduct. ${ }^{241}$ As with the 1969 legislation impacting self-created copyrights, the 2004 legislation limited the initial charitable deduction of any type of intellectual property to the property's tax basis. ${ }^{242}$ Often the donor's tax basis in intellectual property is very small; in many cases, the donor's basis is zero because development costs are often deducted when incurred. ${ }^{243}$ To encourage charitable giving of intellectual property, Congress deemed it appropriate to grant donors of intellectual property future charitable deductions based on the income received by the donee charity. ${ }^{244}$ Specifically, the donor can take a deduction for up to ten years for gifts of royalty-producing intellectual property to public charities. ${ }^{245}$ The amount of the charitable deduction is a percentage of the royalty income earned by the donee. ${ }^{246}$ The percentage declines over time. ${ }^{247}$

\section{SIMPLIFYING RULES AND IMPROVING CLARITY OF TAX RESUlT}

In many instances, special tax rules were enacted to reduce procedural dissonance that occurred upon the application of general tax rules to intellectual property. ${ }^{248}$ As explained earlier, numerous disputes between taxpayers and the government arose over the proper tax treatment of intellectual property development and acquisition costs as well as over the

239. See American Jobs Creation Act of 2004, Pub. L. No. 108-357, § 1, 118 Stat. 1418.

240. In Notice 2004-7, the Service stated that "some taxpayers that transfer patents or other intellectual property to charitable organizations are claiming charitable contribution deductions in excess of the amounts to which they are entitled" and warned that "the Service intends to disallow improper charitable contribution deductions claimed by taxpayers in connection with the transfer of patents or other intellectual property to charitable organizations." I.R.S. Notice 2004-7, 20041 C.B. 310. A number of courts had also been addressing valuation disputes. See, e.g., Smith v. Comm'r, 41 T.C.M. (CCH) 1427 (1981), aff'd, 691 F.2d 508 (9th Cir. 1982) (concluding that the value of a donated patent was $\$ 3,500$, although patent donor claimed charitable deduction in excess of $\$ 200,000)$.

241. American Jobs Creation Act, $\S 1$. The 2004 legislation applies to most forms of intellectual property including patents, certain copyrights, trademarks, trade names, trade secrets and know-how, certain software, and similar intellectual property or applications or registrations of such property. H.R. REP. No. 108-548, at 360, 362 (2004).

242. See I.R.S. Notice $2004-7,2004-1$ C.B. 310.

243. See I.R.C. § 174(a) (2006), discussed supra notes 195, 201 and accompanying text.

244. I.R.C. $\S 170(\mathrm{~m})(3)$.

245. Id. $\S 170(\mathrm{~m})(5)$.

246. Id. $\S 170(\mathrm{~m})(7)$.

247. Id. $\S 170(\mathrm{~m})(1),(7)$. The deduction under section $170(\mathrm{~m})$ is subject to the percentage limits in section $170(\mathrm{~b})(1)(\mathrm{A})$ and is reduced by the amount of the deduction allowed in the year of the gift. Id. $\S 170(\mathrm{~m})(2),(10)(\mathrm{A})$.

248. See S. REP. No. 83-1622, at 112 (1954), reprinted in 1954 U.S.C.C.A.N. 4621, 4747; S. REP. No. 91-552, at 198-99 (1969), reprinted in 1969 U.S.C.C.A.N. 2027, 2243-44. 
proper tax treatment of intellectual property disposition proceeds. ${ }^{249}$ There also existed considerable diversity of opinion among the courts over how to apply general tax principles to increasingly valuable intellectual property assets. ${ }^{250}$ On several occasions, Congress enacted federal legislation to improve clarity of tax result. ${ }^{251}$

\section{Tax Rules for Patent Development and Assignments}

In the earliest example, Congress enacted in 1954 sections 174 and 1235 , which helped to eliminate uncertainties over the proper tax treatment of patent development costs and patent assignments. ${ }^{252}$ Section 174 allows taxpayers to elect to immediately deduct qualified research expenditures that would otherwise be capitalized. ${ }^{253}$ While the primary justification for the special deduction was to encourage new research and development activity and stimulate economic growth and technological development, ${ }^{254}$ another justification was to reduce uncertainties caused by applying the asset capitalization rules to research and development activities.

Section 1235 provides some bright-line rules for determining when a patent transfer will qualify for reduced capital gain rates as opposed to ordinary income tax rates. ${ }^{256}$ While it was intended to encourage research and development that potentially leads to patentable inventions, it was also an attempt to reduce uncertainty and minimize disputes over the application of general tax principles to patent transfers. ${ }^{257}$ When applicable, section 1235 provides statutory assurance that a patent transfer will not be deemed a license merely because of the existence of contingent payments. ${ }^{258}$ It eliminates uncertainty over whether a patent transferor is an amateur, who is eligible for

249. Gregory M. Beil, Internal Revemue Code Section 197: A Cure for the Controversy Over the Amortization of Acquired Intangible Assets, 49 U. MLAMI L. REv. 731, 734 (1995).

250. S. REP. No. 91-552, at 198.

251. See I.R.C. $\S \S 174(a), 1235(a)$.

252. Id.

253. See supra notes 195,201 and accompanying text.

254. See supra note 195.

255. See supra notes 16-29 and accompanying text. See David S. Hudson, The Tax Concept of Research or Experimentation, 45 TAX LAw. 85, 88-89 (1991) (explaining that another justification for section 174 is that the capitalization rule is difficult to applying to research and development costs); George Mundstock, Taxation of Business Intangible Capital, 135 U. PA. L. REV. 1179, 1258-59 (1987) (stating a reason for enacting section 174 was to reduce uncertainty caused by applying the asset-capitalization rules to research and development).

256. See supra notes $196-97$ and accompanying text.

257. See S. REP. No. 83-1622, at 422 (1954), reprinted in 1954 U.S.C.C.A.N. 4621, 5082. A stated policy goal underlying $\S 1235$ 's enactment is "to provide an incentive to inventors to contribute to the welfare of the Nation." Id.

258. See I.R.C. $\S 1235$ (a) (2006) (providing that section 1235 applies regardless of whether the payments received are payable periodically over a period generally coterminous with the transferee's use of the patent or are contingent on the productivity, use, or disposition of the property transferred); see also S. REP. No. 83-1622, at 422 (1954), reprinted in 1954 U.S.C.C.A.N. 4621,5082 (stating that section 1235 was intended "to give statutory assurance to certain patent holders that the sale of a patent (whether as an 'assignment' or 'exclusive license') shall not be deemed not to constitute a 'sale or exchange' for tax purposes solely on account of the mode of payment."). 
capital gain treatment under general tax principles, or a professional inventor, who is not eligible for capital gain treatment under general tax principles. ${ }^{259}$ And, it eliminates the need to ascertain the holding period of an invention for purposes of meeting the requisite one-year holding period under the general capital gain provisions. ${ }^{260}$ If the safe harbor provision is satisfied (there exists a transfer of "all substantial rights" by a "holder" to an unrelated party, as those terms are defined), then a patent transferor is assured capital gain treatment. $^{261}$ Determinations of what constitutes a sale under general sale or exchange principles and determinations of what constitutes a capital asset are therefore unnecessary.

\section{Tax Rules for Trademark and Trade Name Dispositions}

Another area of the law in desperate need of clarification concerned the proper tax consequences of trademark and trade name dispositions. As discussed earlier, there was considerable diversity of opinion among courts over what sorts of interests retained by transferors should preclude capital gain treatment, and there was uncertainty over the impact of contingent payments in trademark and trade name transfers. ${ }_{262}{ }_{263}$ Congress added section 1253 in 1969 to bring clarity to this area of the law. ${ }^{263}$

First, section 1253 mandates ordinary income treatment for all payments that are contingent on the productivity, use, or disposition of a trademark or trade name. ${ }^{264}$ Contingent amounts received or accrued for the transfer of a trademark or trade name constitute ordinary income regardless of whether the transfer is in substance a sale or a license. ${ }^{265}$ Second, section 1253 imposes ordinary income treatment on noncontingent payments (whether up-front or installment payments) received for the transfer of a trademark or trade name if the transferor retains any significant power, right, or continuing interest with

259. See H.R. ReP. No. 83-1337, at A280 (1954), reprinted in 1954 U.S.C.C.A.N. 4017, 4422; S. REP. No. 83-1622, at 112 (1954), reprinted in 1954 U.S.C.C.A.N. 4621, 4747 (stating that section 1235 can provide capital gains treatment to all inventors, whether amateur or professional, regardless how often they sell their patents).

260. See I.R.C. $\S 1222$ (3) (2006). The tax treatment of a capital gain depends generally on the property's holding period. See id. Under general characterization rules, only long-term capital gains are accorded preferential tax treatment. See id. A long-term capital gain requires a holding period of more than one year. See id. Under the special characterization provision of section 1235, however, the actual holding period becomes irrelevant. See id.

261. Id. $\S 1235$ (a)-(b), (d).

262. See supra notes $158-63$ and accompanying text.

263. Tax Reform Act of 1969, Pub. L. No. 91-172, § 516(c)(1), 83 Stat. 487, 647 (1969); see also S. REP. No. 91-552, reprinted in 1969 U.S.C.C.A.N. 2027, 2243; H. REP. No. 91-413, reprinted in 1969 U.S.C.C.A.N. 1645, 1815-16.

264. I.R.C. $\$ 1253$ (c) (2006).

265. A question left open by Congress is whether all payments received in a sale should be treated as ordinary income with no basis recovery or whether the transferor should be permitted to recover his or her basis. In other words, does section 1253 transform a transaction, which in form and substance is a sale, into a license? See James O. Tomerlin Trust v. Comm'r, 87 T.C. 876, 892 (1986) (holding characterization of payments under section 1253 was inconclusive in determining whether payments were royalties for purposes of the personal holding company tax because section 1253 does not determine whether a sale has occurred). 
respect to the subject matter of the mark or name. ${ }^{266}$ The Code sets forth six potentially significant powers, any one of which, if retained, would require ordinary income treatment. ${ }^{267}$ This list of retained powers is not exhaustive; rather, consideration is given to all the facts and circumstances existing at the time of a transfer to determine whether an unenumerated power constitutes a significant power. For example, the duration of the relevant restriction is important in determining whether the restriction is significant. ${ }^{268}$

While clarifying the tax consequences to transferors of trademarks and trade names, Congress also, in 1969, provided a new set of tax rules for transferees of such property. ${ }^{269}$ Section 1253 clarified that a transferee could deduct as a business expense contingent payments, i.e., payments contingent on the productivity, use, or disposition of the trademark or trade name transferred. ${ }^{270}$ In the case of a lump sum payment, section 1253 provided that the transferee could amortize the payment over the lesser of the term of the trademark agreement if the agreement had a limited term or ten years. ${ }^{271}$ In 1989, Congress amended section 1253. First, it provided that a transferee's contingent payments were deductible only if the contingent amounts were paid as part of a series of payments that were payable at least annually throughout the term of the transfer agreement, and the payments were substantially equal in amount or payable under a fixed formula. ${ }^{272}$ Second, it limited the ten-year amortization rule for lump sum amounts to transactions in which the lump sum amount paid for a trademark or trade name did not exceed $\$ 100,000$; it also provided a new twenty-five year amortization period for fixed sum amounts

266. I.R.C. $\S 1253$ (a) (2006)

267. Significant retained powers, rights, and interests include: the right to disapprove an assignment, the power to terminate the transfer at will; the right to prescribe standards of quality for the transferee using the trademark; the right to require the transferee to enter an exclusive sales agreement with the transferor; the right to require that the transferee purchase substantially all supplies and equipment from the transferor; and the right to payments contingent upon the productivity, use, or disposition of the trademark or trade name were such payments are a substantial element of the transfer agreement. Id. $\S 1253(\mathrm{~b})(2)(\mathrm{A})-(\mathrm{F}) ;$ see Consol. Foods Corp. v. United States, 569 F.2d 436, 438 n.1 (7th Cir. 1978); see also Stokely USA, Inc. v. Comm'r, 100 T.C. 439, 457 (1993); Jefferson-Pilot Corp. v. Comm'r, 98 T.C. 435, 447-48 (1992), aff'd, 995 F.2d 530 (4th Cir. 1993); Tele-Commc'ns, Inc. v. Comm'r, 95 T.C. 495, 515-16 (1990), aff'd, 12 F.3d 1005 (10th Cir. 1993).

268. See Stokely USA Inc., 100 T.C. at 455-57 (finding a five-year right to disapprove a transfer insignificant, but finding significant a twenty-year restriction preventing the transferee from using the trademark on certain products).

269. I.R.C. $\S 1253$ (c)-(d) (1970).

270. Id. $\S 1253$ (d)(1) ("Amounts paid or incurred during the taxable year on account of a transfer, sale, or other disposition of a franchise, trademark, or trade name which are contingent on the productivity, use, or disposition of the franchise, trademark, or trade name transferred shall be allowed as a deduction under section 162(a)."). Tax Reform Act of 1969, Pub. L. No. 91-172, $\S 516(\mathrm{c})(1), 83$ Stat. 487,647 (1969).

271. I.R.C. $\$ 1253$ (d)(2) (1969). Section 1253(d)(2) provided for amortization of the cost of a trademark or trade name if, pursuant to section $1253(\mathrm{a})$, the transfer of the trademark was not treated as a sale or exchange of a capital asset. Id. Section 1253(a) stated that a transfer was not treated as a sale or exchange of a capital asset if the transferor retained any significant power, right, or continuing interest with respect to the subject matter of the trademark or trade name. Id. $\S 1253(\mathrm{a})(1969)$.

272. Omnibus Budget Reconciliation Act of 1989, Pub. L. No. 101-239, § 7662(a), 103 Stat. $2106,2377$. 
exceeding $\$ 100,000{ }^{273}$ In 1993 , the ten-year and twenty-five-year amortization rules in section 1253 were eliminated with the enactment of section 197, which provided a fifteen-year amortization rule for capitalized trademark and trade name acquisition costs. ${ }^{274}$ As discussed below, the purpose of section 197 and the corresponding changes to section 1253 was to simplify the law and minimize disputes regarding the depreciation of intangibles. ${ }^{275}$

\section{Tax Rules for Depreciating Intellectual Property Acquisition Costs}

Without doubt, Congress's greatest effort at rule simplification occurred in 1993 when Congress attempted to simplify tax depreciation rules for intangible property. Under historic tax depreciation rules, the capitalized costs of acquiring intellectual property could be recovered only if the intellectual property had a limited useful life that could be determined with reasonable accuracy. ${ }^{276}$ As explained earlier, there were many problems with applying these traditional tax depreciation rules to intellectual property. ${ }^{277}$ To address these problems and simplify the tax treatment of intangibles, Congress enacted, in 1993 , section 197. ${ }^{278}$ Section 197 provides a single depreciation method (straight-line depreciation) and a single recovery period (fifteen years) for the capitalized costs of acquiring many forms of intellectual property. ${ }^{279}$ The fifteen-year recovery period was not based on any measure of actual usefulness of intangibles in a business but was chosen because it was the shortest period that would not have a negative revenue impact. ${ }^{280}$

Section 197 provides a list of intangible property that is subject to ratable,

273. Id. $\S 7662(\mathrm{~b})-(\mathrm{c})$.

274. Omnibus Budget Reconciliation Act of 1993, Pub. L. No. 103-66, § 13261(c), 107 Stat. 312,539 (Paragraph (1) of section 1253(d) remained the same allowing a current deduction for contingent serial payments. Paragraphs (2), (3), (4), and (5) of section 1253(d) were replaced with new paragraphs (2) and (3). New paragraph (2) provides that "[a]ny amount paid or incurred on account of a transfer, sale, or other disposition of a . . . trademark, or trade name to which paragraph (1) does not apply shall be ... chargeable to capital account.").

275. H.R. REP. No. 103-213, at 690 (Conf. Rep.), reprinted in 1993 U.S.C.C.A.N. 1088, 1379 .

276. See Treas. Reg. § 1.167(a)-3 (2010), discussed supra notes 35-39 and accompanying text. See Staff of Jont Comm. on Taxation, 103D Cong., Technical Explanation of the TAX Simplification ACT of 1993, at 1 (Comm. Print 1993) (explaining that Congress created section 197 to eliminate considerable confusion over the federal tax treatment of amortizable intangible assets).

277. See supra notes $40-52$ and accompanying text.

278. Revenue Reconciliation Act of 1993, Pub. L. No. 103-66, 107 Stat. 312, 416 (codified as amended at 26 U.S.C. $\$ 197(1993)$ ).

279. Specifically, section 197 provides a fifteen-year depreciation deduction for the capitalized costs of an "amortizable section 197 intangible," and prohibits any other depreciation or amortization deduction with respect to that property. I.R.C. $\S 197$ (a)-(b) (2006). Section 197 defines an "amortizable section 197 intangible" as any "section 197 intangible" acquired after August 10,1993, and held in connection with a trade or business or an activity conducted for profit. Id. $\S 197(\mathrm{c})(1)$. Section 197 provides a list of intangible assets that fall within the definition of "section 197 intangible" and are subject to fifteen-year amortization. Id. § 197(d). Section 197 also specifically excludes certain intangible assets. Id. $\S 197(\mathrm{e})$.

280. Beil, supra note 249 , at $733-34$. 
fifteen-year depreciation. ${ }^{281}$ Specifically mentioned is "any patent, copyright, formula, process, design, pattern, know-how, format, package design, computer software ... or interest in a film, sound recording, video tape, book, or other similar property, "282 as well as any trademark or trade name. ${ }^{283}$ Section 197 intangible property also includes goodwill, going concern value, customer lists, covenants not to compete, and a few other intangibles. ${ }^{284}$

Although the definition of section 197 intangibles appears broad enough to encompass nearly all forms of intellectual property, there are several important exceptions. Section 197 does not apply to off-the-shelf software. ${ }^{285}$ More importantly, though, section 197 does not apply to any interest in a patent, patent application, copyright, or computer software that is not acquired as part of a purchase of a trade or business. ${ }^{286}$ Trade secrets, know-how, trademarks, and trade names are not included within the exception for separately acquired assets. ${ }^{287}$ Thus, these forms of intellectual property are subject to fifteen-year amortization under section 197 regardless of whether they were acquired as part of a trade or business or separately. ${ }^{288}$

Interestingly, Congress has chosen different tax depreciation rules for intellectual property excluded from section 197's scope-separately acquired patents, separately acquired copyrights, separately acquired software, and offthe-shelf software. ${ }^{289}$

For patents and copyrights acquired outside the context of a business acquisition, tax depreciation rules applicable prior to 1993 generally continue to apply. ${ }^{290}$ Thus, the capitalized costs of separately acquired patents and copyrights are recovered under one of two approaches: (1) over their useful lives under the straight-line method or (2) as income is earned under the income forecast method. ${ }^{291}$ In 1997, Congress codified the income forecast method of depreciation in section $167(\mathrm{~g})$ of the Code, providing a maximum recovery period of eleven years for income forecast property. ${ }^{292}$ In 2004,

281. I.R.C. $\$ 197$ (d)

282. Id. $\S 197$ (d)(1)(c)(iii); Treas. Reg. $\S 1.197-2$ (b)(5) (2010).

283. I.R.C. $\S 197(d)(1)(F)$; Treas. Reg. $\$ 1.197-2$ (b)(10) (2010).

284. I.R.C. $\S 197(d)(1)$.

285. Id. $\S 197(\mathrm{e})(3)(\mathrm{A})$. This exception applies to software (whether acquired as part of a trade or business or otherwise) that is readily available for purchase by the general public, is subject to a non-exclusive license, and that has not been substantially modified. Id.

286. Id. § 197(e)(3)(A)(ii), (e)(4); Treas. Reg. § 1.197-2(c)(7) (2010).

287. Treas. Reg. § 1.167(a)-14(a) (2010).

288. I.R.C. $\S 197$ (a).

289. See Treas. Reg. § 1.167(a)-14(a)-(b) (2010); Jobs and Growth Tax Reconciliation Act of 2003, Pub. L. No. 108-27, 117 Stat. 752,757 (2003)

290. Treas. Reg. § 1.167(a)-14(a) (providing that "intangibles excluded from section 197 are amortizable only if they qualify as property subject to the allowance for depreciation under section $\left.167(\mathrm{a})^{\prime \prime}\right)$.

291. See supra notes $37-42$ and accompanying text.

292. I.R.C. $\S 167(\mathrm{~g})$; see also the Small Business Job Protection Act of 1996 , Pub. L. No. $104-188, \S 1604,110$ Stat. 1755,1836 . Forecasted total income includes all income the taxpayer reasonably believes will be earned during the eleven-year period beginning with the year the property is placed in service. $\S 167(\mathrm{~g})(1)(\mathrm{A}),(\mathrm{g})(5)(\mathrm{C})$. In the eleventh year, a taxpayer may deduct any unrecovered costs left in the property. $\S 167(\mathrm{~g})(1)(\mathrm{C})$. 
Congress amended section $167(\mathrm{~g})$, limiting the types of property for which the income forecast method may be used. ${ }^{293}$ In 2005 , Congress again amended section $167(\mathrm{~g})$ to provide a special rule for applicable musical property. ${ }^{294}$ Although now expired, the provision permitted a taxpayer to elect to ratably deduct the costs of acquiring any musical composition or any copyright with respect to musical composition property over a five-year period instead of using the income forecast method. ${ }^{2}$

For off-the-shelf software and software acquired outside the context of a business acquisition, Congress created new cost recovery rules. Under section 167(f), which was added to the Code in 1993 along with section 197, such software is to be depreciated over 36 months using the straight-line method. ${ }^{296}$ The justification for carving out a short three-year recovery period for readily available software and separately acquired software was that computer software differs significantly from other forms of intangibles in that its value is ascertainable and it has a measurable useful life. ${ }^{297}$ A lengthy fifteen-year amortization period would bear no resemblance to the actual useful life of software 298 and would exact a penalty on those U.S. companies extensively using computer software in their operations. ${ }^{299}$ In 2003, Congress added off-

293. I.R.C. $\$ 167(\mathrm{~g})(6)$, amended by American Jobs Creation Act of 2004 , Pub. L. No. $108-$ $357, \S 2,118$ Stat. 1418 . Eligible property is specifically limited to interests (including interests involving limited rights) in the following property: (1) motion picture films, video tapes, and sound recordings; (2) copyrights; (3) books; (4) patents; (5) theatrical productions; and (6) other property as designated in published guidance by the Service. $\$ 167(\mathrm{~g})(6)$. The income forecast method is appropriate for these types of property because they possess unique income earning characteristics. For instance, the income potential of a purchased film varies as a direct result of the film's popularity; its economic usefulness cannot be measured adequately by the property's physical condition or by the passage of time. See Guidance Cost Recovery Under the Income Forecast Method, 67 Fed. Reg. 38,025 (May 31, 2002) (to be codified at 26 C.F.R. pt. 1) (explaining why the income forecast method is appropriate for properties specified in section $167(\mathrm{~g}))$.

294. I.R.C. $\S 167(\mathrm{~g})(8)(\mathrm{A})$, as added by the Tax Increase Prevention and Reconciliation Act of 2005, Pub. L. No. 109-222, §207, 120 Stat. 345,350 .

295. An election may not be made for any tax year beginning after December 31, 2010. I.R.C. $\S 167(\mathrm{~g})(8)(\mathrm{E})$. The special five-year option applied to capitalized expenditures paid or incurred by music publishers, performers, producers, and recording companies who acquired any applicable musical property (as well as to capitalized expenditures paid or incurred by songwriters and composers who created any applicable musical property). Id. $\S 167(\mathrm{~g})(8)(\mathrm{A})$, (C).

296. Omnibus Budget Reconciliation Act of 1993, Pub. L. No. 103-66, § 13261, 107 Stat. 312, 538. See H.R. ReP. No. 103-213, at 680 (1993) (Conf. Rep.), reprinted in 1993 U.S.C.C.A.N. 1088, 1369. For purposes of section $167(\mathrm{f})$, computer software is defined as "any program designed to cause a computer to perform a desired function." I.R.C. $\S \S 167(\mathrm{f})(1)(\mathrm{B})$, 197(e)(3)(B). The term does not include "any data base or similar item unless the data base or item is in the public domain and is incidental to the operation of otherwise qualifying computer software." Id.

297. Tax Treatment of Intangible Assets: Hearing Before the Comm. on Finance, $103 \mathrm{~d}$ Cong. 148 (1992) (statement of the Coalition for Fair Treatment of Intangibles) [hereinafter Statement of Coalition].

298. Id. at 36 (statement of William P. Benac, Treasurer, Electronic Data Systems). For example, Microsoft's word processing program "Word," which was introduced in 1983, saw four new versions and three major upgrades in the ten years subsequent to release. Id. at 51.

299. The fifteen-year amortization period under section 197 would impede the ability of the United States information technologies to compete in world markets because it would effectively raise the cost of acquiring computer software by ten to fifteen percent. Id. at 36. Many of the 
the-shelf computer software to the list of tangible property eligible to be expensed immediately under section $179 .{ }^{300}$ As a result, the cost of purchasing off-the-shelf software can be immediately deducted rather than capitalized and amortized over three years. ${ }^{301}$

With these enactments, Congress dramatically changed the depreciation rules for acquired intellectual property. Congress provided an arbitrary fifteenyear recovery period for intellectual property acquired in the context of a business acquisition, regardless of the intellectual property's legal life. ${ }^{302}$ And it carved out a special three-year rule for certain computer software-off-theshelf software and separately acquired software. ${ }^{303}$ Although Congress left the law as it was for several other forms of intangible assets, permitting them to be recovered over their useful lives under the straight-line method or over a maximum of eleven years under the income forecast method (e.g., separately acquired patents and separately acquired copyrights), these legislative enactments reflect a bold attempt to provide a uniform predictable set of tax rules for depreciating costs of intellectual property. ${ }^{304}$

\section{THE CURRENT TAX CODE AND INTELLECTUAL PROPERTY: A HARMONIOUS EXISTENCE?}

The United States has witnessed profound technological changes from the Industrial Revolution period to the Digital Age. The Industrial Revolution arrived in the United States and gave birth to subsequent eras wherein electricity switched nights to days, ${ }^{305}$ machines replaced manual labor, ${ }^{306}$ telephones replaced face-to-face communications, ${ }^{307}$ and rails connected

competing computer software nations already had tax policies in place allowing for computer software to be amortized over either a three or five year period. Id. at 36-37. Ultimately, a fifteen year amortization period would discourage software investment and impair international competitiveness. Statement of Coalition, supra note 297, at 148.

300. Since 1981, the government has permitted business taxpayers to elect to deduct immediately the cost of purchasing section 179 property. Section 179 property is generally tangible, depreciable, personal property - as opposed to real property - that is acquired for use in the active conduct of a trade or business. I.R.C. $\$ 179(\mathrm{~d})(1)$. Off-the-shelf software was added to the list of qualifying property by the Jobs and Growth Tax Relief and Reconciliation Act of 2003. Pub. L. No. 108-27, 117 Stat. 752,757 (2003).

301. Only off-the-shelf software purchased in a tax year beginning after 2002 and before 2012 qualifies for the special deduction under section 179. I.R.C. $\S 179(\mathrm{~d})(1)(\mathrm{A})$.

302. Beil, supra note 249 , at $733-34$.

303. I.R.C. $\S 167(\mathrm{a})(1)(\mathrm{A}),(\mathrm{g})(1)(\mathrm{c}),(\mathrm{g})(5)(\mathrm{c})$.

304. See id. $\$ 167(\mathrm{~g})(1)(\mathrm{A})$.

305. Thomas Edison invented the phonograph and incandescent light bulb in 1877 and 1879, respectively. See The Inventions of Thomas Edison, ABouT.com, $\mathrm{http} / /$ inventors about.com/library/inventors/b/edison htm (last visited Oct. 18, 2010).

306. Elias Howe invented and patented the sewing machine in 1846, and Isaac Singer improved and marketed Howe's sewing machine in 1851. See Elias Howe was the inventor of the first American-patented sewing machine, ABOUT.COM, http://inventors about.com/od/hstartinventors/a/Elias Howe htm (last visited Nov. 6, 2010)

307. Alexander Graham Bell invented the telephone in 1876. See Alexander Graham BellBiography, АвоUт.сом, http://inventors.about.com/library/inventors/bitelephone2.htm (last visited Nov. 6, 2010). 
people, shortened distances, and shrank durations. ${ }^{308}$ The rapid changes continued in the Digital/Information Age when most analog machines and mechanical devices were replaced by better, faster, and more capable digital devices. ${ }^{309}$ Data and information in every field are now collected, stored, dissected, analyzed, combined, and accessed digitally. ${ }^{310}$ Telecommunication is wireless, replacing the slow and costly landline telephones and connecting people worldwide. ${ }^{3 \Gamma 1}$ The Internet and its profound impact alter the ways humans communicate, function, connect, work, educate, and entertain together. ${ }^{312}$

The biotech industry has blossomed and flourished rapidly in the last couple of decades. ${ }^{313}$ Genetic engineering feeds billions with revolutionary approaches to farming and affects global populations' quality of life. ${ }^{314}$ Gene

308. For an account of the rapid changes in the United States during the Industrial Age, see generally JulIE Husband \& Jim O'LOUGHLIN, DAII LIFE IN THE INDUSTRIAL UNITED STATES, 1870-1900, at back cover (Greenwood Press 2004) ("Daily life in the Industrial age was everchanging, unsettling, outright dangerous, and often thrilling. Electric power turned night into day, cities swelled with immigrants from the countryside and from Europe, and great factories belched smoke and beat unnatural rhythms while turning out consumer goods at an astonishing pace. Distance and time condensed as rail travel and telegraph lines tied the vast United States together as never before.").

309. See Mathew Goodman, Digital Age Ushers in Epic Cinema Changes, Sunday Times, July $30, \quad 2006, \quad$ at $11, \quad$ available $\mathrm{http} / /$ business.timesonline.co.uk/tol/business/industry_sectors/media/article1084105.ece. Goodman noted that:

Traditional analogue equipment is able only to project reels of film on to the big screen. But digital projectors open up a range of new possibilities. For instance, they allow exhibitors to provide video games or broadcast live events, such as football matches or pop concerts. They could even be used by companies for sales demonstrations or lectures.

They also allow cinemas to become more flexible with the films they show. A piece of celluloid for an analogue projector is heavy, unwieldy and expensive to produce. Digital films are much easier, like changing a cartridge on a video-games [sic] console, and a fraction of the cost to produce. For a chain such as Cineworld, which prides itself on screening films tailored to its local customer base, such as showing Bollywood movies in areas with large Indian populations, it will make life much easier.

310. See generally Xuan-Thao N. Nguyen, Collateralizing Privacy, 78 TuL. L. REv. 553 (2004) (discussing how data is collected, used, and abused).

311. See, e.g., Michael L. Best, The Wireless Revolution and Universal Access, in TRENDS IN TELECOMMUNICATIONS REFORM 2003, at 107 (John Alden ed., 2003), available at http://cyber.law harvard.edu/digitaldemocracy/best-wirelessrevolution-sept03.

312. See generally Nguyen \& Maine, supra note 39; Nicholas Carr, Is Google Making Us Stupid?, THE ATLANTIC, July-Aug. 2008, at 56, available at http://www.theatlantic.com/doc/200807/google (discussing the impact of Google search and the Net as the universal medium for instant information); Jeff Goldsmith, How Will The Internet Change Our Health System?, HeALth AFFAIRs, Jan.-Feb. 2000, at 148, available at http://healthaff highwire.org/cgi/reprint/19/1/148. Conferences on online teaching with focuses on challenges and opportunities are frequent where administrators and educators convene to share their expertise. See ONLINE TEACHING CONFERENCE 2010, http://onlineteaching conference.org/presentations html (last visited Oct. 18, 2010).

313. See Peter S. Goodman, In N.C., A Second Industrial Revolution, WAsH. Post, Sept. 3 , 2007, at A01, (reporting on how the biotechnology and technology industries have transformed North Carolina and the United States).

314. See, e.g., Bryan Bergeron \& Paul Chan, Biotech Industry: A Global, ECONOMIC, AND FINANCING OVERVIEW 22 (2004) (asserting that the biotech industry has 
research has led to new understanding of diseases and cures. ${ }^{315}$ Biotechnologies are unraveling the unknown in cancers. ${ }^{316}$ New drugs are invented to alter the cause of death. 317

In the last forty years, intellectual property assets have risen meteorically, ascending in scale in corporate value and importance. In the decades before the Digital Age, companies such as Boeing, AT\&T, GE, IBM, Texas Instruments, Microsoft, and Apple rose to domination with their products and services that were covered by patents, copyrights, trade secrets, and trademarks that changed the way of business and daily life. ${ }^{318}$ Many of these companies and their founders became household names, replacing Alexander Graham Bell, Thomas Edison, and John Singer. ${ }^{319}$

The Digital Age arrived and forced companies to change, adapt, or perish. Those that adapted and continued to innovate had a chance to survive. Others faded. One thing is certain: intellectual property continues to serve as an important asset to corporate competition and growth. For example, Texas Instruments and IBM changed their core businesses, moved away from manufacturing products, and embraced a licensing model that allowed them to capitalize on their strengths based on powerful patent portfolios. ${ }^{320}$ Apple

impacted the "quality of life on a global scale").

315. Research Breakthrough Targets Genetic Diseases, Medical News Today (Jan. 20, 2009), http://www medicalnewstoday.com/articles/136010.php (reporting on genetic research breakthroughs). For latest information in gene research, biology and medicine news and technology, see About Us, BIo-MEDICINE, http://www.bio-medicine.org/ (last visited Oct. 13, 2010) (online web portals devoted to biology and medicine, posting the breaking news about the latest discoveries and research projects in the fields).

316. See Gordon McVie, What Does the Biotech Revolution Mean?, The Guardian (Mar. 9, 2003, 9:34 AM), http:/www.guardian.co.uk/society/2003/mar/09/health.lifeandhealth1 (focusing on how the biotech revolution would impact cancer research and treatment).

317. For latest reports on new drug breakthroughs, see Pharmaceutical News and Articles, DRUGS.COM, http://www.drugs.com/news.html (last visited Oct. 13, 2010),

318. The GE trademark alone was valued at $\$ 43$ billion in 2001, and the IBM trademark was valued at $\$ 52$ billion. IBM leads all companies in seeking and obtaining the most patents issued by the United States Patent Office for its ever-expanding patent portfolio. See Brad Stone, Nickels, Dimes, Billions: Big Tech Companies are Raking in Big Bucks-A Little at a Time-By Charging for Use of Their Imovations, NewsweEK (Aug. 2, 2004), http://newsweek.com/2004/08/01/nickels-dimes-billions.html\#.

319. When Bill Gates, the founder of Microsoft, stepped down there was an outpour of articles about the event. See, e.g., It's Official: The Microsoft 2.0 Era has Begun, Microsoft 2.0 (June 29, 2008 6:22 PM), http://www microsoft2 net/2008/06/29/its-official-the-microsoft-20era-has-begun/ (listing links to articles about Bill Gates leaving Microsoft after 33 years from The Economist, ABC News, National Public Radio, Investor's Business Daily, Gizmodo, Wired, and Reuters). With respect to Steve Jobs of Apple, the public and investors' obsession with his health are routinely reported in the media. See, e.g., Henry Blodget, Time For Apple to Finally Level with Investors About Steve Jobs' Health and Future Role, BUSINESS INSDER (June 28, 2009, 10:06 AM), http://www.businessinsider.com/henry-blodget-time-for-apple-to-finally-level-withinvestors-about-steve-jobs-health-2009-6; Joe Nocera, Steve Jobs and Apple: Here We Go Again, N.Y. TIMES (June 23, 2009; $12: 56 \quad$ PM), http://executivesuite.blogs nytimes.com/2009/06/23/steve-jobs-and-apple-here-we-go-again/; Daniel Lyons, Why We Need Steve Jobs: Love Him or Hate Him, Apple Needs Its CEO Back. Now., NEwSwEEK (June 23, 2009), http://www newsweek.com/2009/06/22/why-we-need-stevejobs html.

320. See Xuan-Thao Nguyen \& Jeffrey A. Maine, Acquiring Imnovation, 57 AM. U. L. REv. $775,787-90$ (2008) (discussing the drastic change in business approach through aggressive patent licensing by TI and IBM); see also Stone, supra note 318 . Stone notes: 
changed its image of a desktop company to become an ultra-chic company with sleek products and accessories ranging from computing to telecommunications to entertainment. ${ }^{321}$ Anchoring Apple are the brand name, the trade secrets, the patents, the copyrights, and the software; they constitute the driving force for the creation, production, and distribution of Apple company products. ${ }^{322}$

In another example, Microsoft is no longer the global company with the omnipresence that it once had in the 1980s and early 1990s; Google has become the ubiquitous company globally. ${ }^{323}$ What does it own? Google is powerful because of its search engine technology, which competes fiercely against and eliminates others in the web search industry. ${ }^{324}$ Google's search

IBM set the standard for patent licensing in the early ' $90 \mathrm{~s}$. While Big Blue was in a steep decline, veteran employee and lawyer Marshall Phelps got the company to raise the fees it charged others for piggybacking on its ubiquitous technology. Phelps recalls that incoming CEO Lou Gerstner was skeptical of the program; at RJR Nabisco, he had been involved in a patent dispute with Procter \& Gamble over soft chocolate-chip cookies. Phelps changed Gerstner's mind by cracking open an IBM PC and showing him all the components that came from other companies. In other words: hardware companies were interdependent, and as the biggest fish in the sea, IBM should exploit that fact. A few years [] later[,] IBM was raking in $\$ 2$ billion

Id. a year of almost pure profit from licensing revenue.

321. Apple's products are often described as "cool" and "chic" by many. See John Delavan, Embrace Your Imer Geek, LEGAL MGMT., July-Aug. 2007, at 4, 4 ("[M]y partner and I embarked on a long-planned mission to upgrade our home-computing situation, replacing an antiquated Apple iMac (one of those cool-looking but gigantic blue-shell machines with a handle) with a spiffy new MacBook laptop."); John Delavan, Money Talks, LEGAL MGMt., Sept.-Oct. 2007 , at 4, 4 ("CEO Steve Jobs announced the release of a bunch of cool new products, including iPod nanos that play video and the iPod touch, a nifty device that does everything the popular iPhone does except make phone calls."); see also Lawrence M. Friedman, Browser Browsing, Oct. CHI. B. Ass'N REC., Oct. 2008, at 58, 58 ("My immediate reaction to the interface on Apple's Safari for Windows was, 'Cool, I am dabbling in Mac.' It feels a little like a [sic] being a college kid the first time you go into a jazz club.").

322. As intellectual property assets are important to its corporate dominance, Apple is aggressive in protecting its intellectual property rights. See Apple Computer, Inc. v. Doe 1, No. $1-04$-CV-032178, 2005 WL 578641, at ${ }^{*} 7-8$ (Cal. Super. Ct. Mar. 11, 2005) (ordering an ISP to disclose identities of Internet users accused of misappropriating Apple trade secrets), vacated, 44 Cal. Rptr. $3 \mathrm{~d} 72$ (Cal. Ct. App. 2006); see also Apple Computer, Inc. v. Microsoft Corp., 35 F.3d $1435,1446-47$ (9th Cir. 1994) (copyright infringement and other claims); Apple Inc. v. Psystar Corp., No. C 08-03251, 2009 WL 303046, at*1 (N.D. Cal. Feb. 6, 2009) (software and copyright infringement claims); Apple Computer, Inc. v. Podfitness, Inc., No. 06-5805, 2007 WL 1378020, at ${ }^{*} 1$ (N.D. Cal. May 10,2007) (trademark infringement and unfair competition claims); Victoria A. Cundiff, Reasonable Measures to Protect Trade Secrets in a Digital Environment, 49 IDEA 359, 404-05 (2009) (discussing how Apple sued to get the identity of the source for the trade secret disclosure).

323. See Rob Hof, Is Google Too Powerful?, Bus. WeEK (Apr. 9, 2007), $\mathrm{http} / / /$ www.businessweek.com/magazine/content/07 15/b4029001 htm? chan=gl (noting Google's global dominance in multiple industries and noting that Google's tactics and domination "might sound crazy given that we're talking about a nine-year-old company that wasn't even publicly traded until Aug. 19, 2004").

324. Id. (Google's search engine is 'the No. 1 gateway to the Net's vast commercial potential. With more data on what people are searching for, Google can serve up the most targeted and relevant advertisements alongside the results, drawing more clicks, more cash, more users-you get the idea."); see Miguel Helft, Google Makes a Case That It Isn't So Big, N.Y. TIMES, June 28, 2009 , at B1. ("Google handles roughly two-thirds of all Internet searches" and "owns the largest 
engine technology is proprietary and protected by trade secrets, software law, and patent law. ${ }^{325}$ Google has a vast database of information that is vital to its business. ${ }^{326}$ Google's vast content is not in a building; it is in a "cloud." 327 The name "Google" is not just the dictionary name "google" but a global brand with a value estimated at approximately $\$ 25.59$ billion, climbing from the rank of 20 th to 10 th global brand between 2007 and 2008 . $^{328}$

With these dynamic and profound technological changes, intellectual property has become a core corporate asset. ${ }^{329}$ Reflective of these

online video site, YouTube." Last year Google "sold nearly $\$ 22$ billion in advertising, more than any media company in the world.").

325. See Terms of Service, GooGLE, http://www.google.com/cse/docs/cse/tos html (last visited Oct. 22, 2010) (detailing Google's intellectual property and other rights and prohibiting users from violating Google's proprietary rights); Google's Opposition to the Government's Motion to Compel at 1, Gonzales v. Google, Inc., 234 F.R.D. 674 (N.D. Cal. 2006) (No. 5:06-mc$80006-\mathrm{JW}$ ), at 2006 WL 543697 (detailing Google's search engine technology and proprietary data protected under trade secret law).

326. Google's Opposition to the Government's Motion to Compel, supra note 325 ; see also Daisuke Wakabayashi, Microsoft Lawyer to Blast Google, RED HERRING (Mar. 5, 2007, 10:00 PM), http://www redherring.com/Home/21533 (reporting on Google's Book Search content and the allegations asserted by publishers against Google in copyright infringement suit); Janet Morrissey, Librarians Fighting Google's Book Deal, TIME (June 17, 2009), www.timecom/tim/printout/0,8816,1904495,00.html (reporting the Google Book content deal and the potential problems associated from the deal due to the vast size of the book content and Google's control).

327. Elizabeth Montalbano, Microsoft Criticizes Drafting of Secret "Cloud Manifesto CIO.COM (Mar. 26, 2009), http://www.cio.com/article/print486930/ (noting that Google is a big cloud proponent "with its Web-hosted products like the Apps collaboration suite and the App Engine development platform" while "Microsoft so far has neither been a thought nor a technology leader in cloud computing"); see also Stephen Baker, Google and the Wisdom of Clouds, Bus. WEEK (Dec. 13, 2007, 5:00 PM), http://www.businessweek.com/magazine/content/07_52/b4064048925836 htm. Baker notes:

What is Google's cloud? It's a network made of hundreds of thousands, or by some estimates 1 million, cheap servers, each not much more powerful than the PCs we have in our homes. It stores staggering amounts of data, including numerous copies of the World Wide Web. This makes search faster, helping ferret out answers to billions of queries in a fraction of a second. Unlike many traditional supercomputers, Google's system never ages. When its individual pieces die, usually after about three years, engineers pluck them out and replace them with new, faster boxes. This means the cloud regenerates as it grows, almost like a living thing. A move towards clouds signals a fundamental shift in how we handle information. At the most basic level, it's the computing equivalent of the evolution in electricity a century ago when farms and businesses shut down their own Baker, supra. generators and bought power instead from efficient industrial utilities.

328. See Best Global Brands 2008, Bus. WeEK, http://www.businessweek.com/interactive reports/global brand $2008 \mathrm{html}$ (last visited Feb. 17, 2011) [hereinafter Global Brands] (reporting on Google as a global brand name).

329. In the biotech industry, for example, the patentable subject matter of a man-made organism marked the beginning and growth of intellectual property assets and the biotech industry itself. See Intellectual Property, BIOMELBOURNe NETwORK, http://www.bio melbourne.org/content_pages/display/89 (last visited Oct. 16, 2010) ("The biotechnology industry as we know it did not exist prior to the landmark Supreme Court decision of Diamond v. Chakrabarty of 1980 . . . The patent system fosters the development of new biotechnology products and discoveries, new uses for old products and employment opportunities for [millions of Americans]. Nowhere is this more apparent than in the biotechnology arena. Patents add value to laboratory discoveries, providing incentives for private sector investment 
technological advancements and the rise of intellectual property as valuable assets is the growth of intellectual property law in the United States. ${ }^{330}$ Empowered by Article I, Section 8, of the Constitution, ${ }^{331}$ Congress passed the original patent and copyright statutes in April 1790 in the first congressional session. $^{332}$ As a result of subsequent case law development and statutory amendments through the years, patent, copyright, trademark, and trade secret laws are now well-developed in the United States. ${ }^{33}$

While the body of intellectual property laws developed rapidly beginning at the inception of the nation, income tax laws governing intellectual property were slow to evolve. ${ }^{334}$ Indeed, until the mid-twentieth century, the resolution of tax issues regarding intellectual property involved the use of existing, traditional principles of taxation equally applicable to tangible property. Specific tax rules governing intellectual property transactions developed

into biotechnology development of new medicines and diagnostics for treatment and monitoring of intractable diseases, and agricultural and environmental products, to meet global needs."). Intellectual property as core corporate assets can be seen through a brief review of brand names across the globe today and the billions of dollars each brand commands and the goods with which each brand is associated: Coca-Cola for beverages (valued at $\$ 70.45$ billion); IBM for computer services (valued at $\$ 64.73$ billion); GE for a wide range of industries from household appliances and heavy equipment to financing (valued at $\$ 42.81$ billion). See Global Brands, supra note 328.

330. See Alan Greenspan, Chairman, Fed. Reserve, Remarks at the Stanford Institute for Economic Policy Research Economic Summit (Feb. 27, 2004) (transcript available at http://www federalreserve.gov/boarddocs/speeches/2004/200402272/) ("[I]n recent decades, as the economic product of the United States has become so predominantly conceptual, [so] have issues related to the protection of intellectual property rights come to be seen as significant . . ."); Merrill Matthews, Jr. \& Tom Giovanetti, Why Intellectual Property Is Important, IDEAs (Inst. for Policy Innovation, Lewisville, Tex), July 8, 2002, at 1, available at http://www.ipi.org/IPI\%5CIPIPublications.nsf/PublicationLookupFullTextPDF/94061686270E14 F286256C3800514943/\$File/II-CaseForIP-2.pdf?OpenElement (stating that the United States has become the powerhouse of intellectual property as the economy has shifted from an industrial- to an information-based economy and a new creative class of workforce has replaced other groups of workers).

331. The Constitution of the United States provides: "The Congress shall have Power ... To promote the Progress of Science and useful Arts, by securing for limited Times to Authors and Inventors the exclusive Right to their respective Writings and Discoveries; ... ."U.S. ConST. art. I, $\S 8$, cl. 8.

332. Patent Act of 1790 , ch. 7, 1 Stat. 109, 110 (repealed 1793).

333. The patent statutes went through major revisions in 1952. See Diamond v. Diehr, 450 U.S. 175, 182 (1981) (noting the re-codification of patent statutes in 1952 and what Congress revised in that year); Graham v. John Deere Co. of Kan. City, 383 U.S. 1, 6-17 (1966) (discussing the Patent Act of 1952, noting the history of patent law in the early days when Thomas Jefferson was the Commissioner of the Patent Office, and the evolution of patent law, particularly on issues such as non-obviousness). Copyright law witnessed two major revisions: the Copyright Act of 1909 and the Copyright Act of 1976. See Copyright Act of 1909, Pub. L. No. 60-849, $§ 5,35$ Stat. 1075, 1076-77; Copyright Act of 1976, Pub. L. No. 94-553, $\S 102,90$ Stat. 2541, 2598 (codified at 17 U.S.C. $\$ 101$ (2009)); see also Lotus Dev. Corp. v. Paperback Software Int'1, 740 F. Supp. 37, 47-49 (D. Mass. 1990) (discussing changes and legislative history of copyright statutes). With respect to trademark law, a substantial revision occurred in 1946 with the passage of the Lanham Act on trademarks and unfair competition. See Beverly W. Pattishall et al., Trademarks and Unfair Competition 1-3 (1994) (tracking the development of trademark law through history up to the codification of the common law in the Lanham Act). The model trade secret law or the Uniform Trade Secrets Act was promulgated in 1979. See David S. Almeling, Four Reasons to Enact a Federal Trade Secrets Act, 19 Fordham Intell. Prop. Media \& ENT. L.J. 769, 772 (2009) (providing a history of trade secret law).

334. See supra Part IV. 
slowly and separately from the body of law governing intellectual property rights. ${ }^{335}$ These tax rules were designed primarily to resolve the procedural dissonance that occurred when general principles of taxation were used to resolve early intellectual property tax disputes. ${ }^{336}$ Much of that dissonance in the intersection of intellectual property and taxation has been detected and addressed. But the ad hoc development of special tax rules created primarily with tax goals in mind resulted in a tax system that does not ideally support the intellectual property system and modern trends, such as the current business practice of integration and bundling of different types of intellectual property.

\section{A. SUPPORTING INTELLECTUAL PROPERTY's INNOVATION GOALS}

The policy goals of intellectual property law often emphasize two main principles: innovation and efficiency. Patent and copyright laws, in general, motivate innovation and creative activities of inventors and authors and induce the "release to the public of the products of [their] creative genius." 337 Innovation is the cornerstone anchoring the growth and advancement of the United States. ${ }^{338}$ Trade secret protection embodies the policy goal of innovation in addition to achieving efficiency through reduction of business misconduct relating to trade secret misappropriation. ${ }^{339}$ Trademark law centers on the facilitation of efficiency in the marketplace for both consumers

335. See id.

336. See id.

337. Sony Corp. of America v. Universal City Studios, 464 U.S. 417, 429 (1984) (Copyright monopoly privileges "are neither unlimited nor primarily designed to provide a special private benefit. Rather, the limited grant is a means by which an important public purpose may be achieved. It is intended to motivate the creative activity of authors and inventors by the provision of a special reward."); United States v. Paramount Pictures, Inc., 334 U.S. 131, 158 (1948) ("The copyright law, like the patent statutes, makes reward to the owner a secondary consideration. . . It is said that reward to the author or artist serves to induce release to the public of the products of his creative genius."); see also Stephen Breyer, The Uneasy Case for Copyright: A Study of Copyright in Books, Photocopies, and Computer Programs, 84 HARV. L. REV. 281, 288-89 (1970) (examining the "property" right in copyrights and how the reward of "property" is "often created for reasons of efficiency").

338. See United States v. Line Materials Co., 333 U.S. 287, 332 (1948) ("As interpreter of the Congressional Acts that have expressed the patent policy of this nation since its beginning, this Court is entrusted with the protection of that policy against intrusions upon it. The crucial importance of the development of inventions and discoveries is not limited to this nation. As the population of the world has increased, its geographical frontiers have shrunk. However, the frontiers of science have expanded until civilization now depends largely upon discoveries on those frontiers to meet the infinite needs of the future. The United States, thus far, has taken a leading part in making those discoveries and in putting them to use.").

339. The Supreme Court has long recognized that with respect to innovations not eligible for patent protection: "Trade secret law will encourage invention in areas where patent law does not reach, and will prompt the independent innovator to proceed with the discovery and exploitation of his invention. Competition is fostered and the public is not deprived of the use of valuable, if not quite patentable, invention." Kewanee Oil Co. v. Bicron Corp., 416 U.S. 470, 485 (1974); see also RESTATEMENT (THIRD) OF UNFAIR COMPETTTION $§ 39 \mathrm{cmt}$ a (1995) ("[T]he protection of trade secrets has been justified as a means to encourage investment in research by providing an opportunity to capture the returns from successful innovations."); Katarzyna A. Czapracka, Antitrust and Trade Secrets: The U.S. and the EU Approach, 24 SANTA ClaRA COMPUTER \& High TeCH. L.J. 207, 212 (2008) ("Consequently, trade secret protection involves the same fundamental policy choices between favoring innovation and favoring competition as laws protecting other forms of IP."). 
and producers of trademarked products or services. ${ }^{340}$

The current tax regime governing intellectual property does not ideally support desirable intellectual property incentives and efficiencies. Several current tax rules reflect a policy decision to incentivize developments of patents and patent-like property. ${ }^{341}$ But these tax benefits are circumscribed in ways that undermine their utility. For example, the section 174 deduction for research and development expenditures applies to those inventors who use or intend to use their research results in a trade or business. ${ }^{342}$ The deduction arguably does not apply to an inventor who merely intends to license the results of her inventive activities for taxable income, although a few courts have found a trade or business of inventing and thus permitted current deductions. ${ }^{343}$

This requirement fails to recognize that, in today's innovation marketplace, very few individual inventors, startup companies, and young research entities develop their innovations into end products or services for commercial exploitation in a trade or business, but rather intend to sell or license their innovations to larger companies looking to acquire innovations to supplement their own research or build promising intellectual property portfolios. ${ }^{344}$

Like the section 174 deduction (enacted in 1954), the section 41 research credit (enacted in 1981) was designed to encourage additional research and development. ${ }^{345}$ As structured, however, the credit fails to achieve optimal technology outcomes. First, the credit's reformulation over the years has limited the types of research for which the credit is available. ${ }^{346}$ Second, the incremental nature of the credit means many businesses cannot make use of any of the credit, placing U.S. businesses at a competitive disadvantage as compared to international firms entitled to greater tax incentives in their countries for research spending. ${ }^{347}$ Third, the temporary nature of the credit

340. See Int'1 Bancorp, LLC v. Société des Bains de Mer et du Cercle Des Étrangers à Monaco, 329 F.3d 359, 381 (4th Cir. 2003) (stating that "the very real interest that our trademark laws have in minimizing consumer confusion" is to ensure "that our economy may enjoy the greatest possible of efficiencies"); William M. Landes \& Richard A. Posner, The Economics of Trademark Law, 78 TRADEMARK REP. 267, 267 (1988) ("The overall conclusion is that trademark law . . . can best be explained on the hypothesis that the law is trying to promote economic efficiency"); see also Berner Int'1 Corp. v. Mars Sales Co., 987 F.2d 975, 982 (3rd Cir. 1993) (commenting that "[t]rademark protection is desirable because of the efficiencies and incentives produced by symbolic affiliation of producer and quality product").

341. See I.R.C. $\S 41$ (2006) (providing a credit for certain research and development expenditures); $i d$. $\S 174$ (providing a deduction for certain research and development expenditures); $i d$. $\S 1235$ (providing preferential capital gain treatment for certain patent transfers). For a discussion of these tax incentives, see supra notes 194-202 and accompanying text.

342. See Nguyen \& Maine, supra note 2, at 28-29.

343. See id.

344. See id. at 29.

345. See supra notes $199-200$ and accompanying text.

346. Not all expenditures that qualify for the research deduction under section 174 qualify for the research credit under section 41 due to special regulatory requirements and exceptions.

347. The credit applies only to qualified research expenditures in excess of a base amount that 
makes it difficult for firms to plan research activities.

The current tax incentives for patents and patent-like property do not apply to other forms of valuable intellectual property, such as copyrightable property and trademarks. ${ }^{348}$ As a general rule, copyright and trademark development costs must be capitalized. ${ }^{349}$ Limited exceptions have been carved out but arguably do not go far enough to achieve optimal copyright and trademark goals. 350

With respect to copyright activities, a special exception in the Code permits freelance writers, photographers, and authors to deduct "qualified creative expenses" that would otherwise have to be capitalized. ${ }^{351}$ But the exception is overly restrictive. First, the exception is not so broad as to include all individuals engaged in any creative activity. Rather it is limited to only certain individuals-writers, photographers, and artists - as those terms are defined in the Code. $^{352}$ Tax benefits for patent inventors are not so restrictive; both individual and corporate inventors are eligible to deduct costs of developing or improving a product, which is broadly defined. ${ }^{353}$ Second, the exception for freelance writers, photographers, and authors is limited only to individuals whose activities rise to the level of a trade or business within the meaning of the Code. ${ }^{354}$ For example, an author may currently deduct the costs of writing a book but only if the author has already established himself in the trade or business of writing. This is not a requirement for patent inventors; they only need to show that they have the intent and capability to enter a business with the resulting technology. ${ }^{355}$ Further, although an author may deduct the costs

is a "fixed-base percentage" of the taxpayer's average annual gross receipts for the four preceding tax years. I.R.C. $\S 41(\mathrm{a})$, (c)(1). For established firms, the fixed-base percentage is generally based on a ratio of the taxpayer's qualified research expenses to its gross receipts for years 1984 to 1988 , capped at $16 \%$. Id. $\S 41$ (c)(3)(A). Calculating today's credit based on research spending relative to receipts in the years 1984-1988 does not reflect the realities of today's economic and technological world and could penalize a company that had high research spending levels during the 1984-1988 base period.

348. See, e.g., id. § 1235 .

349. Id. $\S \S 263,263 \mathrm{~A}$; Treas. Reg. $\S 1.263-4$ (2006).

350. See, e.g., I.R.C. $\S 263$ A(h).

351. See supra notes $205-06$ and accompanying text.

352. A "writer" is defined as an individual whose personal efforts create, or may be expected to create, a literary manuscript, musical composition, or dance score. I.R.C. $\S 263 \mathrm{~A}(\mathrm{~h})(3)(\mathrm{A})$. A "photographer" is defined as an individual whose personal efforts create, or are expected to create, a photograph, a photographic negative, or transparency. Id. $\$ 263 \mathrm{~A}(\mathrm{~h})(3)(\mathrm{B})$. An "artist" is an individual whose personal efforts create, or are expected to create, a picture, painting, sculpture, statue, etching, drawing, cartoon, graphic design, or original print edition. Id. $\S$ $263 \mathrm{~A}(\mathrm{~h})(3)(\mathrm{C})$.

353. Treas. Reg. $\S 1.174-2(a)$.

354. I.R.C. $\S 263 \mathrm{~A}(\mathrm{~h})(2)(\mathrm{A})$.

355. For research and development costs to be deductible under section 174 , they must be incurred "in connection with" the taxpayer's trade or business. Id. § 174. Prior to 1974, the Service and the courts took the position that in order to qualify for section 174 treatment, a taxpayer must have already engaged in a trade or business. Snow v. Comm'r, 482 F.2d 1029, 1031-32 (6th Cir. 1973), rev'd, 416 U.S. 500 (1974). However, the Supreme Court rejected this narrow approach and held that pre-operational research or experimental expenditures could qualify for the section 174 deduction. 416 U.S. 500. Although a taxpayer need not be currently conducting a business, the taxpayer must, however, demonstrate a realistic prospect of entering into a trade or business that will exploit the technology under development. See, e.g., Kantor v. 
of writing a book, the author cannot immediately deduct the attorney's fees or fees paid to any government agency to obtain copyright protections on the developed product. ${ }^{356}$ Again, these rules for attorney's and government fees do not apply to patent inventors; the tax law is very clear that all costs incident to the development of a patent are deductible, including attorney's fees in the prosecution of a patent application. ${ }^{357}$

Tax rules with respect to trademarks are quite unfavorable as compared to tax rules governing patents and arguably are in disharmony with trademark goals in general. ${ }^{358}$ Although the advertising costs of building up the goodwill value in trademarks are currently deductible even though such costs provide benefits of a long-term nature, most other trademark costs are not and must be capitalized. ${ }^{359}$ For example, the fees paid to a government agency to obtain trademark protections must be capitalized. ${ }^{360}$ In addition, legal fees incurred in trademark infringement actions generally must be capitalized. ${ }^{36}$

\section{B. SUPPORTING INTELLECTUAL PROPERTY CHANGES}

Special tax rules applicable to intellectual property reference and define specific types of intellectual property. ${ }^{362}$ For example, section 1235 of the Code applies only to "patents" as defined in the Treasury Regulations under section $1235,{ }^{363}$ section 1253 applies to "trademarks" and "trade names," as defined for tax purposes, ${ }^{364}$ and section 197 applies to an enumerated list of intangible intellectual property assets $s_{2}$ each of which is defined for tax purposes in the Treasury Regulations. ${ }^{365}$

One problem with this asset-specific approach is that the resulting tax regime governing intellectual property is not equipped to deal with emerging intangible intellectual property rights. For example, specific tax rules do not exist for domain names, valuable assets that emerged with the arrival of global electronic commerce transactions on the internet. ${ }^{366}$ Are domain names mere

Comm'r, 998 F.2d 1514, 1518 (9th Cir. 1993). In making this determination, the taxpayer must demonstrate both an objective intent to enter into the trade or business or the capability to do so. Id.

356. See supra notes 203-04 and accompanying text.

357. Treas. Reg. § 1.174-2(a)(1).

358. Id. $\S 1.197-2(\mathrm{a})(1),(\mathrm{b})(10),(\mathrm{c})(7)$.

359. Id. $\S 1.197-2(\mathrm{a})(1),(\mathrm{b})(10),(\mathrm{c})(7),(\mathrm{k})$.

360. See supra note 204 and accompanying text.

361. See supra notes $172-74$ and accompanying text.

362. See, e.g., Treas. Reg. $\S 1.1235-2$ (a) (as amended in 1980).

363. Id.

364. These terms were broadly defined in regulations that were proposed in 1971 but eventually withdrawn due to a sunset provision. Prop. Treas. Reg. $\S 1.1253-1,-3,36$ Fed. Reg. 13,148 (July 15, 1971), withdrawn by 58 Fed. Reg. 25,587 (Apr. 27, 1993). The term "trademark" for purposes of section 1253 was defined as "any word, name, symbol, or device, or any combination thereof, adopted and used by a manufacturer or merchant to identify his goods and distinguish them from those manufactured or sold by others." Id. $\S 1.1253-2(\mathrm{~b}), 36$ Fed. Reg. 13,151 (citing 15 U.S.C. $\S 1127(2000)$ ).

365. Treas. Reg. $\S 1.197-2$ (b).

366. See Geneviève Bergeron \& Réa Hawi, Dot-Ca Domain Name Dispute Resolution: Where Do We Stand Five Years after Implementation of the CIRA Policy, 21 INTELL. PROP. J. 
variations of traditional forms of intellectual property, to which the existing tax regime can be applied? It could be argued that domain names that function as "source identifiers should be treated under the current tax regime applicable to trademarks" but that generic domain names are not dealt with by the existing tax regime. ${ }^{367}$ This is troublesome in light of the valuable nature of generic domain names. Generic domain names are easy to remember-a generic or descriptive URL of a website. ${ }^{368}$ The names specify or describe the products or services offered at the website. ${ }^{369}$ For example, www.loans.com is a URL for the online lending and banking services; it was purchased by Bank of America for $\$ 3$ million. ${ }^{370}$ Such names are generally not protected under trademark laws because they are generic. ${ }^{371}$ Providing these names protection would render everyone else speechless and perpetuate anti-competiveness. ${ }^{372}$ Though there is no trademark protection for these generic names, they are valuable as domain names or URLs for a website. ${ }^{373}$ Indeed, in the early ecommerce era, internet companies paid millions of dollars for these generic names. ${ }^{374}$ Amazingly, the intellectual property tax regime does not specifically address these valuable assets.

Another problem with the intellectual property tax regime's asset-specific approach is that it is not equipped to tackle the increasing integration and

199, 200 (2008) ("Domain names, which are a true creation of the modern world of Internet, made their appearance in the commercial sector in 1993.").

367. See Nguyen \& Maine, supra note 39 , at 4.

368. See, e.g., Xuan-Thao N. Nguyen, Shifting the Paradigm in e-Commerce: Move Over Inherently Distinctive Trademarks-The e-Brand, i-Brand and Generic Domain Names Ascending to Power?, 50 AM. U. L. REV. 937, 965-66 (2001).

369. Sallen v. Corinthians Licenciamentos LTDA, 273 F.3d 14, 19 (1st Cir. 2001) (commenting that domain names are often company names and names of products and services).

370. Daniel Joelson, Banks Square Off Over Internet Domain Names, BANK TECH. NEws (Nov. 22, 2000), available at http://www.americanbanker.com/btn_issues/13_11/-137906-1 html (reporting that "loans.com" attracts daily visitors even though it does not have an active website).

371. See generally Nguyen \& Maine, supra note 39, at 48-55 (discussing how trademark law does not protect generic domain names). See also H. Marvin Ginn Corp. v. Int'l Ass'n of Fire Chiefs, Inc., 782 F.2d 987, 989 (Fed. Cir. 1986) (reiterating the basic trademark principle that generic terms do not receive trademark protections in any circumstance). The addition of .com to a generic term does not make the term registrable as a trademark. See In re Hotels.com, L.P., No. 76414272,2006 WL 2850864 , at * 12 (T.T.A.B. 2006) (Hotels.com is generic and therefore a composite word/design mark not registrable unless entire term is disclaimed) (not precedent).

372. See generally Nguyen, supra note 368, at 965-66 (commenting on whether generic domain names should be entitled to protection under existing law).

373. See Susan Barbieri Montgomery, The New Uniform Commercial Code: Security Interests in Intellectual Property, SM088 A.L.I.-A.B.A. ConTINUING LEGAL Educ. 373 (2007) (asserting that "not all domain names are marks and some of the most valuable domain names incorporate generic or descriptive terms not eligible for trademark protection, such as (www.sex.com)"); see also Ale House Mgmt., Inc. v. Raleigh Ale House, Inc., 205 F.3d 137, 140 (4th Cir. 2000) (holding genericness as a dispositive question to trademark protectability); Yellow Cab Co. of Charlottesville v. Rocha, No. CIV. A. 3:00CV00013, 2000 WL 1130621, at *8 (W.D. Va. July 5,2000 ).

374. Domain Name Prices Rise Again, Investor's Bus. DaIly, Dec. 29, 2003, at A02 (reporting that domain name prices are on the rise again as evident by the purchase of "men.com" for $\$ 1.3$ million by a group of entertainment executives from Rick Schwartz); S.A. Mathieson, It's All in the Name: Can You Still Find a Good Domain Name for Your Business?, ThE GUARDIAN, Oct. 30, the2003, at 19 (reporting the sale of the domain name "business.com" for $\$ 7.5$ million and “if.com" for $\$ 1$ million). 
bundling of intellectual property in business practice. Today, many different types of intellectual property are often bundled, as many forms of intellectual property protection are available for a particular product or service. ${ }^{375}{ }_{376}$ For example, Coca-Cola is protected by both trade secret and trademark laws. ${ }^{376}$

Software is a classic example of the "bundling" of rights in today's economy. For instance, Microsoft Windows is a set of complex software programs and is covered by many copyrights. ${ }^{377}$ Each time a new version of the software is created, there is a potential new copyright. ${ }^{378}$ Additionally, certain functions for Windows software programs are covered by patents. ${ }^{379}$ Moreover, there is proprietary information and know-how in Windows protected by trade secret law. ${ }^{380}$ The name "Windows" is a known trademark, identifies the products widely installed in most computers, and is used by millions. ${ }^{381}$ The four curving, colorful panels of the Windows logo are also entitled to protection under trademark law. ${ }^{382}$

Likewise, in the biotech or biopharma industry, drug companies rely on patents $^{383}$ and trade secrets for the protection of their research and development of certain drugs. ${ }^{384}$ The drug companies advertise the drugs, and

375. Additionally, companies often bundle different types of intellectual property assets when they license in or out for the daily business operation. See generally Nguyen, supra note 109, at 1309-10 (observing the bundling of trademarks and other intellectual property assets in licensing practices); Gideon Parchomovsky \& Peter Siegelman, Towards an Integrated Theory of Intellectual Property, 88 VA. L. REv. 1455 (2002) (noting the integration and simultaneous use of patents and trademarks in business practice and calling for a new theory of intellectual property to address the integration of different types of intellectual property).

376. Robert Goldschemer, Licensing AND tHe ART OF Technology Management LAW, TACTICS, FORMS $\S 6.2$ (2002).

377. See Microsoft Corp. v. Liu, No. 1:06-CV-1352-JOF, 2007 WL 4125753, at*3 (N.D. Ga. Oct. 31, 2007) (listing the certificates of copyright registrations for some of Microsoft Window software programs, such as: "(1) TX 4-905-936 (Office 2000 Pro); (2) TX 4-905-950 (Access 2000); (3) TX 4-905-949 (Excel 2000); (4) TX 4-906-019 (Outlook 2000); (5) TX 4-905-952 (PowerPoint 2000); (6) TX 4-905-951 (Word 2000); (7) TX 4-905-937 (Publisher 2000); (8) TX 4-309-301 (FrontPage 2000); and (9) TX 4-899-117 (PhotoDraw 2000)").

378. See generally Mark F. Radcliffe \& Nels R. Nelsen, Code to Code: Perfecting Security Interests in Copyrights: The Confusion Contimues, 8 AM. BANKR. INST. L. REV. 8 (1997) (analogizing a computer software program to a layer cake, each layer representing a "new version or revision of the software ... protected by a separate copyright").

379. See Benjamin J. Kormos, Giving Frankenstein a Soul: Imposing Patentee Obligations, 21 INTELL. PRoP. J. 309, 341 (2009) (reporting that, "[a]s of 2007, Microsoft held more than 6,000 software patents").

380. See Robert W. Gomulkiewicz, Conditions and Covenants in License Contracts: Tales from a Test of the Artistic License, 17 Tex. INTELL. PROP. L.J. 335, 338 (2009) (observing that Microsoft and other software companies rely on trade secret protection afforded to software programs distributed in binary form).

381. Microsoft brought action against others for using its well-known Windows trademark. See Microsoft Corp. v. Lindows.com Inc., No. C01-2115C, 2002 WL 31499324, at *1 (W.D. Wash. Mar. 15, 2002).

382. See Microsoft Corp. v. Silver Star Micro, Inc., No. 1:06-cv-1350-WSD, 2008 WL 115006 , at $* 12$ (N.D. Ga. Jan. 9, 2008) (listing the various trademark registrations for Microsoft "flag" logos in a trademark infringement case).

383. See generally Pharmaceutical Patents: The Value of Pharmaceutical Patents \& Strong Intellectual Property Protection, INNOVATION.ORG, http://www.innovation.org/documents/File/Pharmaceutical_Patents.pdf (last visited Oct. 24, 2010).
384. See
generally
Trade
Secrets
Litigation,
ORRICK, 
they rely on copyright, trade dress, and trademark protections for their various advertising campaigns. Also, to market and sell their drugs, the companies will use trademarks along with pamphlets and instruction. On a particular drug, patents, copyrights, trade secrets, and trademark rights are bundled, as the drug companies aggressively seek protection in all four intellectual property doctrines for their products. ${ }^{385}$

The bundling phenomenon raises the question: how should a particular transaction involving integrated intellectual property be treated for tax purposes under a tax regime that maintains distinct rules for different types of intellectual property? An appropriate analytical framework is needed for revising and crafting tax legislation governing intellectual property, one that considers not only intellectual property goals but also the integrated nature of intellectual property protections in business.

\section{CONCLUSION}

The modern federal tax code does not adequately support contemporary intellectual property policies and the realities of today's economy. It does not ideally support the innovation goals of the intellectual property system. And it does not adequately recognize the evolution of intellectual property, the emergence of new intellectual property forms, or modern intellectual property practices and trends, such as the integration and bundling of different types of intellectual property in business today. A study of the historical development of the intellectual property tax regime reveals causes for the current dissonance between the tax code and intellectual property. As this Article establishes, the vast majority of the specific tax rules governing intellectual property were designed to enhance tax efficiency by resolving procedural dissonance that occurred when traditional principles of taxation were used to resolve early tax disputes. But the absence of an appropriate legal framework for intellectual property tax legislation - one that considers optimal harmonization with the intellectual property scheme - has resulted in a tax code that is fundamentally flawed. Moving forward, an appropriate legal framework is needed for tax rules; one that recognizes that tax law, as well as intellectual property law, is central to innovation.

\footnotetext{
http://www.orrick.com/practices/intellectual_property/tradesecrets.asp (last visited Oct. 24, 2010).

385. See, e.g., Medication Guide, Nucynta $\mathrm{http} / /$ www nucynta.com/sites/all/themes/nucynta/pdf/nucynta-medication-guide.pdf.

(2009),
} 